\title{
التطورات الاقتصادية المعاصرة واثرها على أحكام القانون الجنائى
}

\author{
shel \\ أ.د / محمد عيد الغريب \\ أستاذ القانون الجنائى
}

كليتتالحقوق - جامعت المنصورة 


\section{هقدمة}

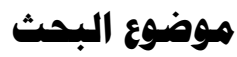

من الطبيعى أن يكون للتحولات الاقتصادية المعاصرة ، نتيجة اتجـاه غالبيـة

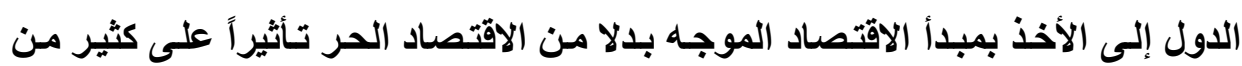

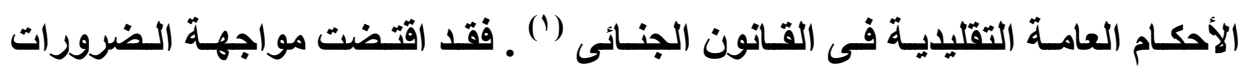
الجديدة التى اهتم بها المشرع الاقتصادى ، أن يتوافق القانون الجنائى معها ، باعتباره وسيلة حماية المصالح الاقتصادية الجماعية .

و الواقع أن دراسـة تأثثير التطورات الاقتصادية على القـانون الجنـائى ، لقيت

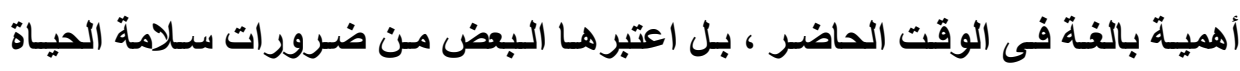

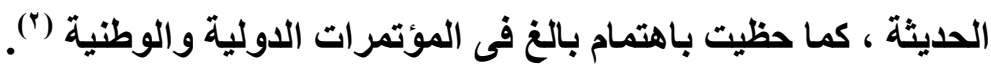
ويلاحظ أن تأثير التطورات الاقتصادية على القانون الجنائى لم يقف عند حد

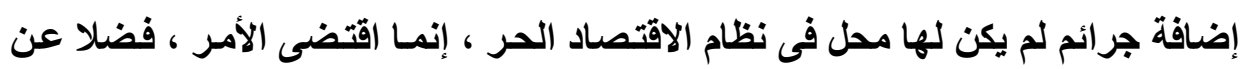

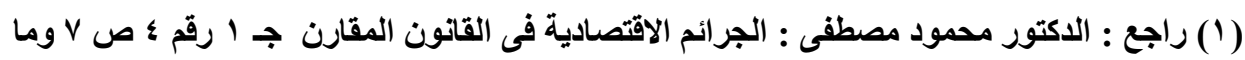

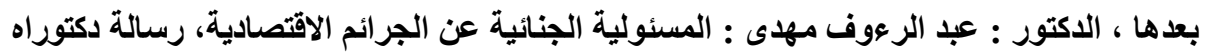

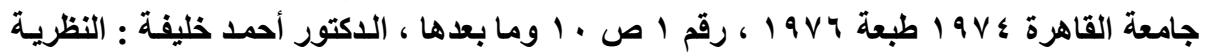

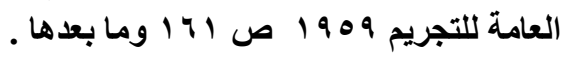

Vitu ( A. ) : Reglementation des changes en Droit pénal, in le contrôle des changes, Paris 1955, P. 74.

$$
\text { (Y) راجع فى ذلك : الدكتور عبد الرعوف المهذى : المرجع السابق رقم Y ص سا وما بعدها . }
$$


ذلك ، الخروج عن كثير من الأحكام العامة التقليدية فى قانون العقوبـات ، ممـا أدى إلى زعزعة المبادئ العامة فى القانون الجنائى.

وظهر ذلتك فى نـواح متعددة مـن أحكـام الجريمـة الاقتصادية ، فشملت مبـدأ

شرعية الجرائم والعقوبات ، وأركان الجريمة كلها، وقواعد الإجراعات الجنائية الخاصة بها ، والفصل بين السلطات القضائية والإدارية ، وشخصية العقوبات ، فقد خضعت هذه النواحى جميعها لتحولات خطيرة عن المبادئ الأساسية .

ويمكن القول ـ بحق ـ إنه على أثر هذه التطورات ، ظهر فرع جليد من فروع القـانون ، هو القـانون الاقتصادى (') ـ وهو مـا أدى إلى ظهور مـا يسمى " بقـانون العقوبات الاقتصـادى " (ץ) . وهو أوسـع مجـالا من قـانون العقوبـات بمعنـاه التقليدى ، والأى تقصر نصوصه عن استيعاب كافة التطورات الاقتصادية فى الدولة .

ويثـار التساؤل حول مستقبل قانون العقوبـات الاقتصادى ، وهل سيظل لهذا القانون دوره أم أن الأهمية المعقدة عليه ستزول بزوال الظروف التى اقتضت وجوده؟ ومن ثم يعود لقانون العقوبات دوره فى حماية المجتمع، وعلى ذلك فإن مستقبل قانون العقوبات الاقتصادى يثير التساؤل حول مستقبل قانون العقوبات بأكمله ، فالقانون الذى

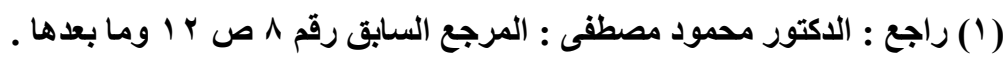

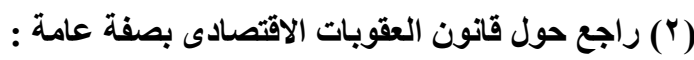

Vouin ( R. ) : Le droit Pénal économique de la France, Rev. int. dr. Pén. 1953, P. 423 ets. Léaute ( J. ): Rapport général sur les infractions économiques, Trav. De L'asso H. Capitant, T. XIII, 1963. P. 611 et s.; Merle et Vitu : Traité de. Droit Pénal, Special, par Vitu, T. 1, 1982 , No. 736 ets., P. 590 ets. 
وضع بالأمس ، يخضع لتطورات فى الوقت الحاضر ، فمـا هو الاتجـاه الذى يتجهه إليه

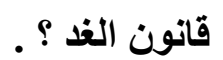

الواقع أن زوال الظروف التى اقتضت وجود قانون العقوبات الاقتصادى لا تؤدى

إلى زواله ، ذلك أن سلطة الدولة فى مجال الاقتصاد تتجهـ دائمـا إلى التوسـع ، وهو مـا يقتضى صــدور تـشريعات متعـددة لتوجيـه الاقتـــاد ، ولا سـيمـا فـى مجــال التنميـة الاجتماعية ـ وبذلك يؤدى قانون العقوبات الاقتصادى دوره إلى جانب قانون العقوبـات باعتباره فرعا متميز|(') . وقد اقتضى ذلك تعديلا فى الأحكام العامة التقليدية فى القانون

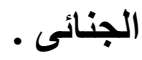

ولذلك رأينـا قبل البحث فى تـأثير التطورات الاقتصادية على احكام القـانون

الجنـائى ، أن نعرض أولا لظهور النظـام العـام الاقتصادى واثره فى ظهور قـانون العقوبـات الاقتصادى ، ومظـاهر هذا النظـام العـام الاقتصادى ، والخصائص المميزة للنظام العام الاقتصادى فى قانون العقوبات.

ومن ناحية اخرى بيان تعريف الجريمة الاقتصادية ، والتفسير الذى يعطى لها ، الذى أدى الى اتساع مجال النظام العام الاقتصادى فى قانون العقوبـات () ـ ولذلك فِان

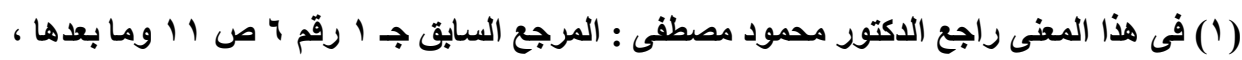

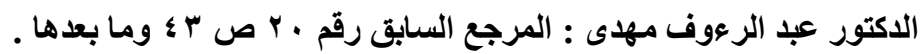

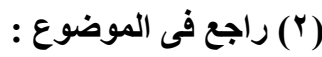

Léauté ( J. ) : les infractions économiques, Cinquiémes journées juridiques, Franco-yougoslaves, Paris, Nancy, Strasnourg, 23-28 mai 1960, publié in journés juridiques de la société de la législation comparé, ed. Cujas 1968, P. 109 ets. ; vivoda ( M. ) : Délits $=$ 
مجال النظـام العـام الاقتصادى ومضمونه يختلف بـاختلاف السياسة الاقتصادية التى

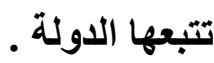

أما عن تأثير التطورات الاقتصادية على احكام القـانون الجنائى فانهه لـ يقتصر

على الخـروج عن المبـادئ الأسـاسية فـى قـانون العقوبـات ، بـل وقواعد الإجـراعات الجنائية كذلك ، فقد شمل المبادئ الأساسية فى التجريم والمسئولية الجنائية ، كما امتـ إلى إجراعات الدعوى الجنائية والحكم والجزاء(') .

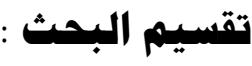
وعلى هلى ما تتلدم رأينا أن نقسم البحث الى فصليز :

نعرض فى الفصل الاول للنظام العـام الاقتصادى ، وبيـان مظاهر هذا النظام ، والخصائص المميزة للنظام العام الاقتصادى فى قانون العقوبات فى مبحث اول ، ثم نعرض لتعريف الجريمة الاقتصادية ، و أثرها فى اتساع مجال النظام العام الاقتصادى ، ف مبحث ثنان

وفى الفصل الثانى نعرض لـصور الخروج عن الاحكـام العامـة التقليديـة فى القـانون الجنـائى ـ وسـنتناول هـذه التحولات التى ظهرت فـى المبـادئ الأساسية فـى القـانون الجنـائى فى ثُلاثـة مباحـث : الأول نخصـصه لأوجـه الخـروج عـن المبـادئ

économiques en Droit pénal yougoslave, in journés précité. P. 83 ets.

Léauté ( J. ) : Rapport Précité, P. 110 ets.; Delmas Marty ( Mireille ) :Rendre le droit Pénal des affaires Plus dissuasif, Rev. Dr. Pén. Et de Crim. 1981, P. 301, Merle et Vitu : OP. Cit., No. 744, P. 596. 
الأساسية فى قانون العقوبات ، والثانى لأوجه الخروج عن أحكام الإجراءات الجنائية ،

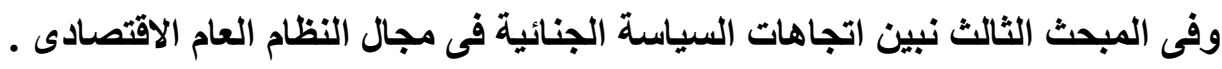

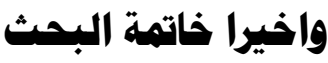

وبعد : حاولت فى هذا البحث إبراز التطورات الاقتصادية المعاصرة واثرهـا

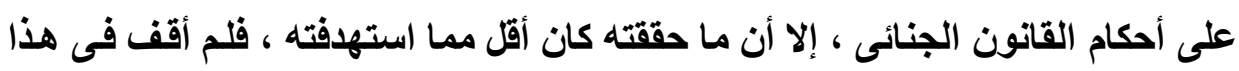

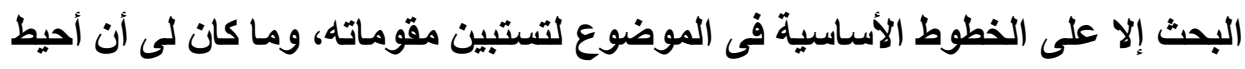

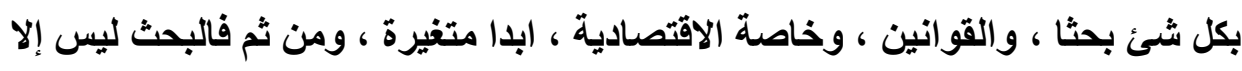

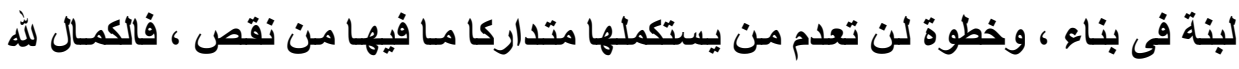

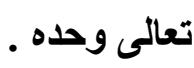




\title{
الفصل الاول

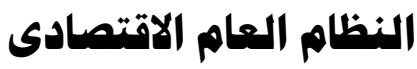

\section{المبحث الاول}

ظهور النظام العام الاقتصادى

\begin{abstract}
قانون العقوبات الاتتصادى :
كان لظهور نظام الاقتصاد الموجهه - Dirigisme éconimique - ، وتطوره

فى الوقت المعاصر أن ازدهر فرع جديد من قـانون العقوبـات ، هو قانون العقوبـات

الاقتصادى ، وأصبحت له صفة الدوام فى كثير من الدول (')
\end{abstract}

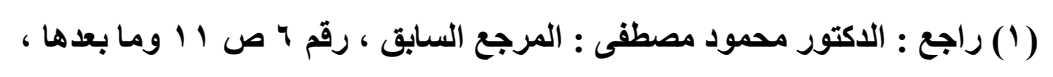

levasseur ( G. ) : le droit pénal économique, cours de doctrat, U. de Caire 1960 - 1961 ; Mazard ( J. ) : Aspect du droit économique francais, Autonmie et orthodoxeé, Rev. Sc. Crim. 1957, P. 19 ets. ; leauté (J.) : Rapport sur les infractions économiques op.cit.p.617 ets . levasseur (G.) : Rapport général, , in journeés de Paris et Montepllier, le rôle du juge en presence des problémes économiques, in Trav. De l'ass. H. capitant, T. XXII, 1970, P. 36 ets.

ويطلق البعض على قانون العقوبات الاقتصادى اسم " قانون العقوبات الاقتصادى والمالى" ، أو "

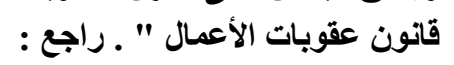

Janssens ( E. ) : le droit pénal économique, Rev. de. Pen. Crim. 1967 1968, P. 229 ets

$=$ 


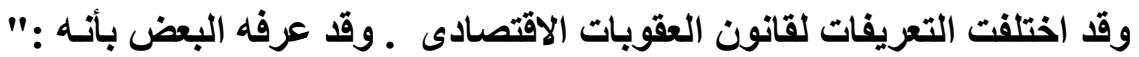
فرع من القاتون الجنائى يحدد التجريم والعقوبات ، يكفل توقيع الجزاعات على مخالفة القواعد الاقتصادية التى ينظمها القانون ، ويعبارة أخرى الاعتداءات التى تمس النظام الاقتصادى الذى أنشأته السياسة الاقتصادية للاولة " (') ـ كمـا عرفه البعض الآخر بأنه " مجموعة القواعد القانونيـة التى تجرم تصرفات الأفراد أو الأشخاص المعنويـة والتى تلحق ضررا أو تهدد السياسة الاجتماعية والاقتصادية لاولة معينة " (†) .

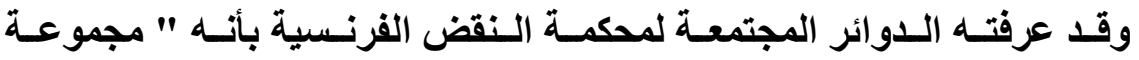
النصوص التى تنظم إنتاج وتوزيع واستهلاك وتداول السلع والخدمات " (") . ولم يتردد البعض حديثا فى القول أن فكرة " قانون العقوبات الاقتصادى " ليس لها أى معنى فى إطـار القـانون الوضسعى الحسالى ـ وأنـه من المستحيل إعطاء تعريف محدد لقـانون العقوبـات الإقتصادى لإقامـة نظام قاعدى لتبرير خضوع بعض الجرائم

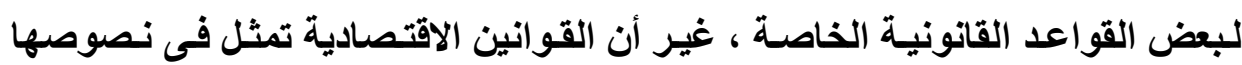

\section{غير أن تفضيل أى من هذه التسميات ليس له فى ذاته أى نتائج قانونية مباشرة .}

$$
\text { : أنظر }
$$

Bosly ( H.D. ) : et Spreutels ( J.P. ) : Aspects actuels du droit penal des affaires en belgique, Rev. de dr. Pen. Et du crim. 1983, No. 1, P. 28.

Levasseur ( G. ) : cours cit., P. 16.

Zlataric ( B. ) : " le droit pénal social et économique en régard spécialement à la législation yougoslave “, Rev. int. de dr. Pén. No. 4, 1953, P. 1021.

Cass., ch. Réunies, leravr. 1949, J.C.P. 1949, II, 5033 note leroy. 
الجنائية بعض الخصوصية بالمقابلـة لقانون العقوبـات العـام ، إلا أنها لا تتعلق بنظام

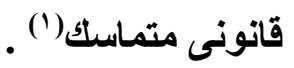

\section{العلاقة بين القانون الاقتصادى وقانون العقوبات الاقتصادى:}

عرف القانون الاقتصادى ، بمفهومـه الواسـع ، بأنسه " قانون التظظيم والتنمية

الاقتصادية الصادرة عن الدولة وعن الأفراد ، أو التنسيق بين هذه وتلكك " ـ أى أنـه "

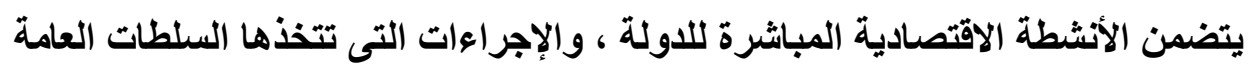

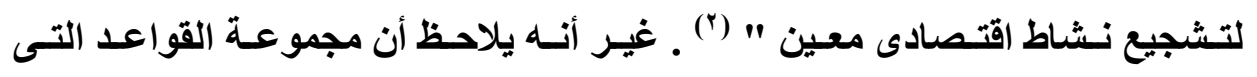

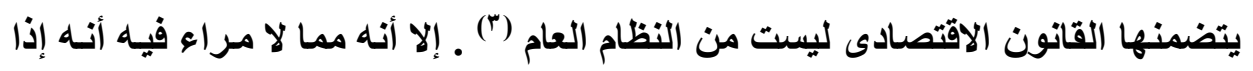

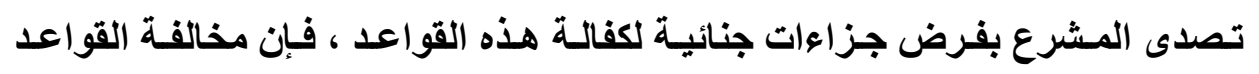
المشمولة بالجزاء الجنائى هو الأى يعد مساسا بالنظام العام الاقتصادى للاولة (؛) . وينـاء على ذلك ، فبإن قانون العقوبـات الاقتصادى هو الذى يحمى بجزاع|ته الجنائية قواعد القانون الاقتصادى ـ أو كما عبر عنه المؤتمر الدولى السادس لقانون العقوبات المنعقد فى روما سنة به 9 ، ، فإنـه يتكون من النصوص الجزائية للقانون

Bosly et Spreutels : Op. Cit., P. 38.

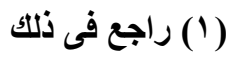

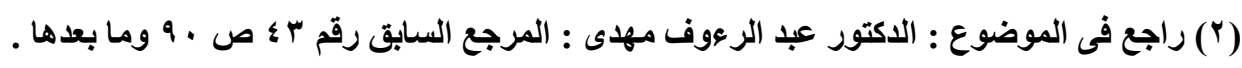

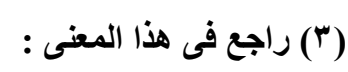

Observastions Savatier : chron. D. 1965, P. 38, 1 er. Col.

: (\&)

Costa ( J.C. ) : - La jurisprudence de la chambre criminelle et L'élabration d'un ordre Public économique et social, in la chmbre criminelle et sa jurisprudence ; Recueil d'etudes en hommage à La mémoire de Maurice Patin, Cujas 1965. , P. 65 ets. 
الاجتماعى الاقتصادى ، وبعبارة أخرى هو القانون الذى يعاقب على المساس بالنظام العام الاقتصادى للاولة " (')

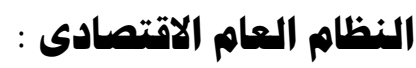

عرف النظام العام الاقتصادى بأنه " النظام الاقتصادى الأى يرنكز عليه مجتمع معين ، فهو البنيان الذى يقوم عليه المجتمع " () ـ وعلى ذلتك يختلف النظام العـام الاقتصادى فى الدول بـاختلاف النظام السياسى والاقتصادى والاجتمـاعى الذى تتبعه

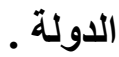

ويبدو هذا الاختلاف واضحا بين الدول الاشتراكية ، التى تأخذ بنظام الاقتصاد الموجه ، والدول الرأسمالية ، التى تأخذ بنظام الاقتصاد الحر ـ كما يبدو الاختلاف أيضا بين قوانين الدول الاشتراكية ذاتها على ضوء اختلاف نظمها الاقتصادية ، وخاصة فيما يتعلق بمدى سيطرة الاولة على النشاط الاقتصادى وحجم ودور القطاع الخاص فى هذه الاولة ، وكيفية إدارتها للمنشآت الاقتصادية (") .

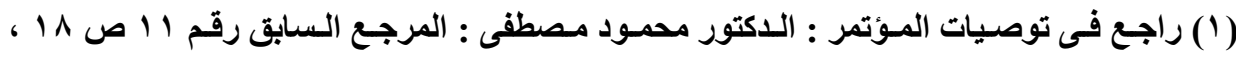

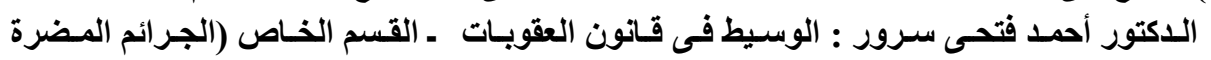

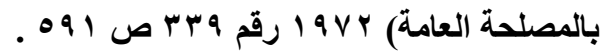

Merle et Vitu : Op. Cit., Dr. Pén. Sp., No. 735, P. 588 ets

Farjat ( M.M.G. ) : l'ordre Publique éconimique Thése, Dijon, 1963. P. 30. (r) الدكتور محمود مصطفى : المرجع السابق رقم ؛ ص V وما بعدها ، الدكتور أحمد فتحى سرور :

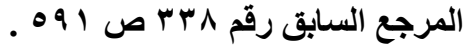




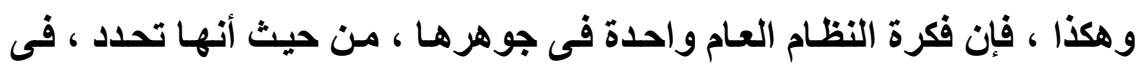
وقت معين من تطور الهيئة الاجتماعية ، الأولويات بين القواعد القانونية ، غير أنها

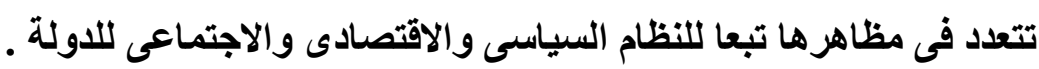
وفى ضوء هذا التقسيم ، قسم النظام العام الاقتصادى إلى نوعين مختلفين :

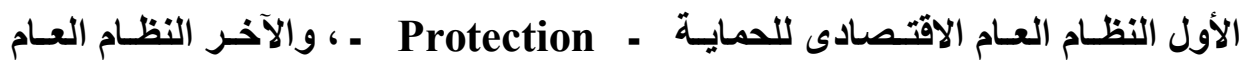

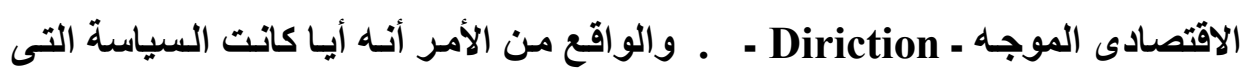

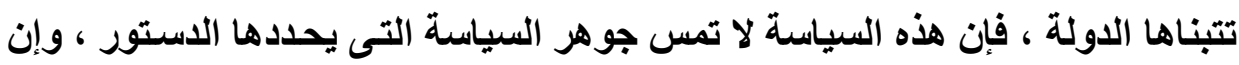

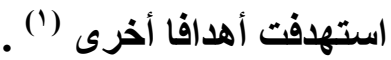




\section{المبحث الثانى \\ هظاهر النظام العام الاقتصادى}

كان أول مظهر للنظام العام الاقتصادى فى شكل نظام الحماية ، ثم تطور الأمر

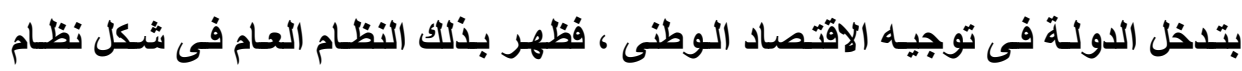

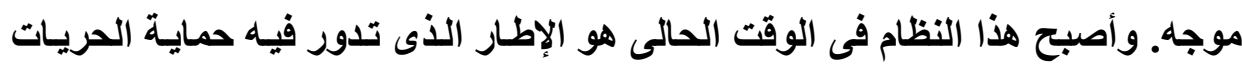

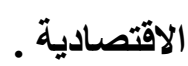

ولذلك نتناول أولا النظام العام الاقتصادى الموجه ، ثم النظام العام الاقتصادى

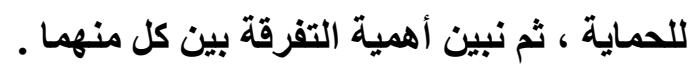
أولا : النظام العام الاقتصادى الموجه : يرتكز النظام العام الاقتصادى الموجه على المساهمة فى توجيه معين للاقتصاد

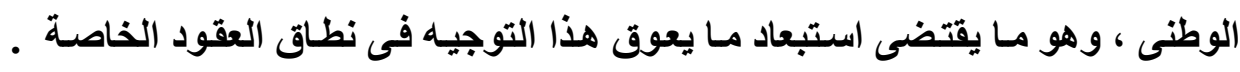

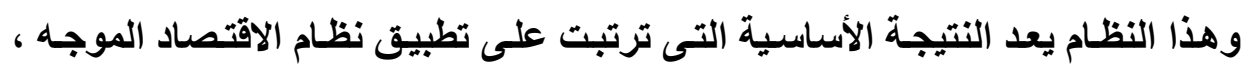
وبصفة خاصة منذ انتهاء الحرب العالمية الأخيرة ، التى ضاعفت من حدة الاهتمام لاى الدول بالتدخل فى مختلف المجالات الاقتصادية بقصد توجيهها نحو تحقيق مصلحة المجتمع . و هكذا استعادت الاولة الموجهة - Etat dirigiste ـ من الأفراد ذلك الجزء من

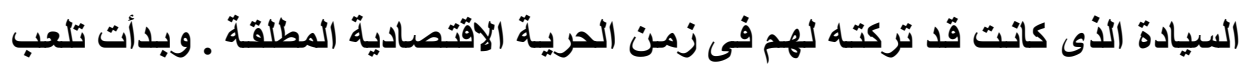

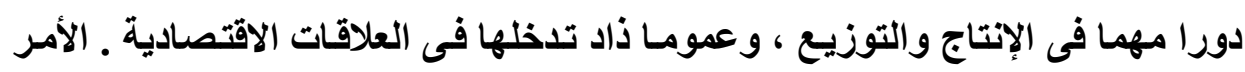


الأى ترتب عليه ازديـاد مجـال القواعد العامـة الآمرة التى تتعلق بتنظيم وحمايـة هذا التتخل فى مختلف المجالات الاقتصادية(') ـ فالدولة تتدخل اليوم فى الاقتصاد ، ليس بصفتها الحكم بين القوى الاقتصادية المتنافسة فحسب ، بـل التدخل بوصفها رب عمل فى بعض القطاعـات الاقتصادية العامـة فى الإنتاج القومى ، إذ يهمها بصفة مباشرة حسن سـير الاقتصـاد الـوطنى ، ولأنهـا تـضطلع ، بـصفة خاصسة ، بتحديــ الأولويـات الاقتصادية للبلاد ، عن طريق الخطة ، بغية الوصول إلى التطور الاجتمـاعى وضمان

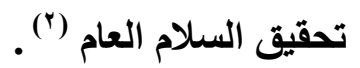

والواقع أن تلخل الدولة بوصفها رب العمل لم يعد اليوم محلا للهجوم، حتى من قبل أعداء هذه الفكرة الظاهرين ، حيث أنهم لجـأوا إلى الاستعانة بمساعدة الدولـة ، خاصة فى فترات الأزمات ـ فقد أظهرت الاضطر ابات التى حدثت فى الحياة الاقتصادية ، لمعظم البلدان ، الحاجة لتدخل أكبر من جاتب الدولة فى الاقتصاد ، وبصفة خاصـة فى

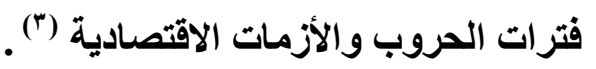
غير أن من أخطر القيود على الحريـة الاقتصادية ، نتيجة الأخذ بالنظـام العام الاقتصادى الموجه ، ظهر عندما تـخل المشرع فى مجـال تكوين العقود ، وقد استمد النظام العام الاقتصادى الموجه قوته تبعا للمفهوم التحكمى لسلطات الدولة فى الشئون

$$
\text { ( ) (1) ) راجع فى ذلك : (1) }
$$

Fonyo ( Antal ) et vermes ( Miklos ) : l'economie et le droit, Aspects de droit pénal, Rapport présenté aux Deuxiémes journeés juridiques franco-hongroies, Paris Ier. Au 5 juin 1970, public in Rev. Sc. Crim. 1974, No. 1, P. 67 ets.

Merle et Vitu : OP. Cit., No. 738, P. 551 
الاقتصادية ، من الاستعانة بإجراءات الضغط الجنائى ، وذلك بازدياد النصوص الجنائية

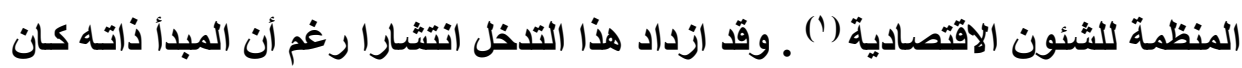

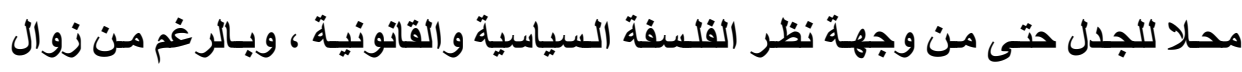

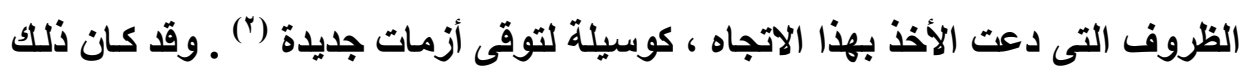

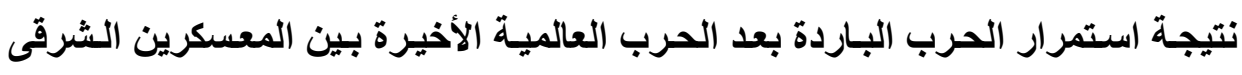

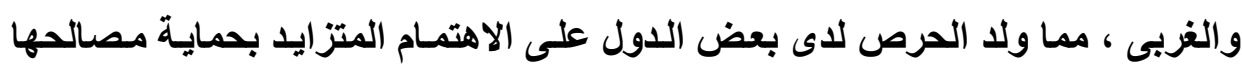

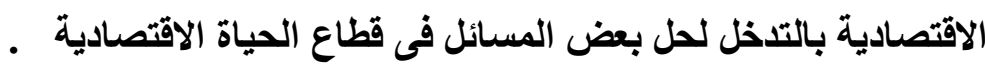

وهكذا يبين أن النظام العام الموجه تزداد أهميته فى ظل النظام الذى تسود فيه فكرة الاقتصاد الموجه ، إذ يترتب على تلدل الدولة فى الشئون الاقتصادية ، بقصد توجيهها نحو مصلحة المجتمع ، ضرورة وضع قواعد قانونية مدعمة بالجزاءات لتنظم وتحمى تلك السياسة الاقتصادية ، ذلك أن المشرع لا يقتصر دوره على التدخل لحماية

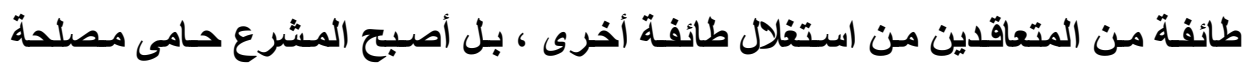

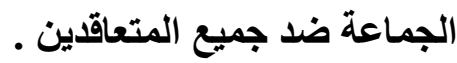
ثانيا : النظام العام الاقتصادى للهماية :

يهدف النظام العام الاقتصادى للحماية إلى حماية الطرف الضعيف اقتصاديا فى

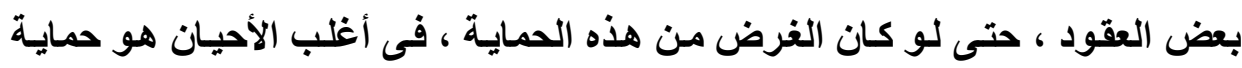

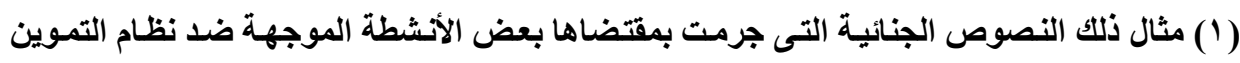

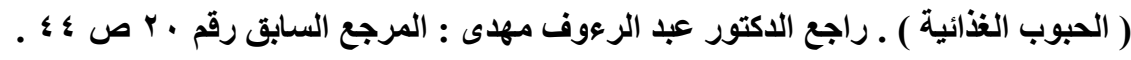
(r)

Fonyo ( A. ) et vermes ( M. ) : Rapport précité, P. 67. 
المصالح الفردية التى يهذف النظام إلى تحقيقها (') ـوهذه الحماية تأخذ شكلا خاصـا ، يختلف عن الحماية التى يقررها قانون العقوبات الذى يحمى النثاط الاقتصادى للأفراد

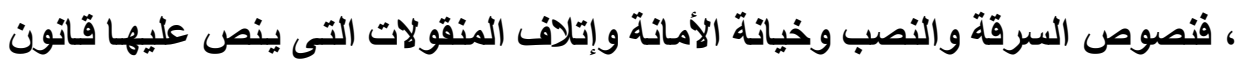

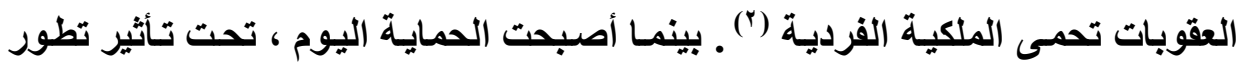
المذاهب الاقتصادية ، تتجه نحو الحماية الجماعية للأفراد ، وهذه الحماية تعد ضرورة

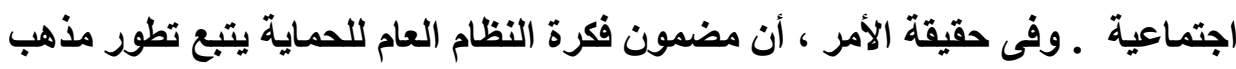

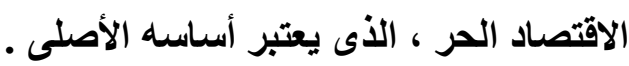

\section{مضمون فكرة النظام العام فى ظل الاقتصاد الصر :}

كان من نتائج المذهب الحر ، على المستوى القانونى ، احترام سلطان الإرادة ،

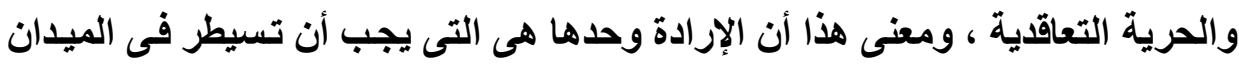
الاقتصادى ، وأن العقود لا تخضع فى تكوينها ، وفى الآثار التى تترتب عليها ، إلا الا

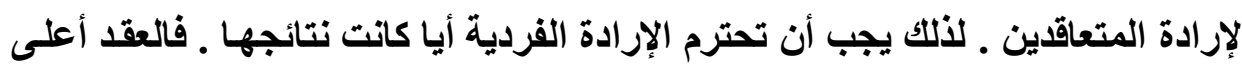
مرتبة من التشريع ـ ذلك أن دور المشرع يكون شبه معدوم فى العلاقات الاقتصادية

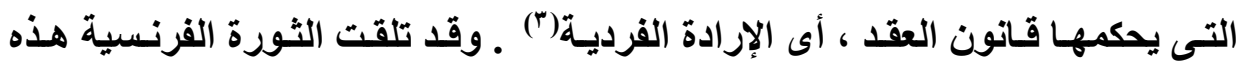

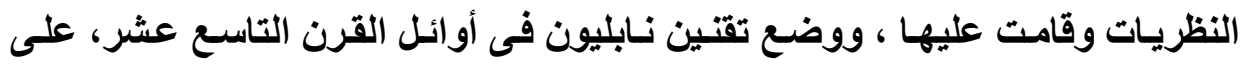
أساس تقديس حرية الفرد والإمعان فى احترام إرادته (؛) .

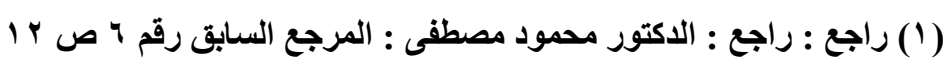

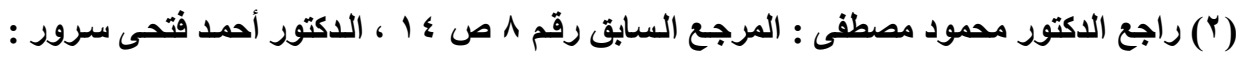

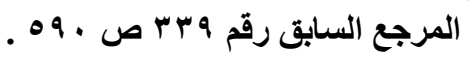

Fonyo ( A. ) et vermes ( M. ) : Op. Cit., P. 67 . 
ولا شكك فى أنه فى ظل مذهب الاقتصاد الحر ، يتولا النظام تلقائيا من حرية دور

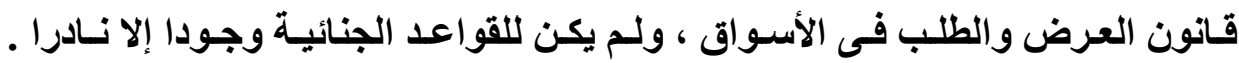

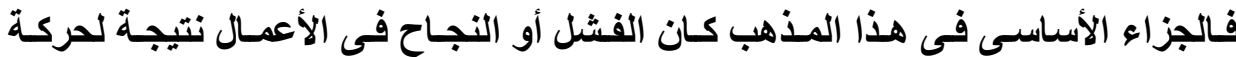

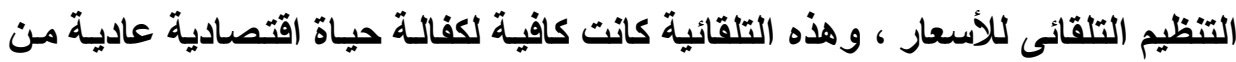
وجهة نظر الرأسمالية الحرة ، وكسان تـذل قـانون العقوبـات ينحصر فـى العقوبـات

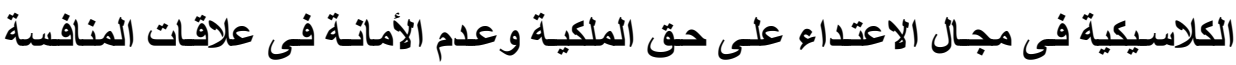

ويلاحظ أن النظام العسام ، فـ هذا العصر لـ يكن يهدف إلا أن يستبعد مـن

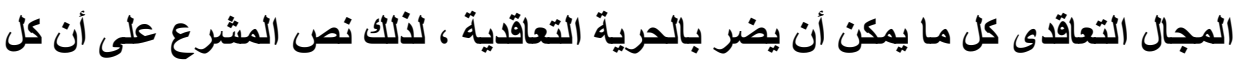

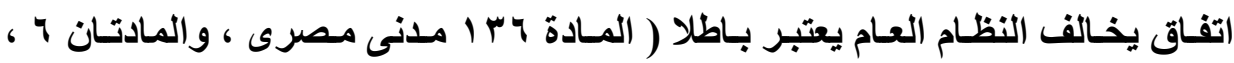

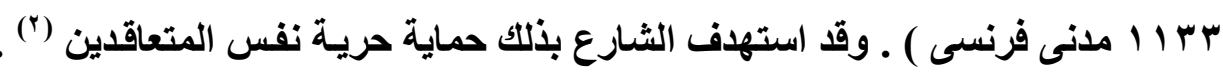
ولذلك كانت تشريعات الدول ذات النظام الرأسمالى تأخذ بحسب الأصل بمبدأ الحريـة

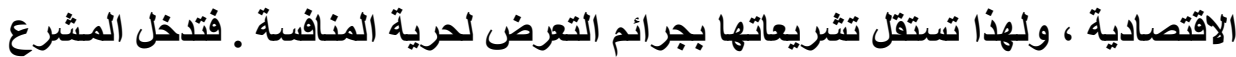

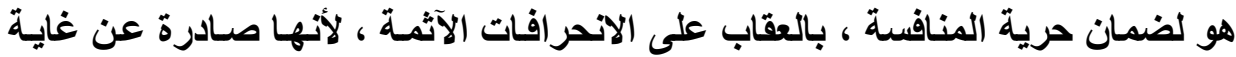

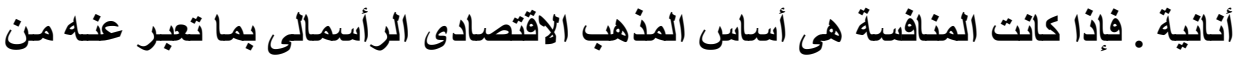

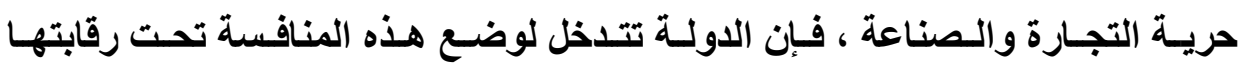

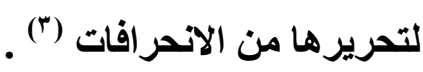

Costa ( J.L. ) : Op. Cit., P. 92 ets.

(ץ) راجع : الاكتور فتحى عبد الرحيم عبد الله: الغناصر المكونة للعقد كمصدر للالتزام فى القانونين

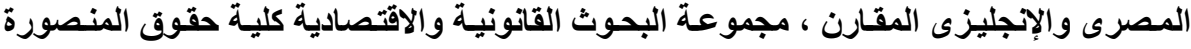

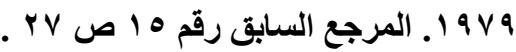

Levasseur : Rapport précité, P. 36

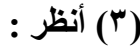




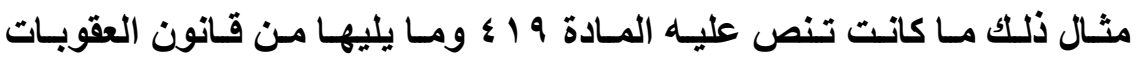

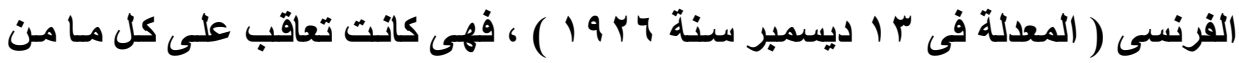

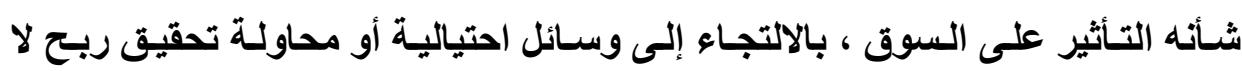

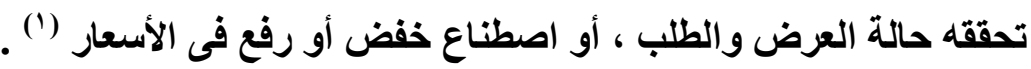
وقد الغيت هذه المادة وحلت محلها المسادة به ــ من قانون اول ديسمبر سنة

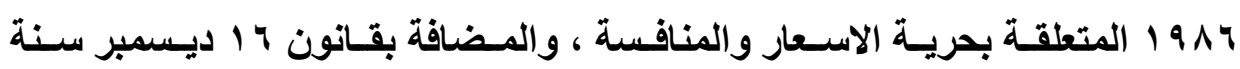

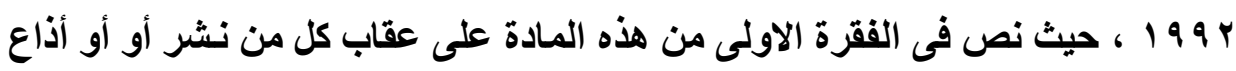
وقاتع أو معلومات كاذبة أو غير حقيقية فى السوق أو سعر سلعة مـا من شـأنها إحداث

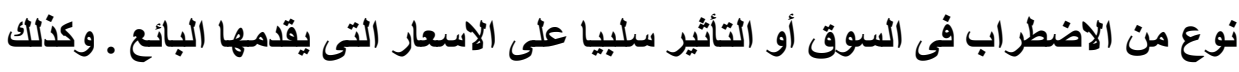

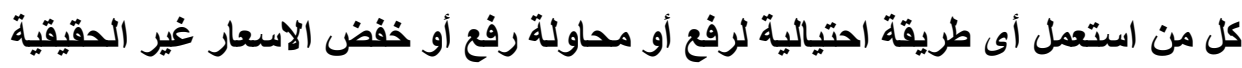

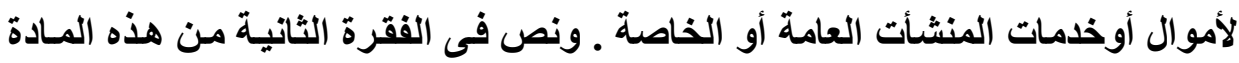

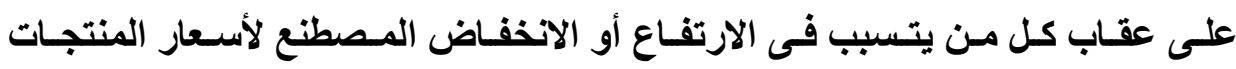
الغذائية. وأيضا نص فى المادة السابعة من قانون أول ديسمبر سنة به 1914 على حظر

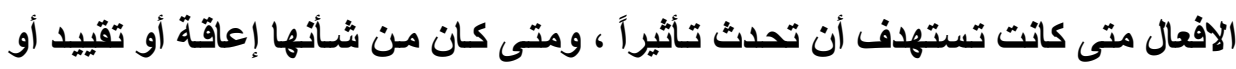

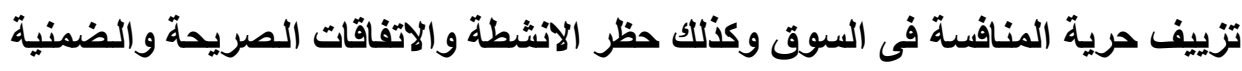

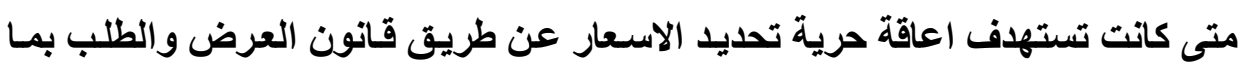
يمكن رفعها أو خفضها صوريا .

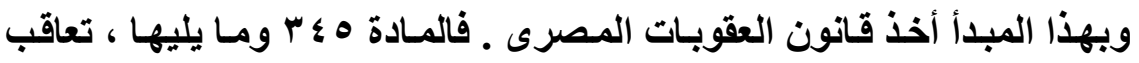

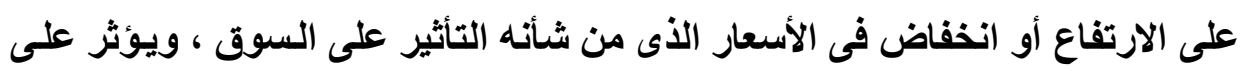

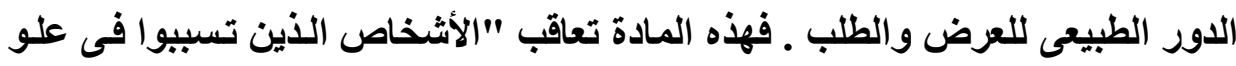


أو انحطاط أسعار الغلال أو بضائع أو بونات أو سندات مالية معدة للتداول عن القيمة

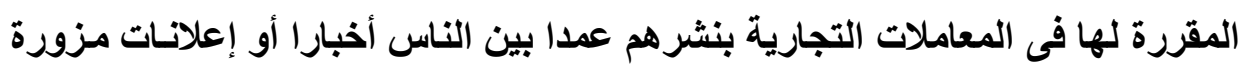

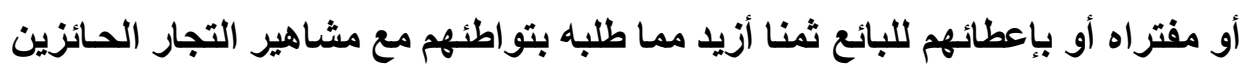

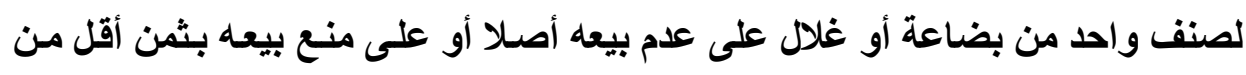

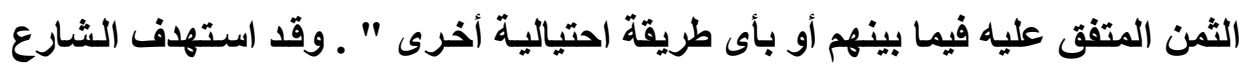

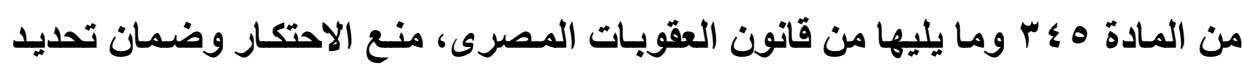

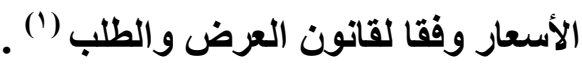

ويلاحظ أن معالجة المشرع المصرى لحمايـة نظام السوق الحر وفقـا لقانون

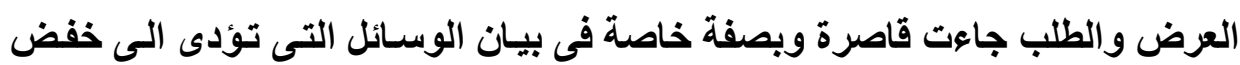

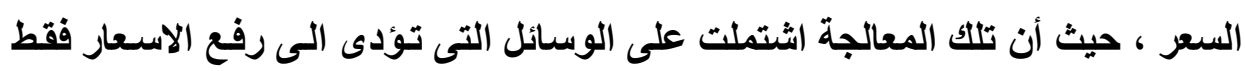

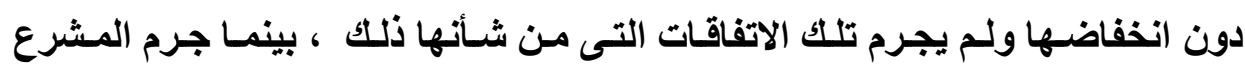

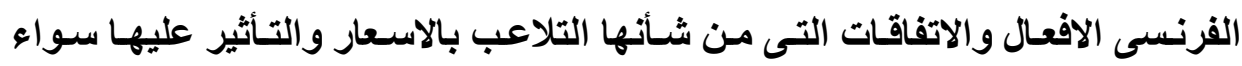

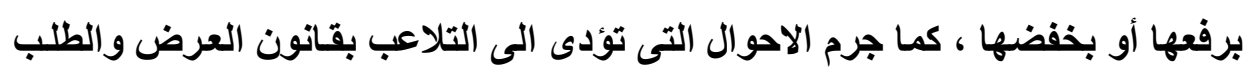

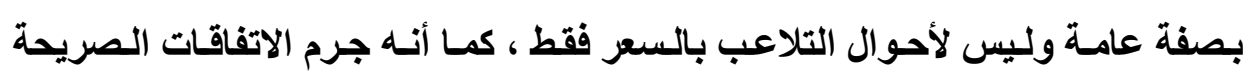

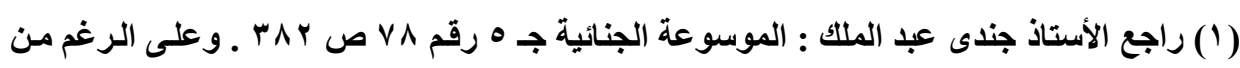

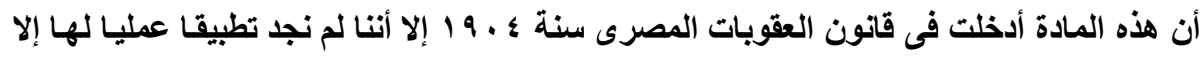

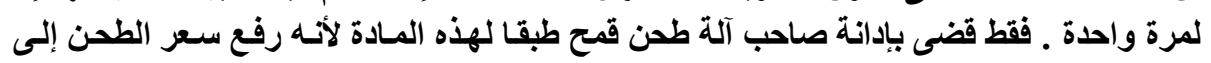

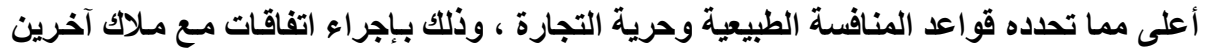

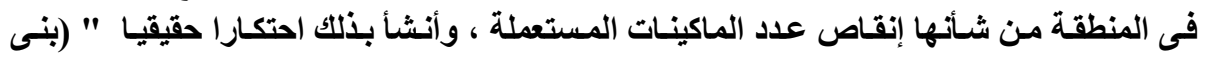

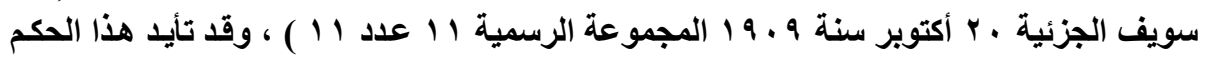

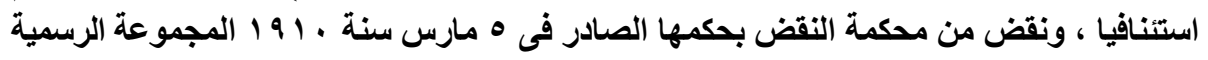

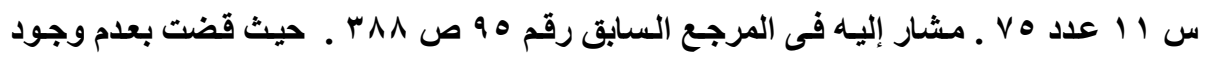

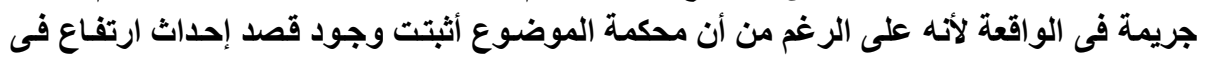

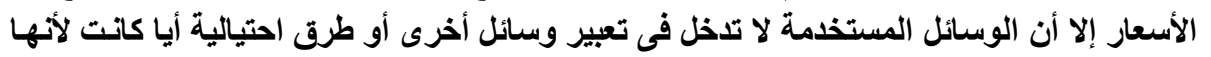

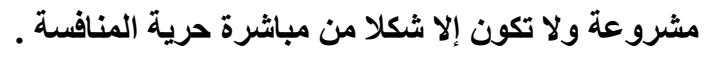


والضمنية التى تؤدى الى التلاعب بالاسعار وكذلكت تجريمـه لرفع أومحاولية رفع أو خفض أسعار المنتجات والخدمات .

\section{هضمون النظام العام فى ظل النظام الحر الحديث :}

لم يدم مفهوم الحريـة على النحو السابق طويلا ، بعد أن تبين أن منح الحريـة للقوى الاقتصادية الكبيرة يؤدى فى الواقع إلى فرض قانونها وشروطها ، وإلى الى استغلال

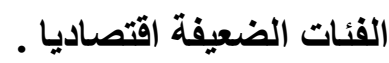

فالنظام الاقتصادى الحر ، بافتراض أن الأفراد متساوون فى علاقاتهر ، أسند

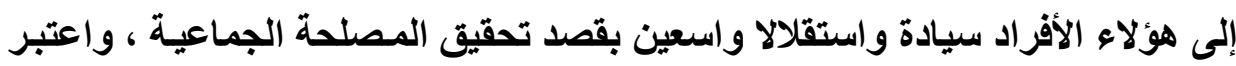

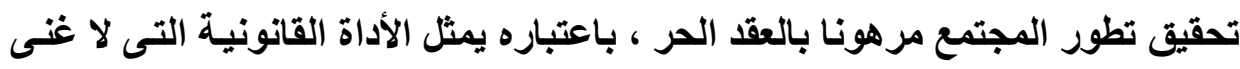
عنها

غير أن التطور والتحول الحديث للمجتمع ، والازدهـار الفكرى والاجتمـاعى فى التي

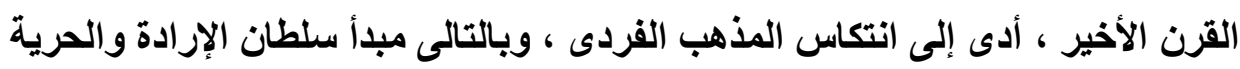

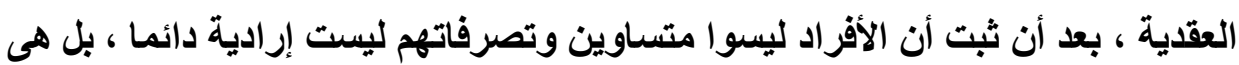

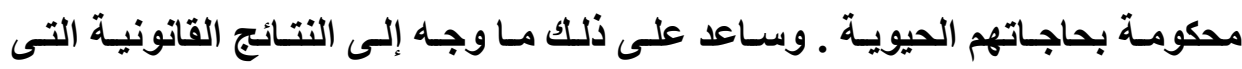

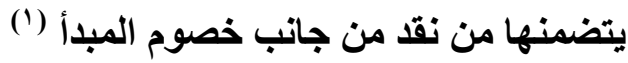
ولذلك حاول أنصار المدرسة التحرريـة الحيثة تصحيح التجاوزات الخطيرة

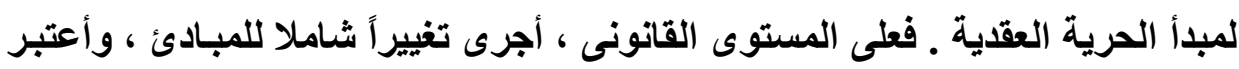
النظام العام كملطف لمبدأ حرية التعاقد .

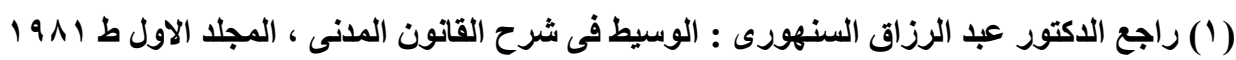

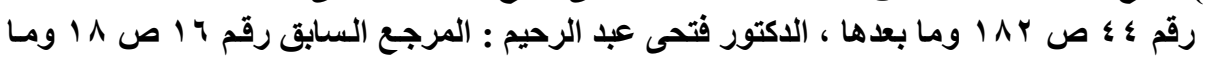




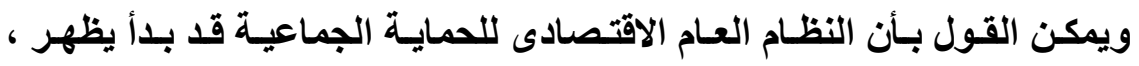

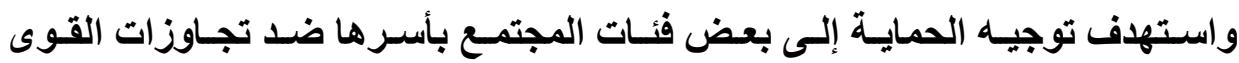

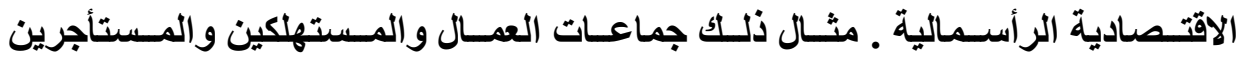
والمزارعين والمستأمنين وصغار المدخرين (') .

ولم يسلم قانون العقوبات الاقتصادى من التأثر بهذه التطورات ، حيث أن أغلب

النصوص التى تكون جوهر النظام العـام الاقتصادى للحمايـة الجماعية معاقبـا عليها

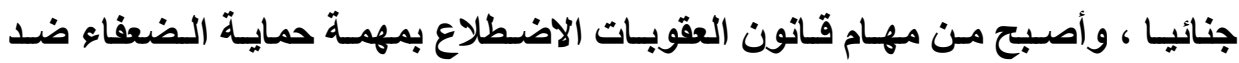
الأقوياء () (ن)

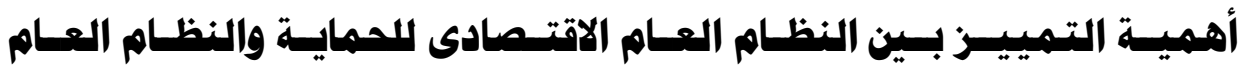

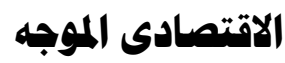

الواقع من الأمر ، أنه فى ظل فكرة النظـام العـام الاقتصـادى للحمايـة الجماعيـة ،

يلاحظ أن التفرقة بين النظام العام الاقتصادى للحماية والنظام العام الاقتصادى الموجه

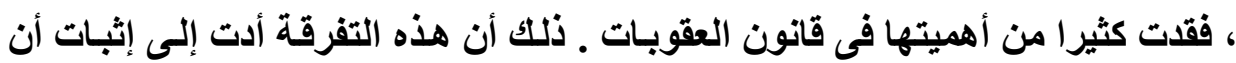
النظام العـام الاقتصادى للحمايـة نفسه قد أخذ يتطور ، على الرغم مـن اتجاهـه نحو

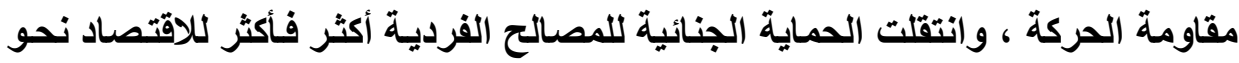

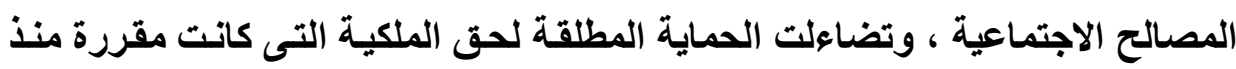

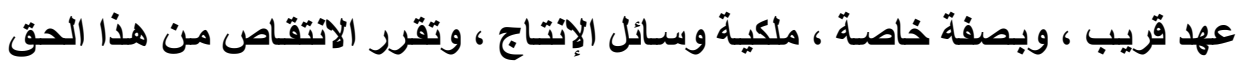

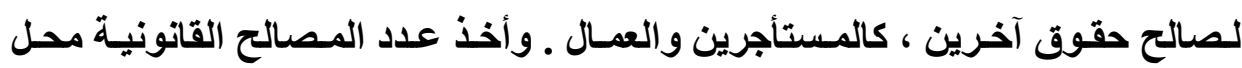

Farjat : Op. Cit., No. 164 et 403.

Ottenhof ( R. ) : le droit Pénal et la Fotrmation du contrat civil, th. Rennes 1970 .., No. 119, P. 114. 
الحماية يتزايد دون توقف ، بحيث تعين أن تتحد المصالح القديمة مع المصالح الجديدة،

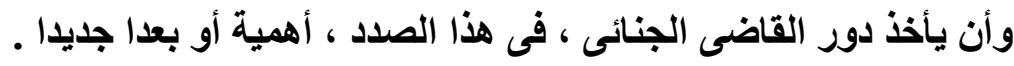

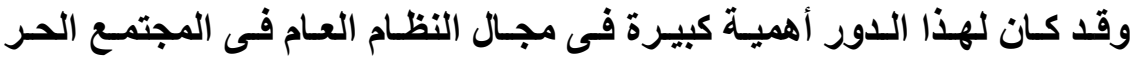

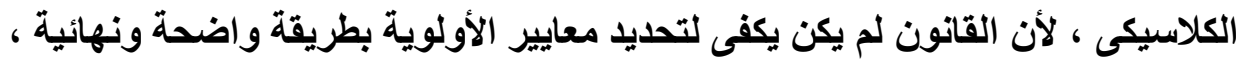

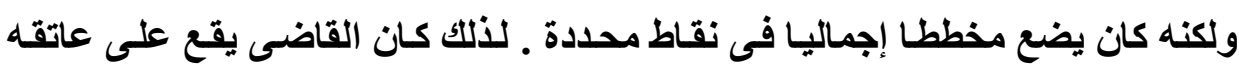
تحديد خط متصل واضح بمناسبة كل حالة على حدة . غير أن دوره أصبح أكثر تعقيدا

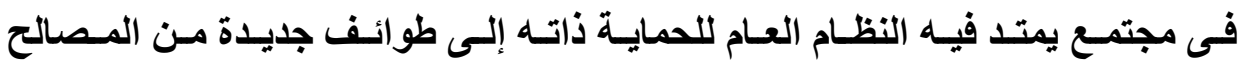
المتعارضة فيما بينها ـ أى نظام عام اقتصادى للحمايـة الجماعية ، المتجه لحماية فئة فئة

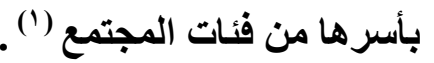
وممـا لا شـك فيـه أن موضسوع النظـام العـام الاقتصادى للحمايـة الجماعيـة ظل

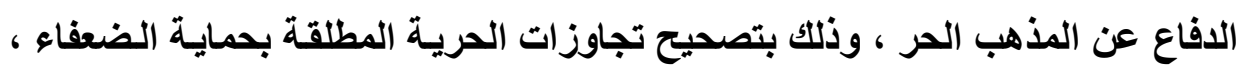
واجته المشرع الجنائى فى ضمان المنافسة الحقيقة الناثئة عن العرض والطلب . غير أنه يلاحظ أن تنظيم المنافسة يهدف فى النهايـة إلى الحصول على أقل الأسعار فى مصلحة المستهلكين (") . كما يهذف أيضا الوصول إلى سياسة عامة تلتميز بثبات الأجور والأسعار ، تقوم على أساس توجيه السياسة النقدية للاولة . ويتضح مما تقام أن النظام العام الاقتصادى فى قانون العقوبات يقوم على نوع من وحدة الهلف ، الذى يظهر بشكل أوضح فى الخصائص العامة لهذا النظام ـ وهو مـا لـأ سنتاوله بالبيان فى المبحث التالى .

Costa ( J. ) : Rapport Précité, P. 108.

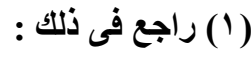

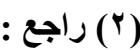

Pirovano ( A. ) : La Concurrence déloyale en droit français, in Marché Concurrence et consomateurs, Rev. int. dr. comp. 1974, P. 471. 


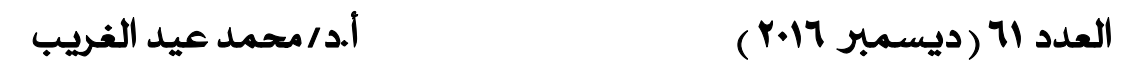

\section{المبحث الثالث \\ الفصائص العامة للنظام العام \\ الاقتصادى فى قانون الهقوبات}

يتميز النظام العام الاقتصادى فى قانون العقوبـات بـأن لـه خصائصه المميزة ،

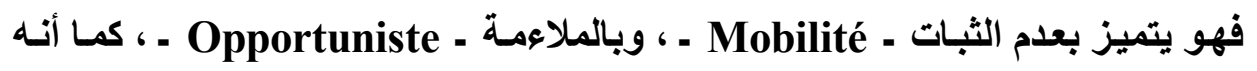

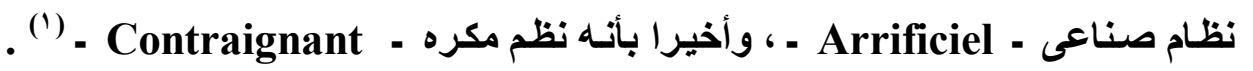
ونتتاول فيما يلى هذه الخصائص بالبيان .

أولا : عدم الثبات :

يتسم النظام العام الاقتصادى فى قانون العقوبات بعدم الثبات والمرونة ـ ذلك أن

نصوص قـانون العقوبـات الاقتصادى متغيرة تبعـا لتغيير الظروف الاقتصادية ، وتبعا لعلاقات القوة بين السلطات الاقتصادية ، والطبقات الاجتماعية ـ وتتفير هذه النصوص مغ كذلك باختلاف النظام الاقتصادى الذى تتبعه الدولة ـومن ثم ليست لها صفة الدوام ولهام والاستقرار والعمومية التى تتحقق للقواعد القانونية الأخرى .

(1) راجع فى عرض هذه الخصائص :

Farjat : Op. Cit., No. 120 ets . ; Mazard ( J. ) : Aspect du Droit économique francais ( Autonomie et orthoxie) , Rev. Sc. Crim. 1957. P. 19 ets. ; Ottenhof ( R. ) : Op. Cit., No. 120, ets., P. 115 ets. 
و الواقع أن قانون العقوبات ، بالرغم من قسوته ، إلا أنها يبدو أكثر توافقا من

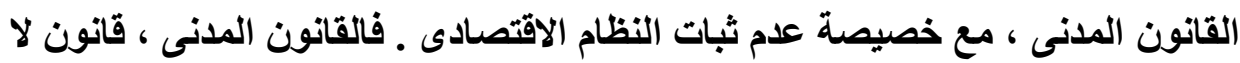

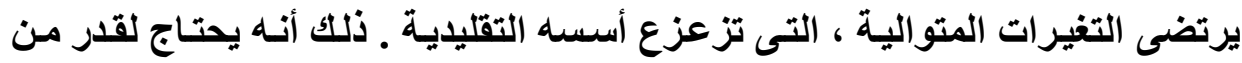

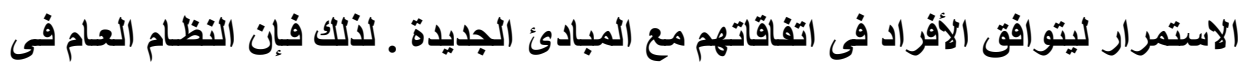

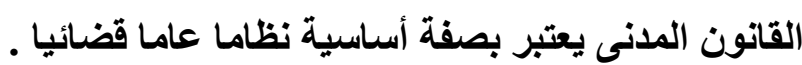
وفى هذا المجال يبدو القاضى المدنى أكثر تحفظـ (') ـ إذ أنه فى سبيل تحديد

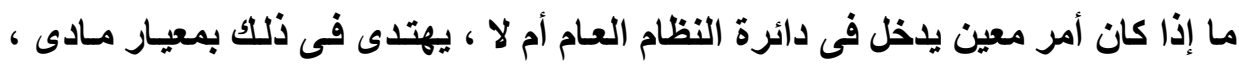

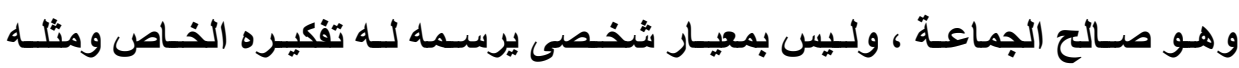
العليا الذاتية (") الجمان خلافا لذلك النظام العام الاقتصادى فى قانون العقوبـات ، فمصدره الوحيد هو الوإ

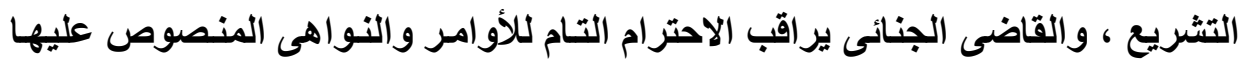

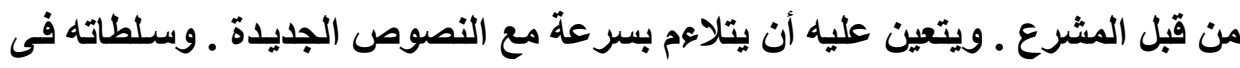
التفسير أيضا أقل اتساعا من سلطات القاضسى المدنى ، فهو إذا أقل محاولية لمقاومـة

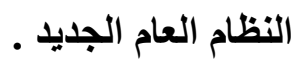
ومن ناحية أخرى ، إن قوة مبدأ " لا يعذر أحد بجهله بالقانون " فى قانون

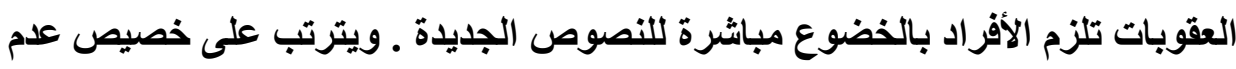

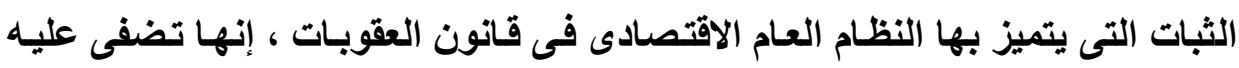
الطابع الثورى - Révolutionnaire

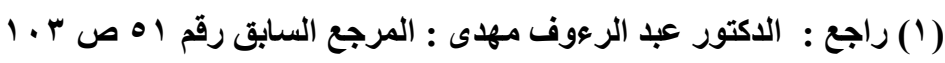

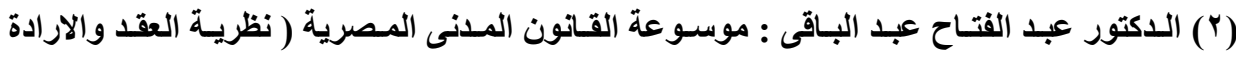

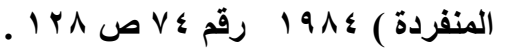

Ottenhof ( R. ) : Op. Cit., No. 120, P.116

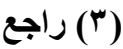




\section{ثانيا : الملاء همة :}

اقتضى اتصاف النظـام العـام الاقتـصادى فى قـانون العقوبـات بخصيصة عدم الثبات ، أنه يتصف كذلك بصفة الملاعمة ـ فهو لا يستتد على أسس ثابتة ، بل يتناولهـ المشرع كثيرا بالتعديل والإلغاء طبقا لمقتضيات ظروف اقتصادية معينة ( ) . غير أنه يلاحظ أن خصيصة الملاعمـة ليست فحسب من فعل المشرع، بل أنها تخضع للظروف التى تحكم اختصاص القاضى الجنائى .

وفى الواقع ، عندما يفصل القاضى المدنى فى مسألة تتعلق بالنظام العـام ، فإنها. يكون فى أغلب الحالات بمناسبة حالة عرضت عليه من قبل الأفراد ، وبالتسلى يتعين

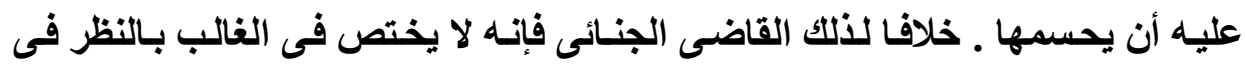

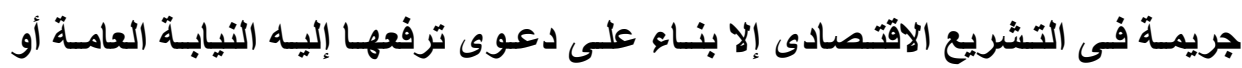
الإدارات المختصة ، صاحبة الاختصاص فى هذا الصدد ، وليس للأفراد فى هذا المجـال أى دور فى تحريك الدعوى الجنائية مباشرة أمسام المحكـة الجنائية ، كمـا سنرى فيمـا

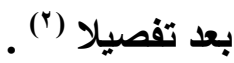
وتبدو خصيصة الملاعمـة للنظـام العـام الاقتصادى فى مبدأ الملاعمـة فى رفع الاعوى الجنائية الأى يجوز للنيابة العامة استعماله ، أو فى حق التصالح الذى تملكه الإدارات فى المجـال الاقتصادى ، ويعتبر النظسم العـام فى قانون العقوبـات ، فى هذا

Savatier ( R. ) : L'order public éconmique, D. 1965, chron P. 37 et specialment P. 41. C. 
الصدد ، سـلاحا مخيفـا بيد الدولـة ـ كمـا سـراه فيهـا بعد(') . ويبرز ذلك فيمـا تصدره

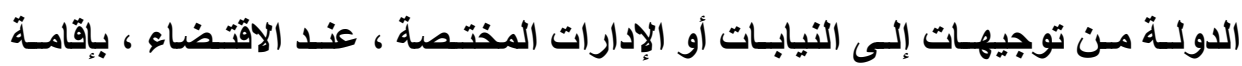

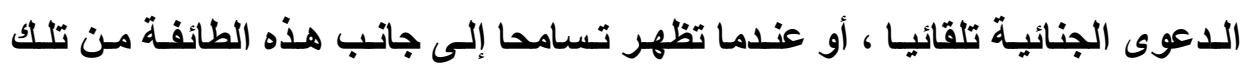
الجرائم ، أو طوائف المجرمين الاقتصاديين ـ على أن تطبيق هذه القواعد من شـأنه أن يربط السياسة الجنائية فى المجال الاقتصادى ، فى بعض الأحيان ، بسياسة قصيرة

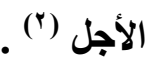

\section{ثالثا : النظام العام الاقتصادى نظام هصطنح :}

يستخلص من خصيصة الملاعمـة التى يتسم بهـا النظـام العـام الاقتصادى فى

قانون العقوبـات أنـه نظـام مصطنع ـ فـالجرائم الاقتصادية تعد جرائم صنـاعية ـ خلافـا للجرائم التقليدية كالقتل والسرقة والقذف . . . . بمعنى أن الجرائم الاقتصادية ليست أفعالا مستهجنة طبقا للثعور العام للأفراد ، مما يؤدى إلى عدم توافر الشعور باستياء الأفراد من مرتكبها ـ كما أن مقترفها لا يشعر أحيانا بتأثيم الإجرام ـ فنظره المجتمع إلى مرتكبى هذه الجرائم تختلف عن نظرتـه إلى مرتكبى جرائم القتل والضرب ـ فهذه الجرائم تفصح عن فساد أخـلاق مرتكبهـا لأنها انتهـاك لقواعد الأخلاق ـ أمسا الجرائم الاقتصادية ، فهى أفعال تتعـارض مـع قواعد القـانون الاقتصادى الذى يحمى مصالح اقتصادية معينة ، فارتكابها يتضمن عصيانـا لأوامر المشرع الذى يستهدف من ورائها تحقيق مصلحة المجتمع ـ لذا قيل بأن الجرائم الاقتصادية لا تتعارض مع القيم الأخلاقية السائدة فى المجتمع ، لأنها من خلق المشرع ومن صنعه ـ فالعقاب على هذه الجرائم لا يعتمد على أسس فلسفية ، أو أخلاقيـة أو اقتصادية ثابتة ـ كمـا هو الحسال فى جرائم 
السرقة والقتل ـ و إنمـا لـه طابع خاص يجرى وفق ظروف معينة ـ فمـا يعد فى نظر الثارع جرائم اقتصادية فى فترة زمنية معينة ، فإنه لا يعد كذلك بعد انقضاء تلكك الفترة

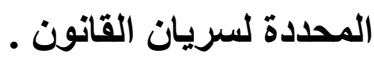

ومن ثم يظلب فى هذه الجرائم أن تكون جرائم وقتية يهدف المشرع من ورائها حمايـة أوضاع اقتصادية معينة (") ـ فضلا عن أن التظظيم الاقتصادى عادة مـا يكون

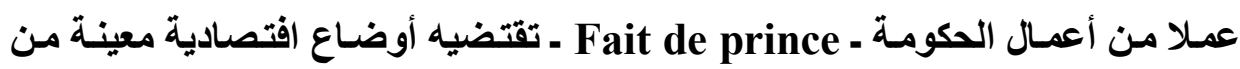

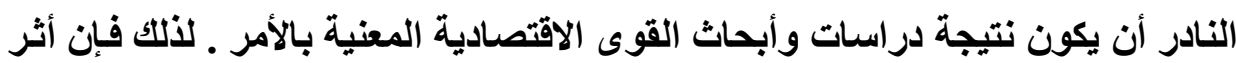

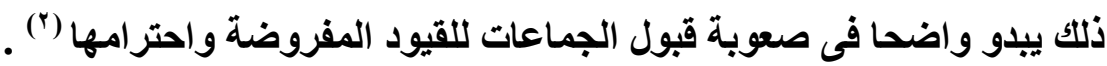
وعلى ذلك فبان القول بعدم تعارض الجرائم الاقتصادية مـع القيم الأخلاقيـة فى المجتمع استمد من كونها نتيجة للتــل التحكمى من قبل السلطة العامـة فى مجال

النشاط الاقتصادى ، ذلك التذخل الذى يقتضيه تغيير السياسة الاقتصادية للاولة (") . و الواقع من الأمر أن اللجوء إلى قانون العقوبات فى المجال الاقتصادى ، يمكن مع ذلك أن يحدث أثرا فى تعديل الصفة الصناعية للقانون الاقتصادى ، و وعدم منافاته التهات للقواعد الأخلاقية ـ ذلك أن تكرار الأزمات الاقتصادية من جانب ، والخصائص الجديدة

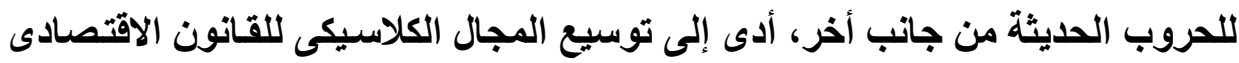

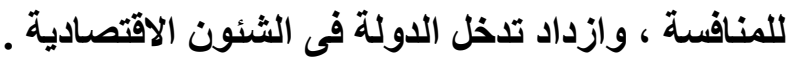

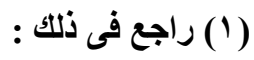
Mazard ( P. ) : Op. Cit., P. 24. ; Merle et Vitu : Op. Cit., No. 741, P. 595. 
وظهرت إلسى جانـب الأفكـار الكلاسـيكية لحريـة المنافسة ، والملكيـة وحريـة التجارة، أفكار جديدة أساسية ، تتأكد قيمتها يوما بعد يوم : أفكار اجتماعية تتعلق بحق

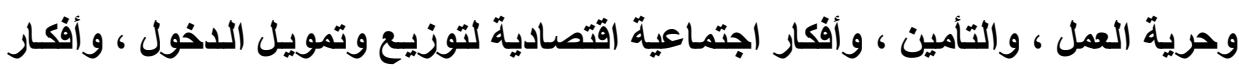
أخرى اقتصادية محضة لثبات الأسعار والنقود ـ ومن المسلم به ، حتى من وجهة نظر الرأسمالية الجديدة ، أن الدولة يجب أن تشجع أو تعزز السياسة الاقتصادية ـ بإعادة تنظيم البنيان الاقتصادى .

ولـم يسلم قـانون العقوبـات من التأثر بهذا التطور الحديث الموسـع للسياسة الاقتصادية ـ بـل ويوجد تشابه بين هذا التطور وتطور قانون العقوبـات ـ فكمـا يمتــ

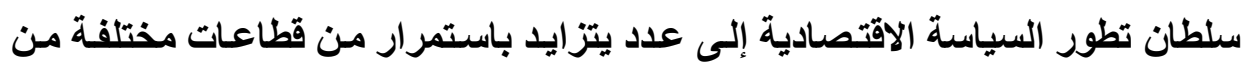
النشاط الإنسانى ـ فإن قانون العقوبات يتلخل نتيجة لذلك فى مواد كانت أجنبية عنه منذ عهد قريب ـ فلم يعد قاصرا على العقاب بشأن عدم الأمانة أو الاعتداء على حقوق الغير، بل أصبح يعاقب أيضا على الإخلال بالقواعد المستوحاه من الاهتمـام بالمصلحة

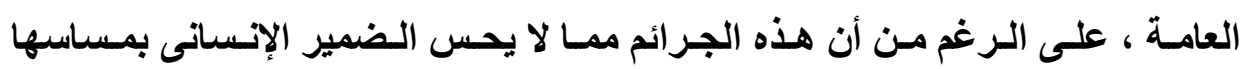

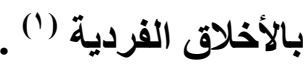

وعلى ذلك يتضح أن الوظيفة الحديثة لقانون العقوبـات فى الوقت الحاضر لـ تعد فقط ضـمانا لبقاء المجتمع ، و المحافظة على كيانـهـ ، بحمايـة مصالح قائمـة ، بل يسعى كذلك إلى العمل نحو تطور المجتمع ، بالعقاب على الأفعال التى تتضمن اعتداء على المصلحة العامة على الرغم من أنها قد لا تكون منافية للقيم الأخلاقية (؟).

Costa : Op. Cit., P. 93 ets. 
وبذلك يكون له دور فعال فى خلى قيم أخلاقية جديدة تتكون تدريجيا فى الشعور

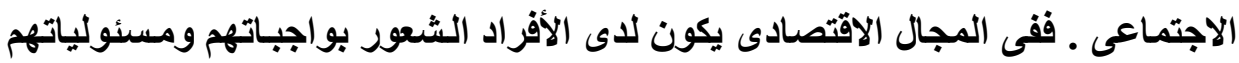

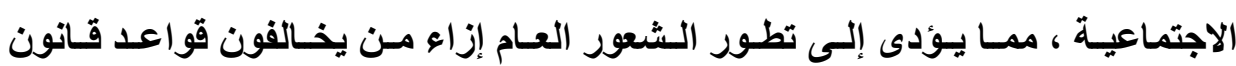

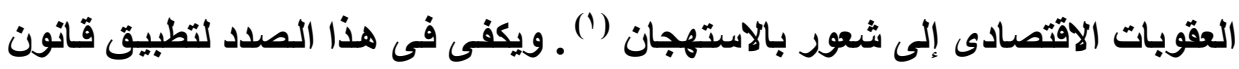

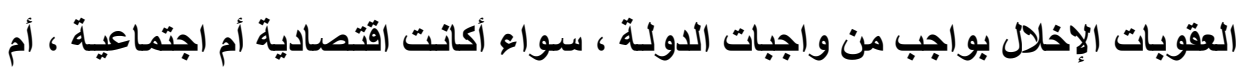
اقتصادية واجتماعية معا .

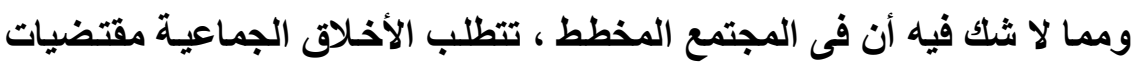

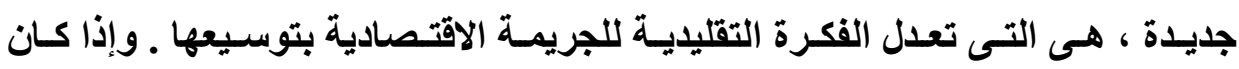

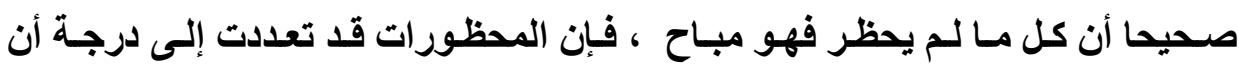

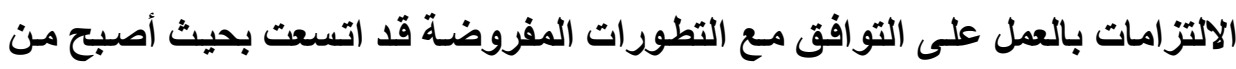

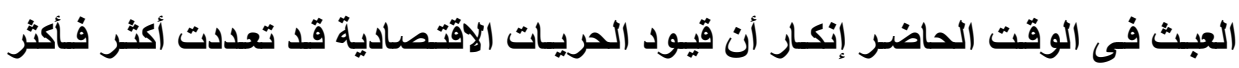

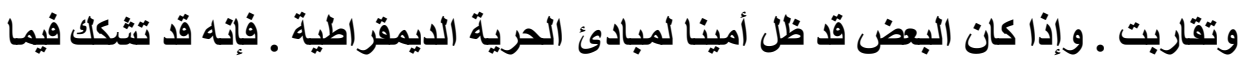

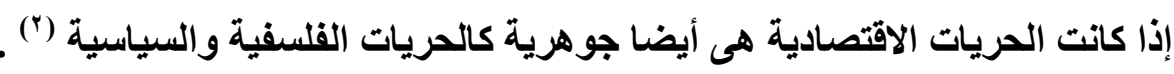
ويلاحظ أن القاضى الجنائى له دور كذلك فى خلق هذا الشعور العام، وهو مـا

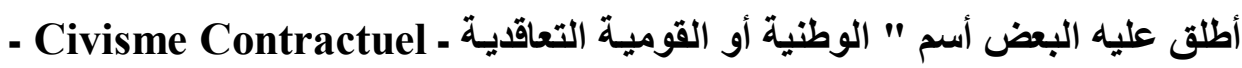

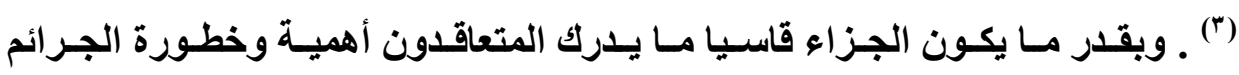

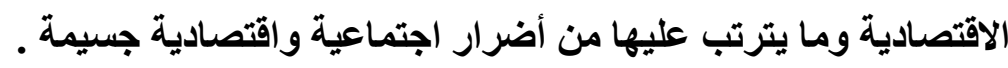

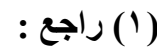

Carbonnier ( J. ) : - Droit Civil, Coll. Thémis, To 11, et v, 1979, P. u. f T. II, No. 115, P. 390.

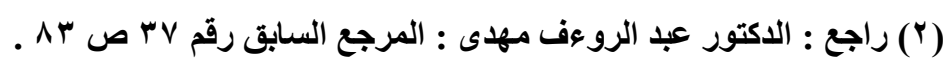

Costa ( J.L. ) : Op. Cit., P. 94.

Carbonnier ( J. ) : Op. Cit. T. II, No. 115, P. 390

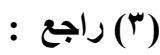

مجلتّ البحوث القانونيت والإقتصاديت 
وعلى ذلك فإن قانون العقوبات يعهد إلى النظام العام الاقتصادى بدور إيجابى ،

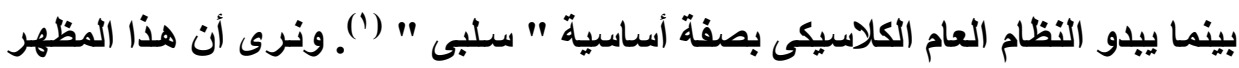

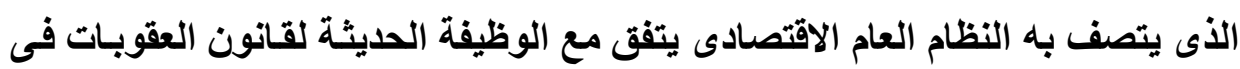

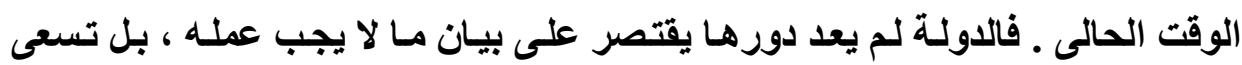

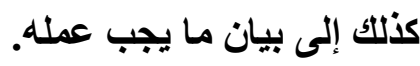

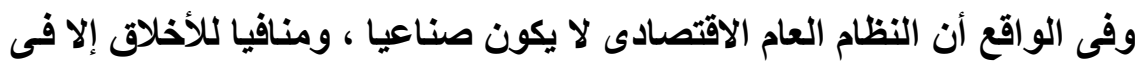

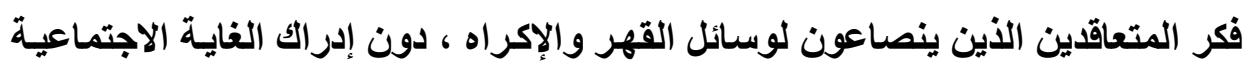
التى يستهدفها المشرع الاقتصادى .

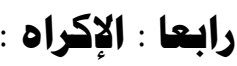

يتسم النظام العام الاقتصادى فى قانون العقوبات بصفة استثنائية ، بأنه بتضمن

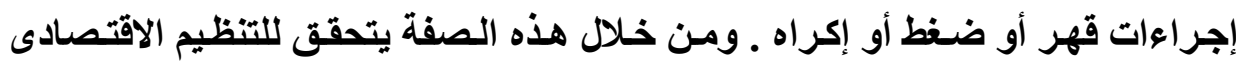
الفعالية ـ ذلكك أن التجربة فى هذا المجال الاقتصادى قد أسفرت عن طرق ووسيائل

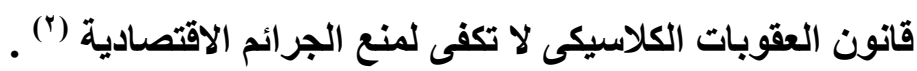
لذلك فبان المشرع يهتم بتحقيق وظيفة العقوبة فى الردع أو الزجر أكثر من اهتمامه بالإصلاح ـ وهذا يفسر التجاء المشرع إلى فرض عقوبات شديدة تؤتى أثرها

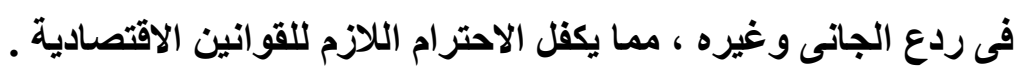

Pierr-Henri Bolle : La lutte contr la criminlité économiquen en Suisse, Rev. pén. suisse, No. 2, 1981, P. 140 ets. 
غير أن البعض يذهب فى هذا الصدد ، وبحق ـ إلى أن تشديد العقوبة لا يكفى لمكافحة الإجرام ، و إنما العبرة دائما بالسياسة الجنائية التى تتبع فى سبيل الكشف عن التهن الجرائم ومعاقبة مرتكبها ، فتثديد العقوبة مع سيادة الثُعور العام بأنه قلما تطبق على التى مرتكبى هذه الأفعال ، يتبعه بالضرورة التشجيع على ارتكاب تلكك الجرائم ، وبالتالى التي

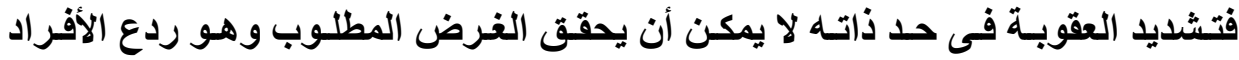
ودفعهم على احترام القو انين الاقتصادية (') ويلاحظ أن التشريع المـصرى لا يفرض عقوبـة الإعدام والعقوبـات السالبة

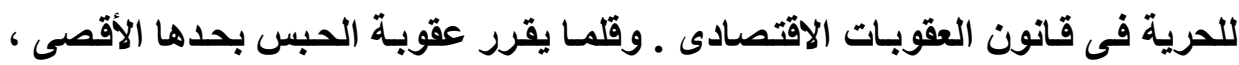
وعندما يفعل يجعل الحبس عقوبة اختيارية مع الغرامـة ـ غير أن العقوبات المالية هى أهم العقوبـات بالنسبة للجرائم الاقتصادية (†) . كمـا يظلب فى تلكت الجرائم أن تكون

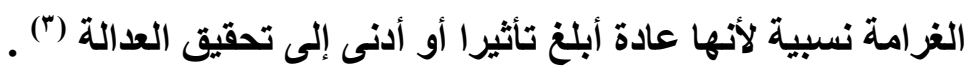
كما يفسح الصلح المجال أمام السلطة الإدارية من أن تحقق غرضها الحقيقى فى الردع ، إذ يلتزم المخالف بمحض إرادته بتنفيذ شروط الصلح بسبب سلوكه المخالف للقانون ـ وفى هذه الحالة يكون مقابل الصلح نوعا من الجزاءات الإدارية يحل محل

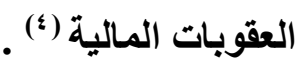

Levasseur ( G. ) : Cours Précité, P. 76.

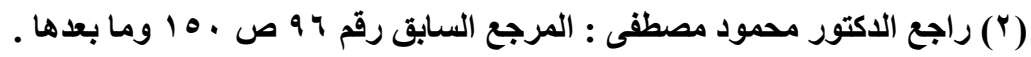

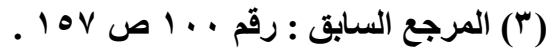

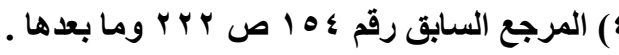


والواقع أن مـا يثار هنـا ليس شرعية اللجوء إلى إجراءات القهر فى مجـال التعاقد، بل إن الأمر يتعلق بفلسفة المشرع فى هذا الصدد ـ فقى الحقيقة ، لا يكفى

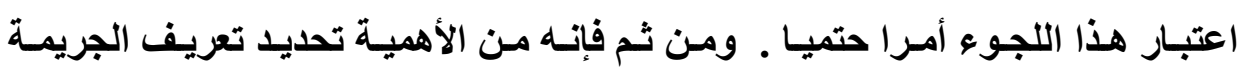

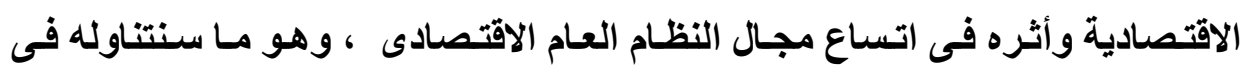

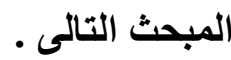




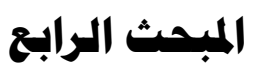 \\ تعريف الجريمة الاقتصادية \\ وأثره فى اتساع هجال النظام العام الاقتصادى الهم}

لا شكك فى اتساع مجـال النظـام العام الاقتصادى فى قـانون العقوبـات ، وهذا

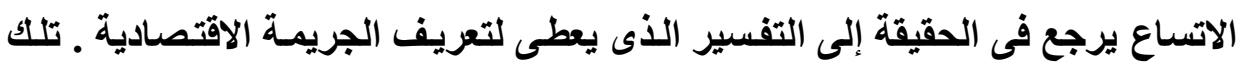

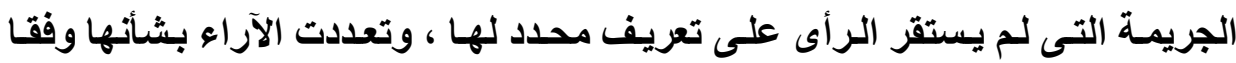

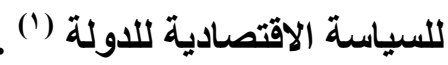

وعليه رأينا أن نعرض أولا لتعريف الجريمة الاقتصادية ثم نبين أثرها فى اتساع

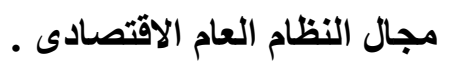

\section{أولا : تعريف الجريمة الاقتصادية}

تقدم القول بأن الرأى لم يستقر بعد على تعريف محدد للجريمة الاقتصادية ، وأن

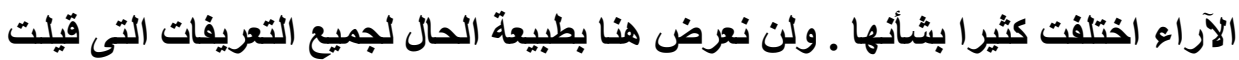

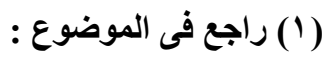

Léauté ( J. ) : les infractions économiques, Cinquiémes journées juridiques, Franco-yougoslaves, Paris, Nancy, Strasnourg, 23-28 mai 1960, publié in journés juridiques de la société de la législation comparé, ed. Cujas 1968, P. 109 ets. ; vivoda ( M. ) : Délits économiques en Droit pénal yougoslave, in journés précité. $P .83$ ets. 
فى هذا الصدد ، فهذا مـا لا يقتضيه المقـام ، ومـا يهمنـا هنـا فحسب أن نبين بعض

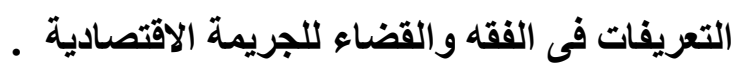

يذهب البعض إلى تعريف الجريمـة الاقتصادية بأنها " كل عمل أو امتنـاع يقع بالمخالفة للقواعد المقررة لتنظيم أو حماية السياسة الاقتصادية إذا نص على تجريمـه فى قانون العقوبات أو فى القوانين الخاصة " ( ) .

وقال البعض الآخر : إن الجريمة الاقتصادية " هى كل فعل أو امتنـاع من شـأنه

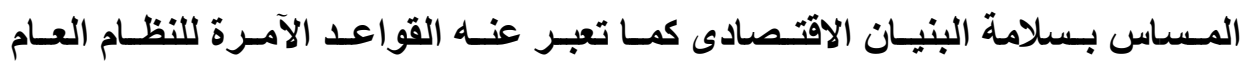
الاقتصادى المشمولة بـالجزاء الجنائى " () ـ والجريمـة الاقتصادية للى بعض الآخر هى " مباشـرة نشاط معين ، وسـواء تمثل فى تصرف اقتصادى أو سـلوك مسادى ،

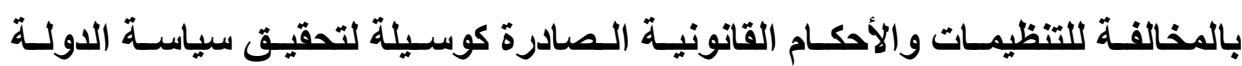

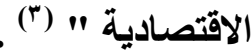

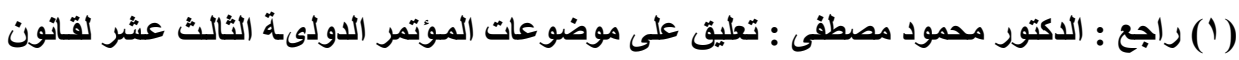

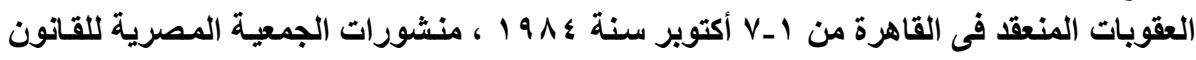

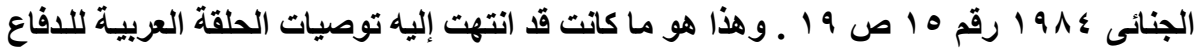

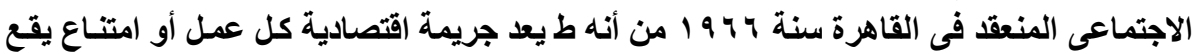

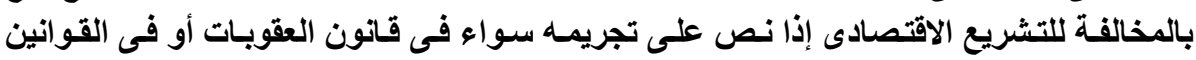

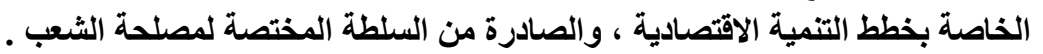

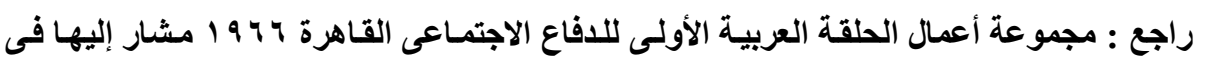

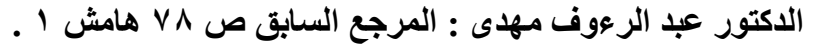

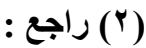

Vivosa ( M. ) : Rapport précité, No. 1. ets., P. 83 ets. 
والواقع من الأمر أن متطلبات الأخلاق أدت إلى تطور فكرة الجريمة الاقتصادية

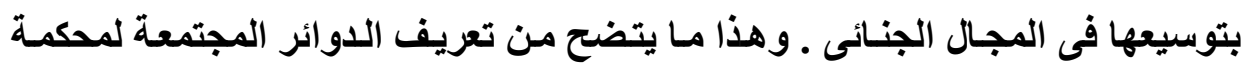

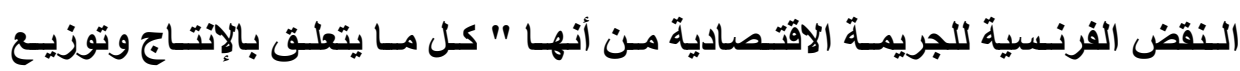
واستهلاك وتداول السلع والخدمات ، وكذلك مـا يتعلق بوسائل الصرف ، ويلخل فيها

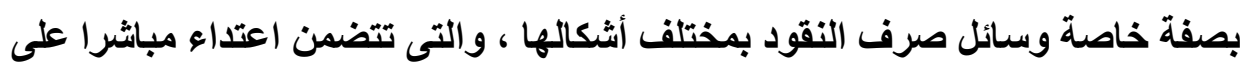
اقتصاد الدولة ، حيث تضطع الدولة بالتوجيه والرقابة مراعاة للظروف " (') .

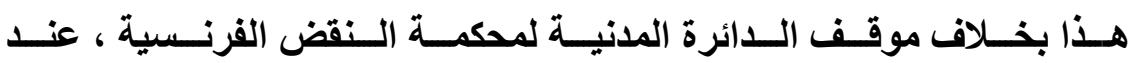
تعريفها للنظـام العـام الاقتصادى ، فالاتجـاه يبدو نحو الحد مـن آتـاره بقصد حمايـة الحريـة التعاقدية (") ـومن ثم فيان متطلبـات الجزاء أعطت تعبيرا واسعا للأخلاقيـات الاقتصادية، بينما المتطلبـات التعاقدية ، خلافـا لذلكت ، كفلت للنظام العـام الاقتصادى مفهومـا ضيقا ـ وبالتالى فإنه من المككن أن ينشأ نزاع بين احترام الإرادة التعاقدية

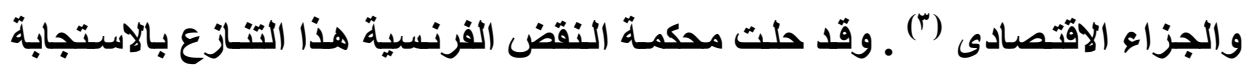

Cass. Ch. Réunies, 1 er. août 1949, J.C.P. 1949, 5033, Note leroy.

Malaurie ( ph. ) : Op. Cit., No. 82, P. 59.

Ibid : loc. Cit.

Crim. 15 juil. 1948, J.C.P. , 48, 4488; Malaurie; Op. Cit., No. 334 et 374. 
و هكذا فإن الفكرة الأخلاقية التى يضعها القضاة للنظام العام تارة مقيدة ، وتارة

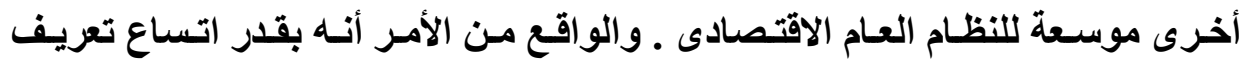

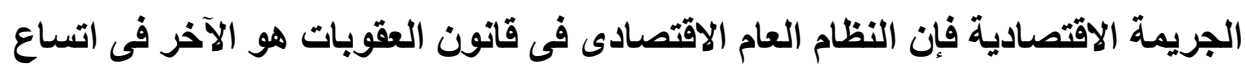

\section{ثانيا : هظاهر الاتساع الجنائى فى نطاق النظام العام الاقتصادى :}

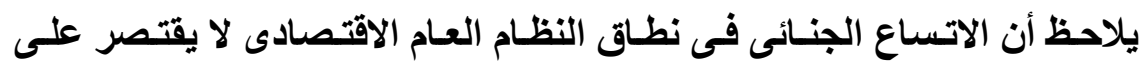

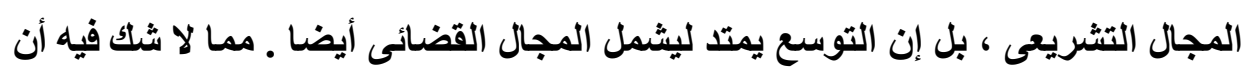

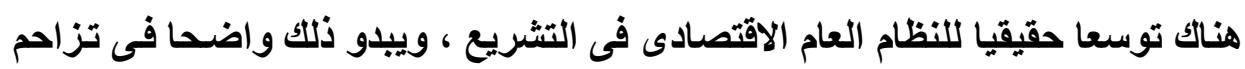

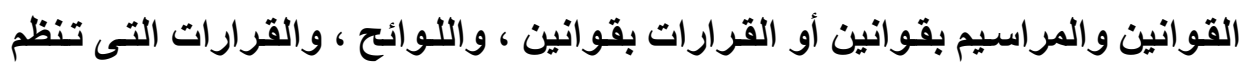

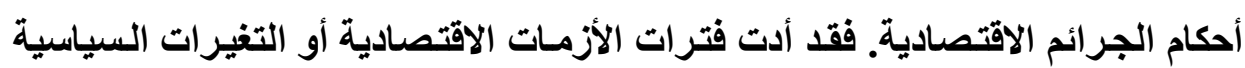
إلى ظهور نصوص جديدة متداخلة ، قد تبدو متعارضة مـع النصوص السابقة عليها التى لم تلغ صراحة (')

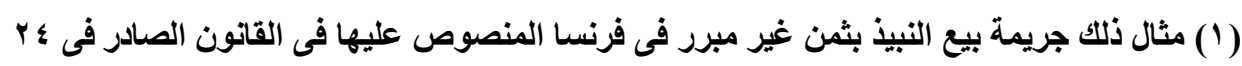

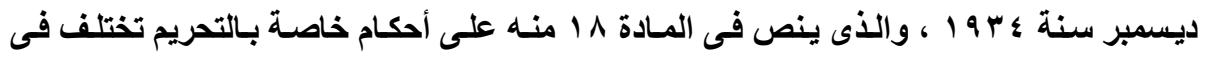

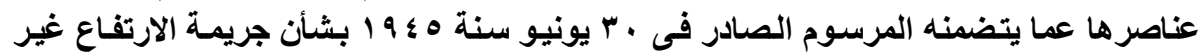

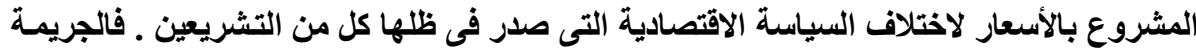

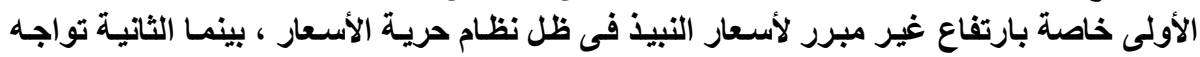

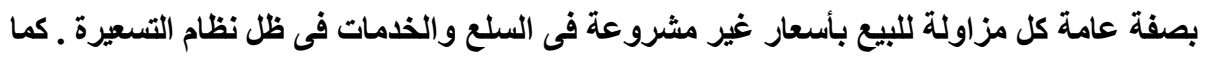

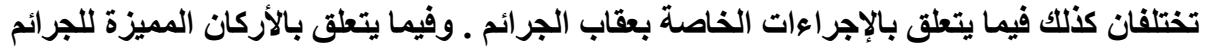

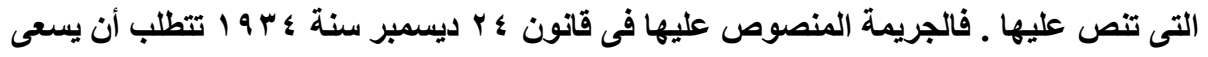

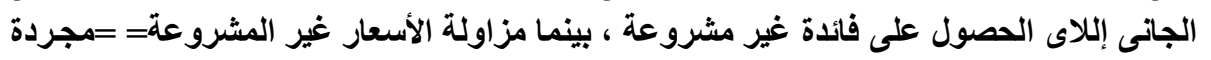

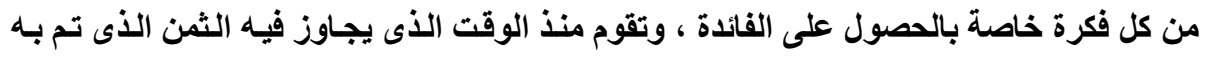
البيع السعر المحد ـ راجع فى هذه التفرقة : $=$ 
لذلك يحرص المشرع منعا للاضطراب عند تعديل أحد القوانين الاقتصادية أو

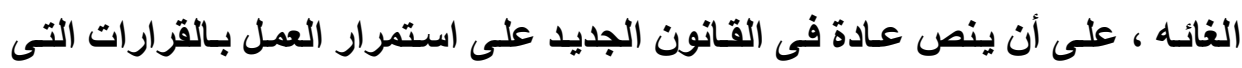

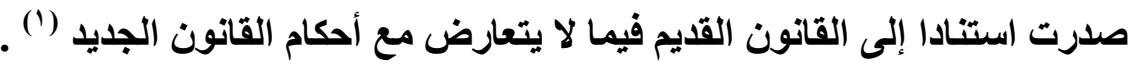
ويلاحظ أن عدم الدقة فى صياغة نصوص الجرائم الاقتصادية ، تقتضى أن يكون للقضاء سلطة واسعة فى تفسيرها ، ولذلك فِإن التفسير القضائى يعد مصدرا قضائيا للنظام العام الاقتصادى ، ومن ثم فإنهه بالرغم من أن النظام العام فى قانون العقوبات يجد مصدره الوحيد فى التشريع ، فإن توسع النظام العام الاقتصادى اتجه إلى الى التى أن يصبح ظاهرة قضائية ، أو بمغنى أصح ، مظهرا للسياسة الجنائية . ويبدو ذلك فى توسع محكمة النقض عند تفسير ها لنصوص الجرائم الاقتصادية،

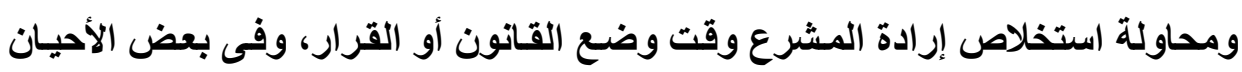

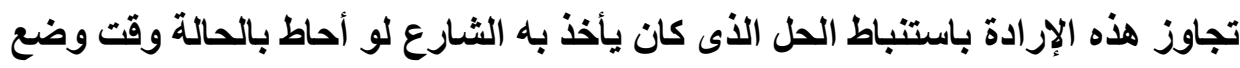

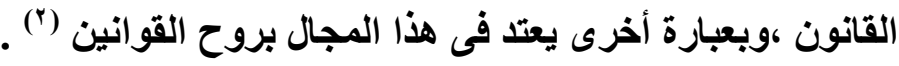
كمـا شـهـ القرن العشرون تطورات على جاتب كبير من الأهمية فـى قـانون العقوبات الاقتصادى ، ميزت تدخله فى الحياة الاقتصادية ، فبعد أن كان النظام السائد

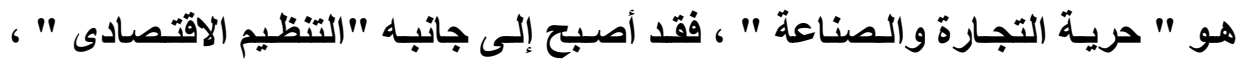

Merle et Vitu : Op. Cit., No. 920, P. 730; Crim. 19 oct. 1965, Gaz. Pal. 1966, 2, 308; Crim. 16 fév. 1966 et Angérs 24 mars 1966 ( 2 décisions ), Gaz. Pal. 1966, 1, 337.

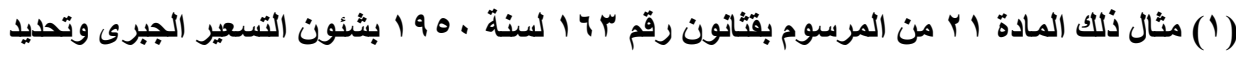

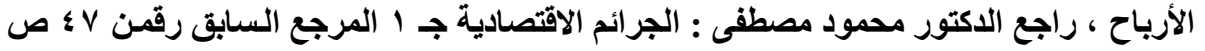


وأخذت القوانين تتزايد (') ـ واتجهت التشريعات ، على اختلاف أنظمتها السياسية إلى تشديد العقوبة فى الاعتداعات التى تقع على النظام العام الاقتصادى () . غير أنه من ناحية أخرى يلاحظ أن السلطات الإداريـة تساهم بنصيب كبير فى وضع أحكام القانون الاقتصادية ، وتقوم بمفردهـا بمراقبة تطبيقه ، بـل ولهـا رأى فيمـا إذا كانت المصلحة العامة تقتضى رفع اللدعوى على من يخالف هذه الأحكام بارتكـاب جريمة اقتصادية . وقد يكون من شـأن الإدارة ، أحيانـا ، حفظ الأوراق ، الأمر الذى يسلب جهات القضاء الجنـائى المختصة سلطاتها فى هذا الصدد (") ـ ومهمـا يكن من أمر الاتساع الجنـائى لمجـال النظـام العـام الاقتصادى ، فِإن هذا الاتسـاع يختلف بـاختلاف النظـام

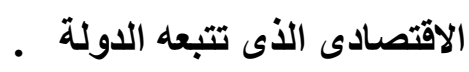

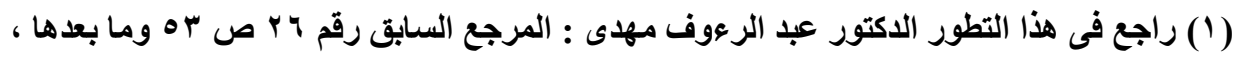
Costa ( J. l. ) : Rapport précité, in Mélanges patin, P. 92 ets.

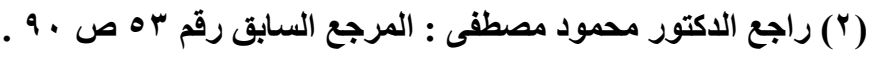

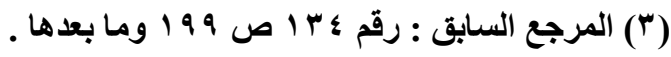

$$
\begin{aligned}
& \text { مجلتً البحوث القانونيتة والإقتصاديت }
\end{aligned}
$$




\section{الفصل الثانى}

\section{الخروج عن الأحكام العاهة فى القانون الجنائى}

سـبق أن ذكرنـا أن تـأثير التطورات الاقتصادية لـم يقتصر على الخروج عن المبادئ الأسناسية فى القانون العقوبـات ، بل وقواعد الإجراعات الجنائية كذلك ، فقد شـمل المبـادئ الأسـاسية فى التجريم والمسئولية الجنائيـة ، كمـا امتـــ إلى إجراءات

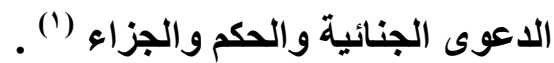
وسـنتـاول هـذه التحـولات التـى ظهرت فـى المبـادئ الأساسـية فـى القـانون

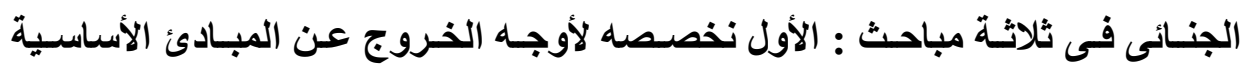
فـى قـانون العقوبـات ، والثـانى لأوجـه الخـروج عـن أحكـام الإجـراعات الجنائيـة ، وفى المبحث الثالـث نبـين اتجاهـات الـسياسة الجنائيـة فـى مجـال النظــام العـام

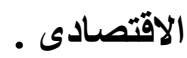

$$
\text { : (') }
$$

Léauté ( J. ) : Rapport Précité, P. 110 ets.; Delmas Marty ( Mireille ) :Rendre le droit Pénal des affaires Plus dissuasif, Rev. Dr. Pén. Et de Crim. 1981, P. 301, Merle et Vitu : OP. Cit., No. 744, P. 596. 


\section{المبحث الأول}

\section{الخروج عن المبادئ الأساسية}

\section{فى قانون العقوبات}

يميـز قـانون العقوبــات التقليـــى ، فـى النظريــة العامــة للجريمــة ، بـين

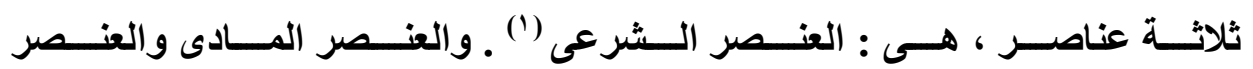

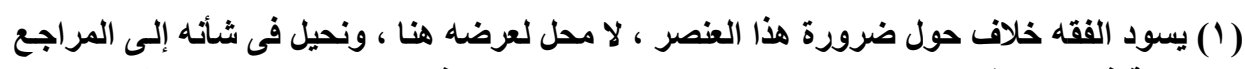

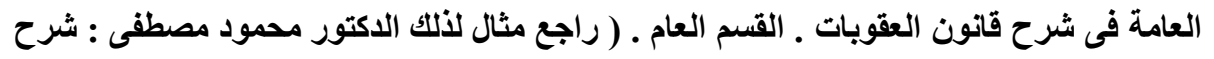

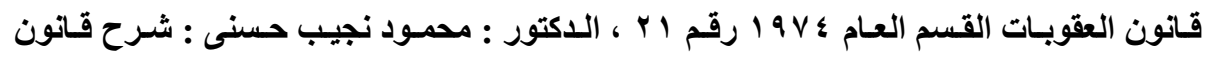

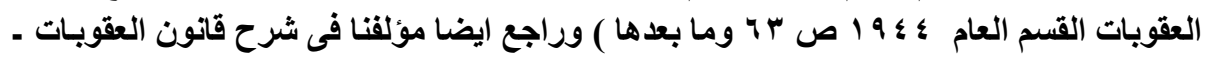

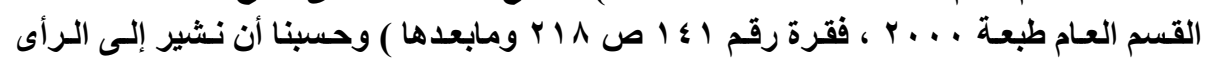

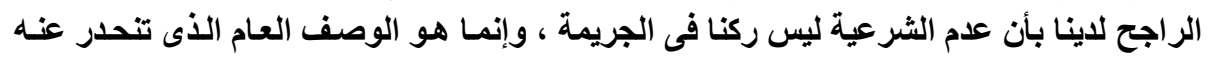

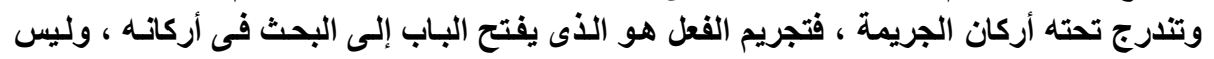

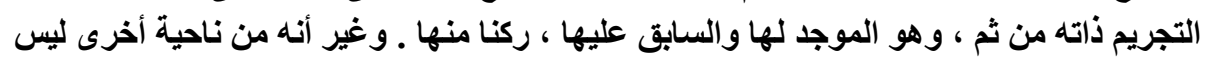

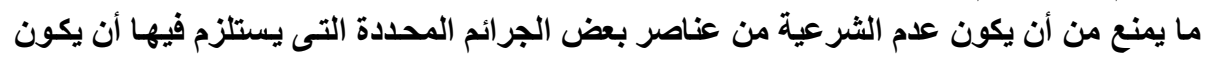

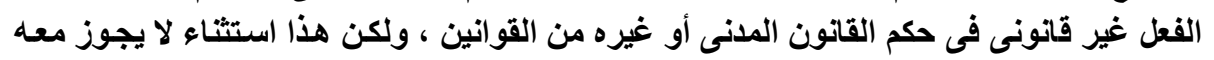

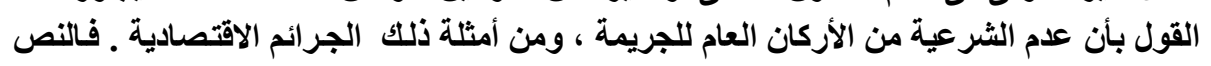

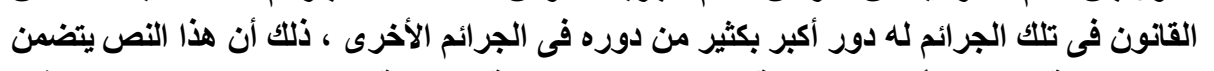

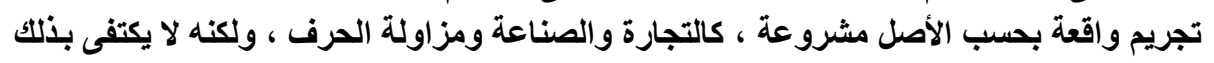

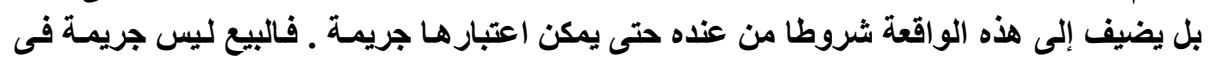

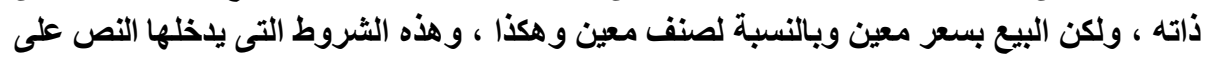

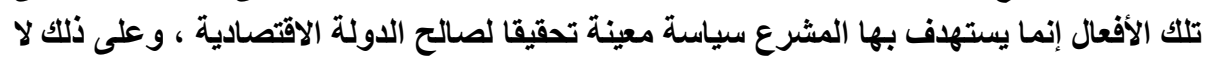

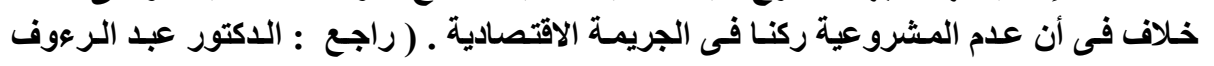

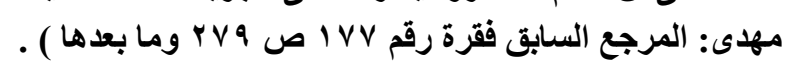

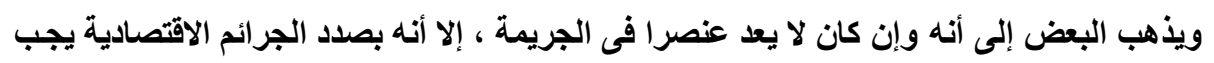

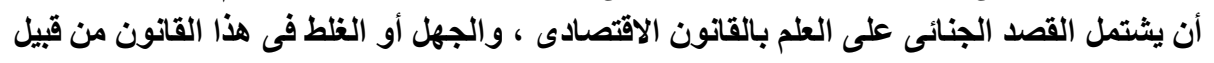
$=$ 
المعنوى (') . وقد خضعت هذه العناصر الثُلاثة تحت تأثير النظام العام الاقتصادى ، لتحولات عميقة (r) . وسنتتاول كل عنصر منها فى مطلب مستقل .

\section{المطلب الأول \\ الخروج عن الأهكام العامة للركن الشرعى}

يبدو الخروج عن الأحكام العامـة للركن الشرعى من نـواح متعددة ، أولا : من

حيث وظيفة قاعدة شرعية الجرائم والعقوبات ، وثانيا : من حيث مصادر النظام العام

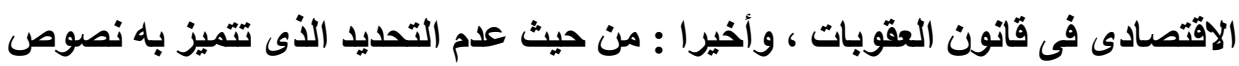

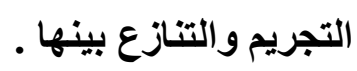

أولا : وظيفة قاعدة شرعية الجرائم والعقوبات :

من المبادئ الأساسية فى قانون العقوبـات أن التجريم الجنـائى لواقعة مخالفة

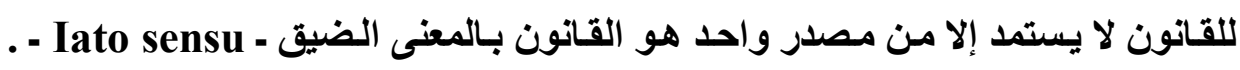

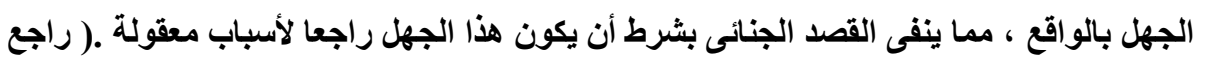

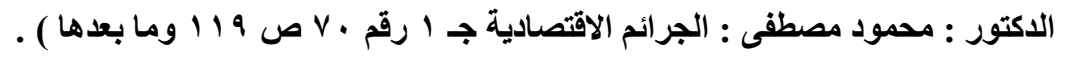

: (1)

Bouzat( P. ) : Traité, T. 1, No. 75 ets.; Merle et Vitu : Traité T. 1, No. 338, P. 444 ets.

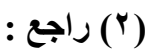

Delmes Marty ( M. ) : OP. Cit., P. 301; léauté : Rapport Précité P. 110 ets. 


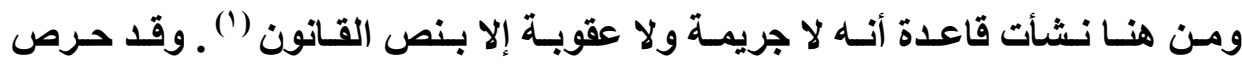
المشرع الجنائى على النص عليها فى قانون العقوبـات ، ( المـادة الخامسة من قانون العقوبـات المصرى ، ويقابلهـا المـادة الرابعـة مـن قـانون العقوبـات الفرنسى القديم ،

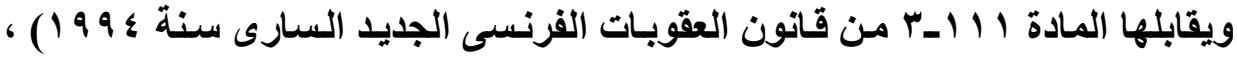
باعتبارهـا أهـم ضـمان للحريـات الفرديـة إزاء تحكم السلطتين التنفيذيـة والقضائية ، وبالتالى اعتبر هذا المبدأ أساسا جوهريا فى النظام الجنائى (؟) .

غير أنـه لمـا كـان النظام العـام الاقتصادى فى قـانون العقوبـات يضطلع بصفة أسساسية بوظيفة حماية المجتمع على حساب وظيفة حماية الحريات الفرديـة ، لذلك فيان القاعدة لا مساس بها من حيث المبدأ ، غير أن الوظيفة التى تقوم بها قد تغيرت (") ـ إلا أنه لا يمكن القول ، بالرغم من ذلك ، بالتخلى عن القاعدة تمامـا ـ ذلك أن دقة تفاصيل النظام العام التوجيهى ، تقتضى الأخذ بالقاعدة إذ أن وجود النص التشريعى ضرورى فـى قـانون العقوبـات الاقتـــادى لبيـان الأفعـال والامتنـاعـات المخلـة بالنظــام العـام

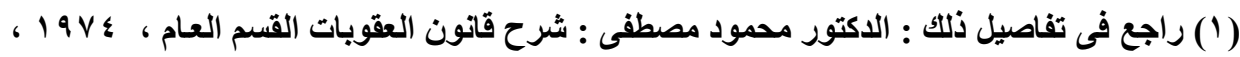

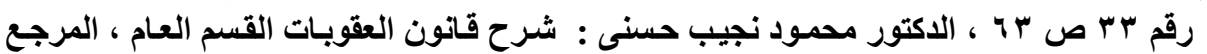

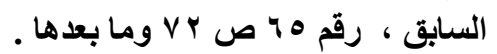

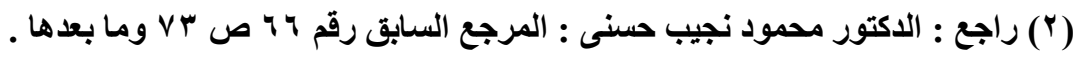
Bouzat : Op. Cit., No. 77 ets.; Merle et Vitu : Op. Cit., No. 146 ets., P. 219 ets. (זّ) راجع فى ذلك :

Leaute ( $J$. ) : le changement de fonction de régle " nullum crimen sine lege “, Etude Hmel, Dalloz, 1961, P. 81 ets. 
و العقوبات المقررة لها ، ليس فحسب من أجل المعاقبة على ارتكابها ، بل أيضا توقى

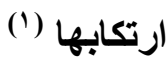

غير أنـهـ وإن اتفق مبدأ لا جريمـة ولا عقوبـة إلا بنص فـى قـانون العقوبـات الاقتصادى ، مع المبدأ فى قانون العقوبات بصفة عامة ، من حيث وجوب توافر النص التص

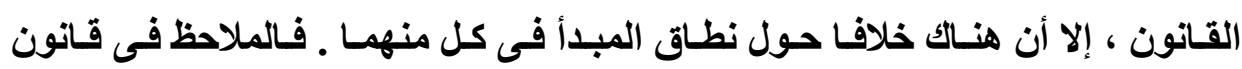
العقوبات الاقتصادى ، أن أغلب الدول لم تلتزم مقتضيات القاعدة ، فليس القانون

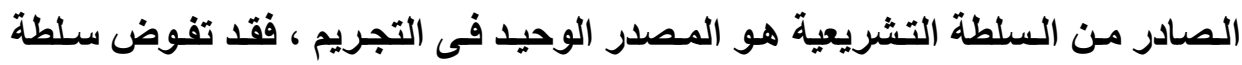

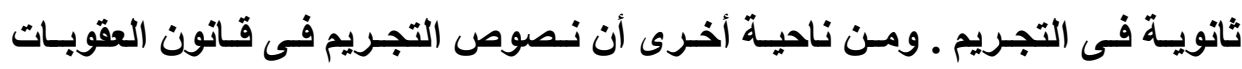

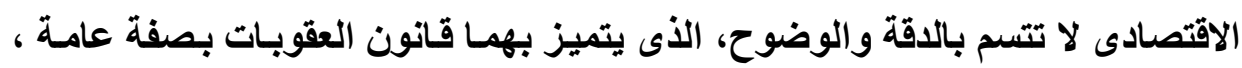

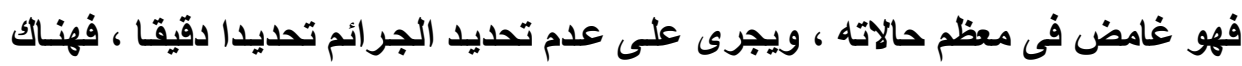

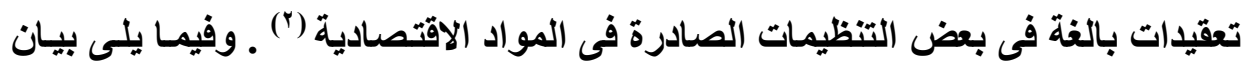

ثانيا : هصادر النظام العام الاقتصادى فى قانون العقوبات:

يهلف مبدأ شرعية الجرائم والعقوبات فى المفهوم التقليدى إلى ضمان حماية الحرية الثخصية إزاء خطر التعف من جاتب السلطة التنفيذية ـ لذلك فِان الأصل فى التى

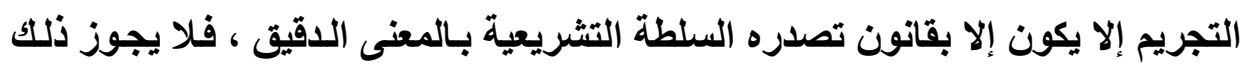

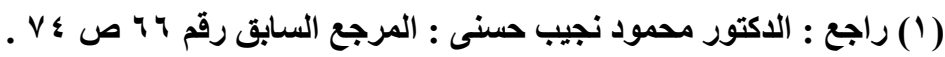

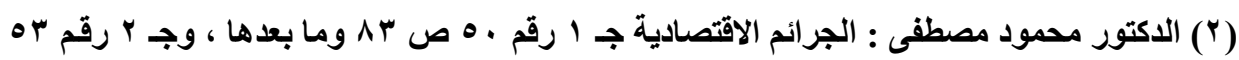

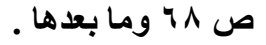


للسلطة التنفيذية ـ وهذه القاعدة يمليها مبدأ الفصل بين السلطات ، إذ لا يجوز للسلطة التنفيذية أن تتدخل فى أعمال السلطة التثريعية ، إلا فى نطاق محدود (') . إلا أنه نظر الأن الدولة أصبحت هى المسبطرة على الاقتصاد ، فى ظل نظام الاقتصاد الموجه ، فقد اتجه المشرع إلى الخروج عن هذا المبدأ لمواجهة الضرورات الاقتصادية التى تستلزم تدخلا سريعا من جانب السلطات العامـة ـ فتخلى المشرع عن التجريم بقانون ، ولجأ إلى ذلك عن طريق اللائحة أو القرار الوزارى ـ ذلك أن التشريع فى هذا المجال يتطلب دراية فنية قد لا تتوافر لدى الدش المشرع . ومن ناحية أخرى ، كثيرا ما يطرأ على الجرائم الاقتصادية تعديل أو إلغاء ، ذلك أن النظام العام الاقتصادى لقانون العقوبات يتميز بعدم الثبات ، فهو متحرك بطبيعته ، ومن خصائصه المرونـة ، إذ تتطور الظروف الاقتصادية بسرعة وبغير انقطاع ، ممـا يقتضى مزيدا من تفويض السلطة التنفيذية فى مجال احترام النظام العام الاقتصادى ،

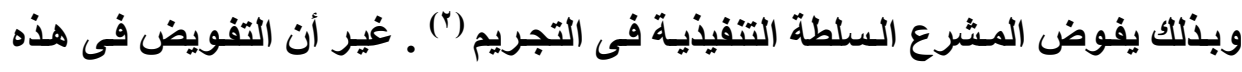
الحالة ليس تفويضا كـاملا ، إذ أن المشرع يخطط المبـادئ العامـة فى التجريم ويحدد العقوبة ، أما السلطة المفوضة فتحدد عناصر الجريمة (") .

(1) راجع فى ذلك ، الدكتور محمود مصطفى : المرجع السابق جـ ا رقم 0؛ ص Y V وما بعدها .

Merle et Vitu : Op. Cit., No. 156, P. 233 ets.

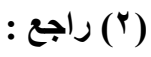

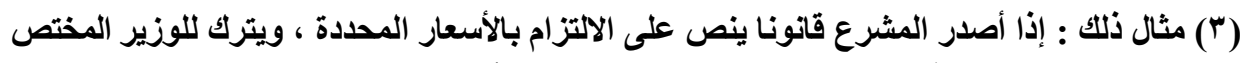

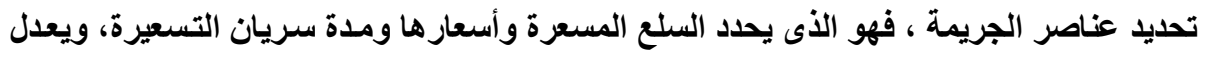

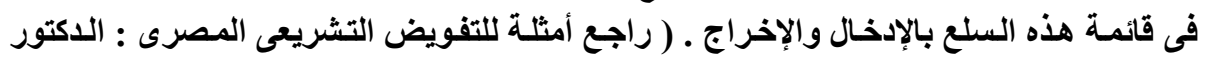

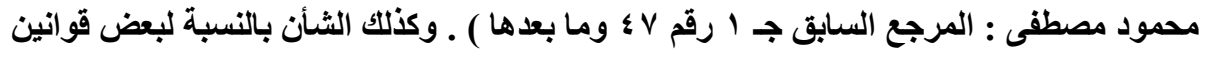

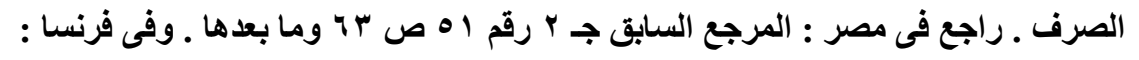
Encycl. Dalloz, Droit criminel, Vo. Change, No. 23. 
وقد ثار البحث حول شرعية التفويض التشريعى ، إلا أن جمهور الفقهاء ، قد أيـده فى تجريم الخروج على القوانين الاقتصادية ، باعتباره ضـرورة يلتجئ إليها

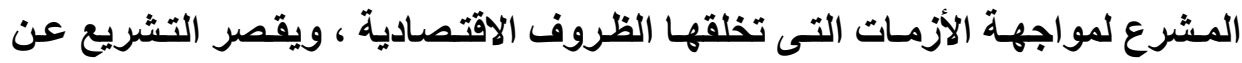

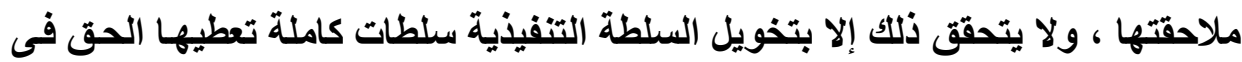

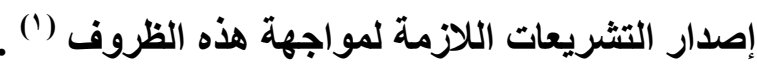
لذلك فإنه من الطبيعى أن أغلب النصوص الخاصة بالنظام العام الاقتصادى فى

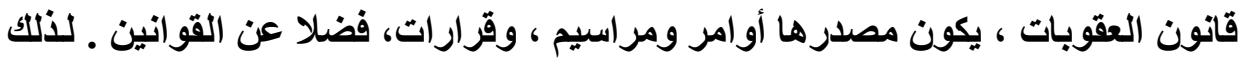
فإن دور السلطة التنفيذية يصبح دورا راجحا فى إعداد القاعدة القانونية (†) . والواقع من الأمر أن التفويض التشريعى لا يحقق غرضها إلا إذا عهد بـه إلى التى

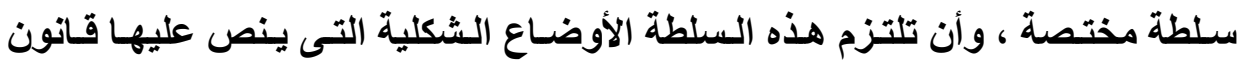
التفويض ، وأن يجئ قرارهـا فى نطاق الإطار الذى حدده لها المشرع ـ ويعتبر ذلك التك أعمالا لقاعدة شرعية الجرائم والعقوبات ، إذ ينبغى أن تتقيد السلطة التتفيذية المفوضة التئة

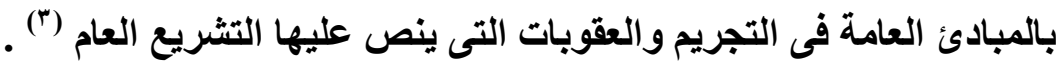

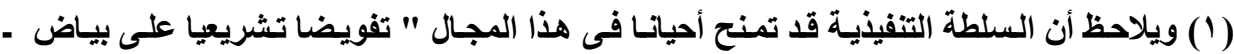

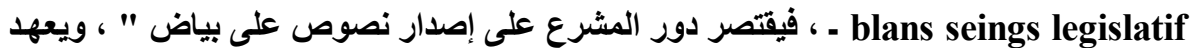
إلى السلطة المفوضة بملئها ، راجع فى نلك :

Merle et Vitu : Traité cit. No. 157, P. 234. ; Dr, pen. Sp., No. 745, P. 596 ets.

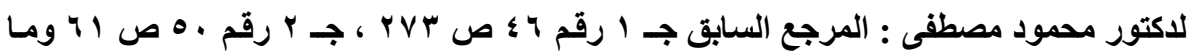

Bosly et spreutels : Op. Cit., No. 28, P. 42 ets.

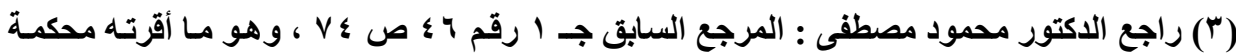

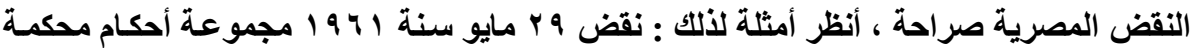
$=$ 


\section{ثالثا : عدم تحديد نصوص التجريم والتنازع بينها}

مسن الأمسور الملحوظـة فـى التشريعات الاقتـصادية بـصفة عامـة أن نـصوص التجريم لا تتسم بالاقة والوضـوح التى يتميز بهـا قـانون العقوبـات ، بـل قـ يشوبها

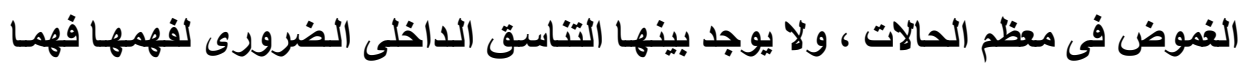

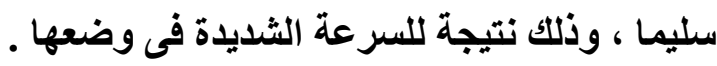
ويرجع ذلك إلى أن الأنواع المختلفة من الوقائع الاقتصادية لا تفهم فى أشكال

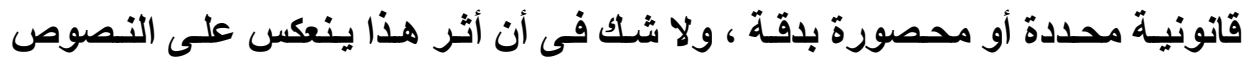

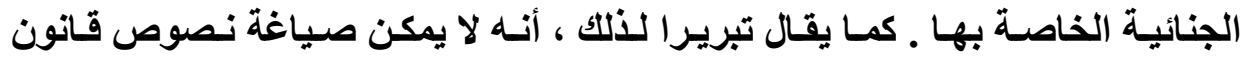
العقوبـات الاقتصادى بنفس الدقة التى تصاغ بهـا نصوص قانون العقوبـات العادى ، بالنظر إلى اختلاف موضوع كل منهما ـ فالقانون الاقتصادى يتميز بالمرونة والحركة ، ويتطلب استعمال تعريفات عامة ، بحيث تواجه الاحتمالات المعتادة للسياسة الاقتصادية ، وليس فى ذلك خروج على قاعدة الشرعية ، وكل ما هنالك أن المشرع يخول القاضى سلطة واسعة فى تطبيق النصوص وتفسير ها على ضوء الغرض من التشريع (') . وقد كان من نتيجة تعقد مصادر النظام العام الاقتصادى فى قانون العقوبـات ، أن تعددت النصوص التى تبدو واجبة التطبيق على ذات الواقعة(؟) ـ الأمر الذى ينشأ عنها تنازع فى الأوصاف الإجرامية - Conflits de qualification ـ ، ولا يثار مثل هذا التنازع فى قانون العقوبات التقليدى إلا نادرا ، وذلك نظرا إلى التحديد الذى تتميز بـه

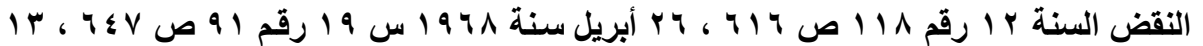

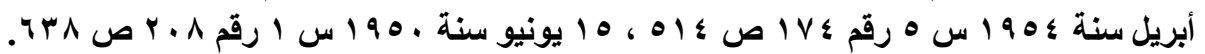

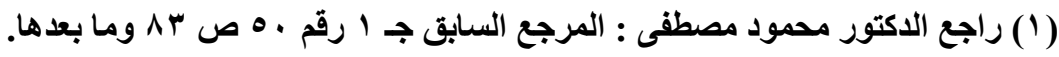

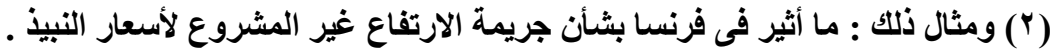


نصوص التجريم ، و إلى أن التجريم الجنائى لواقعة مـا ، يعد بـالرغم من ذلك إجراء

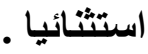

وإذا كان التفويض التشريعى فى تجريم الخروج عن القوانين الاقتصادية يجد

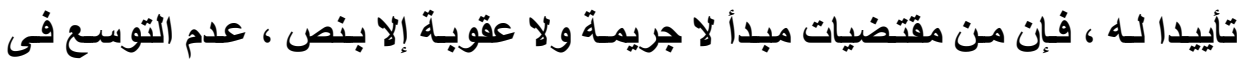

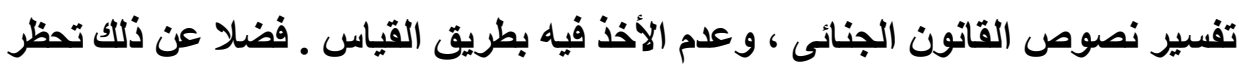

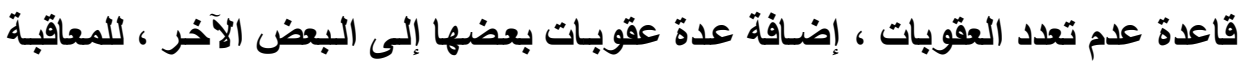

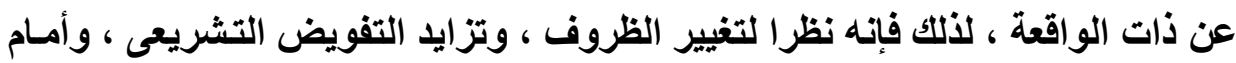

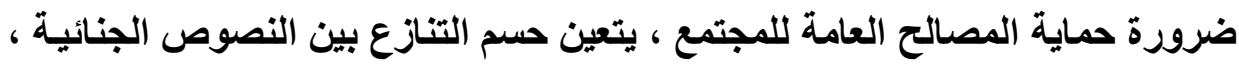

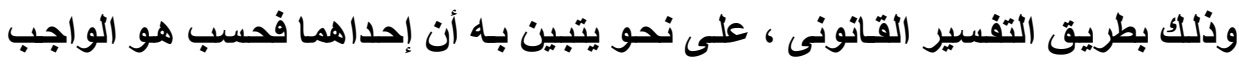

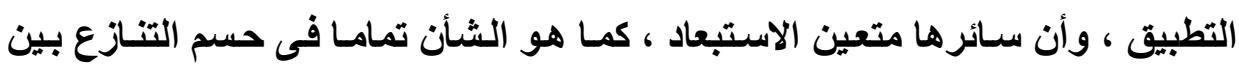

$$
\text { نصوص القانون العام (') ل }
$$

وعلى ذلك يتضح أن الوظيفة الجديدة لقاعدة شرعية الجريمـة ، بعد ازديـاد

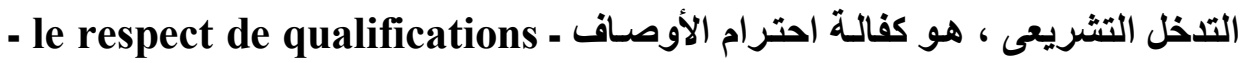

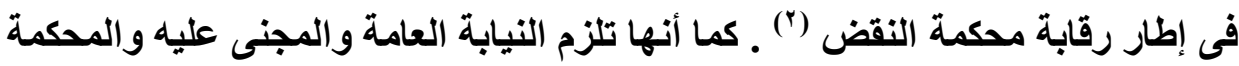

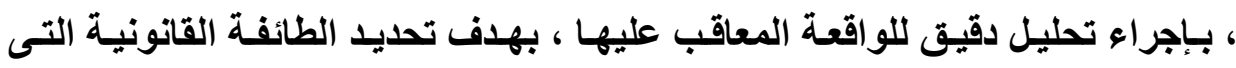
تندرج تحتها ، ثم اختيار النص الواجب التطبيق ، وهذا هو الهاف من عملية التكييف ،

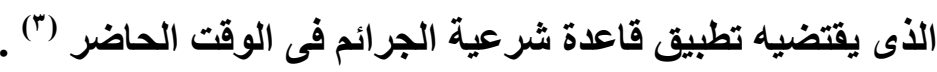

(1) راجع فى الموضوع : الاكتور محمود نجيب حسنى : المرجع السابق رقم ه ... ص ع ع ومـا

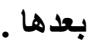

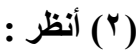
léauté ( J. ) : art. Preéité, P. 85.

Merle et Vitu : Dr. pén. Sp., v. I, Op. Cit., No. 14, P. 20. 


\section{المطلب الثانى \\ الخروج عن أحكام الركن المادى المى}

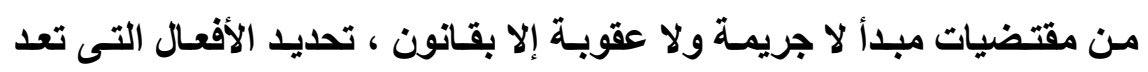

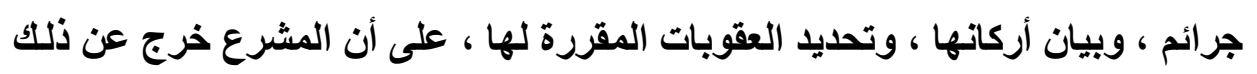

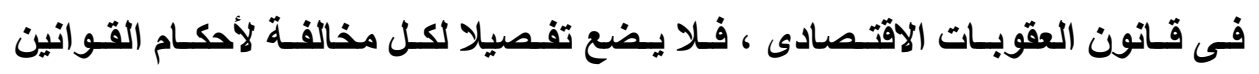

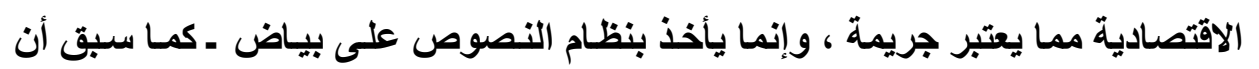

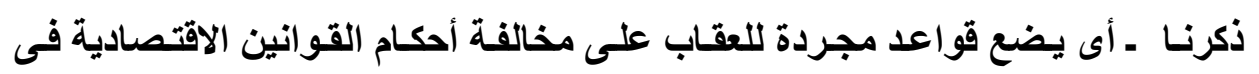

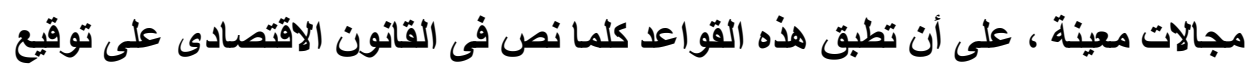

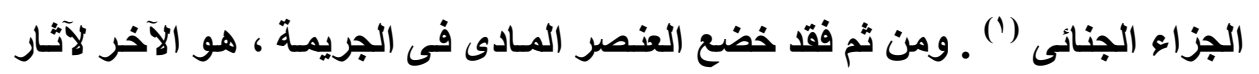

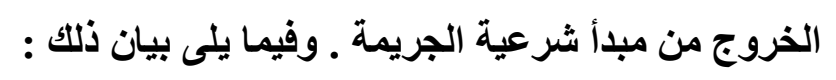

عدم وضوح العنصر المادى :

نظرا لكثرة القو انين الاقتصادية ، واتساع قائمسة الوقائع المعاقب عليها بدرجة

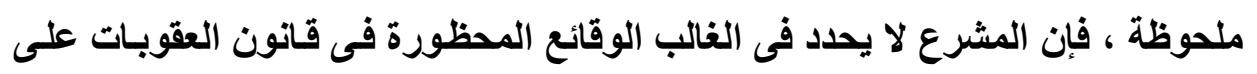

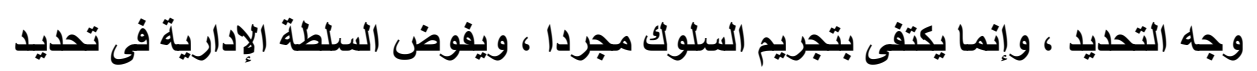
العنصر المادى للجريمة ، باعتبارها السلطة التى تضطلع بحماية النظام العام (") .

(1) راجع : الاكتور محمود مصطفى : المرجع السابق جـ 1 رقم 0r ص مه ـ.

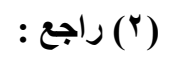

Delmas - Marty ( M. ) : Rendre la droit Pénal des affaires Plus dissuasif, Rev. Dr. Pén. Et de crim. 1981. , P. 30.

ه مجلتّ البحوث القانونيت والإقتصاديت 
ومن قبيل ذلك بصفة أساسية ، مجال الرقابة على عمليات النقد ، فقد جرت

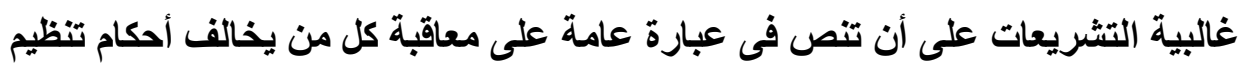

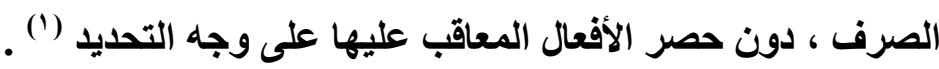
إن عدم تحديد العنصر المـادى للجريمـة أمر يقتضيه عدم ثبـات النظـام العـام

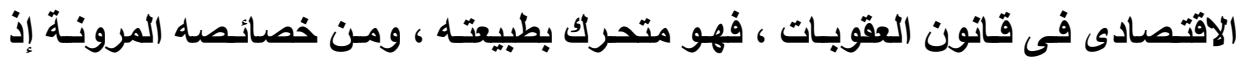
تتظور الظروف الاقتصادية بسرعة وبغير انقطاع (") ـ غير أن مثل هذا السلوك يمكن

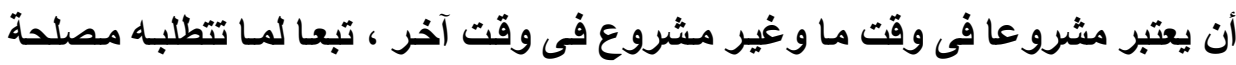

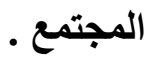

والواقع أن مثل هذه الطريقة تعد خروجـا خطيرا على مبدأ المسساواة أمسام القانون، وذلك فى الحدود التى يؤدى فيها عدم تحليد العنصر المسادى إلى اعتبار أثخاص كمتهمين رغم أن إجرامهم عرضى محض ويرجع إلى الظروف .

\section{المطلب الثالث}

\section{الخروج عن أحكام الركن المعنوى}

من أهم صور الخروج عن المبادئ الأساسية فى قانون العقوبـات ، هو الذى الذى

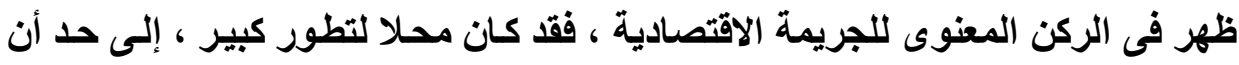

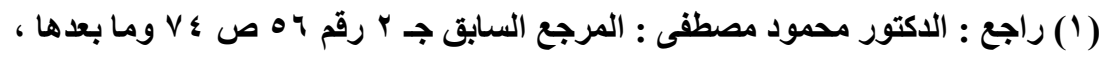
Costa : art. Précité, P. 118.; Encyl. Dalloz, Droit criminel, Vo. Change No. 23.

(ץ) راجع فى هذا المغنى : الدكتور محمود مصطفى : المرجع السابق جـ ا رقم هب ص VO ومـا 
البعض رأى فيه تشويها لفكرة القصد الجنائى كما هى معروفة فى القواعد التقليدية فى

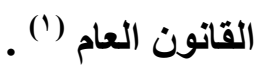

ويعلل هذا بأن للقوانين الاقتصادية من الأهمية مـا يقتضى منتهى اليقظة فى

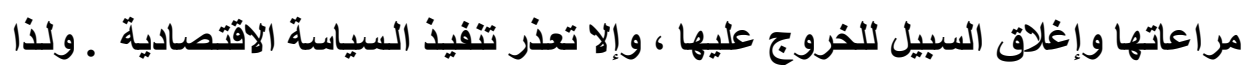
قيل : إن الركن المعنوى فى الجرائم الاقتصادية لـه ذاتيـة خاصـة تميزه عن مثيلـه فى في Très - Moins entendue - الجرائم العادية ، ووصف بأنه أقل شمولا - mince

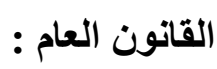

\section{أوجه الخروج عن أحكام الركن المعندى :}

يمكن حصر الخروج عن أحكام الركن المعنوى المقررة فى القانون العام فى

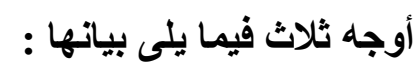

ا. على النق يض مـن قـانون العقوبـات التقليـدى ، الغالـب فـى قـانون العقوبـات

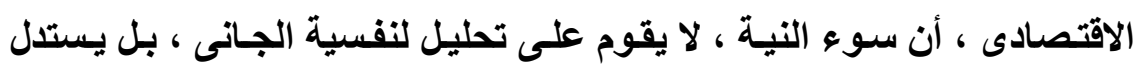

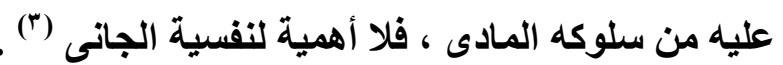

: (1)

Mercadal (B.) : Recherches sur l'intention en Droit penal, Rev. Sc. Crim. 1967 , P. 1, ets.

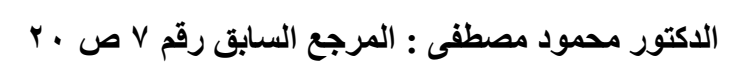

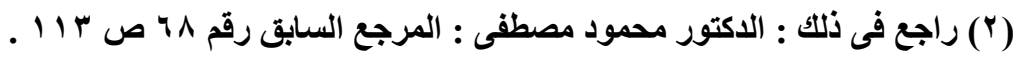
Levasseur : cours de doctrat Précité, P. 193.

Merle et Vitu : Op. Cit., No. 746, P. 598. 
r. ويبدو الخروج عن المبادئ التقليدية فى قانون العقوبات أكثر وضوحا ، عند مـا اعتبر قانون العقوبات الاقتصادى مجرد العلم الواجب توافره للدى الجـانى بعدم مشروعية الواقعة المجرمة مكونا للركن العمدى ('). ويتضح من ذلك أن قانون العقوبـات الاقتصادى يتجه إلى قبول قرينـة الإثم أو الإذناب - Présomption de culpabilité ـ خلافـا للمبدأ التقليدى لقرينـة البراءة . وبالتالى فإن المتهم الأى يفترض فيه قرينة العلم ، ملزم بتقديم الدليل على براعته أو جهله بالقانون ، أو وقوعه فى الغلط ، أى أن هذه القرينة هى قرينة إثبات ، بمعنى أنها تؤدى إلى نقل عبء الإثبات فحسب ، ويكون للمتهم أن ينفيها بكافة الطرق () . ץ. قد يحدث إلا يترك القانون للركن المعنوى أى مكان ، فالحاجة إلى الفعاليـة التى يجب أن يحققها النظام العام الاقتصادى فى قانون العقوبـات تؤدى فى الحقيقة إلى زيادة الجرائم المادية (") . حيث يكفى فى تللك الجرائم توافر الإسناد المادى ، فلا تتوقف المسئولية الجنائية على إثبات الركن المعنوى كما هو الحـال بالنسبة للجرائم الأخرى ـ فبمجرد ارتكاب العمل المحظور ، تنهض المسئولية الجنائية قبل الشخص بحكم الواقع -Ipsofacto- ، بصرف النظر عن القصد (؛) .

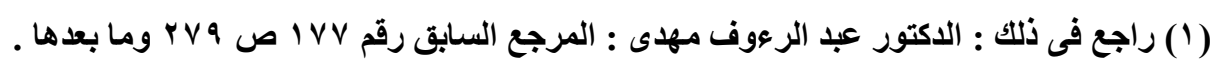

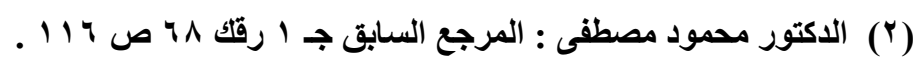

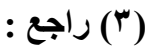

Merle et Vitu : Traité cit. T, 1, No. 464, P. 592 ets. ; Dr. pén. Sp. V. 1, No. 746, P. 598.

Bosly et spreutls : Op. Cit., No. 24, P. 40. 
وتأكيـا لـللك قضت محكمـة النقض الفرنسية بـأن سـوء النيـة ليس ركنـا فى الجريمة التى تتنج من مجرد عدم الملاحظة الإرادى لنص قانونى مفترضسا دائمسا العلم

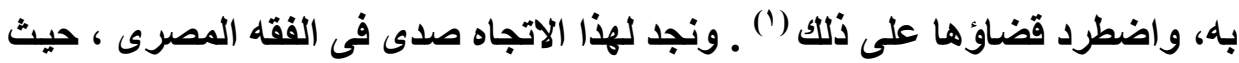
يرى البعض أنها لا عبرة في الجرائم الاقتصادية بـأن يكون الجـانى قد تعمد مخالفـة

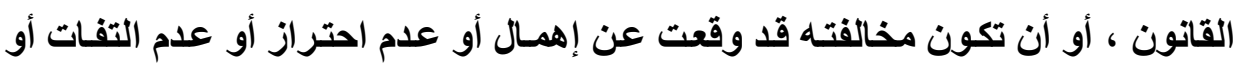

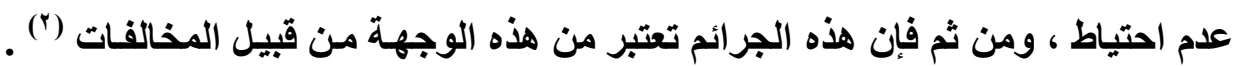
ويذهب رأى إلى أن زيادة هذه الطائفة من الجرائم يستهدف تحقيق مصالح النظام العام الاقتصادى ، ذلك أن الجريمة المادية تستهدف ضمان مراعاة النظام الجماعى(") . والواقع أن افتراض توافر القصد العام فى الجريمـة الاقتصادية ـ كمـا ذهب رأى

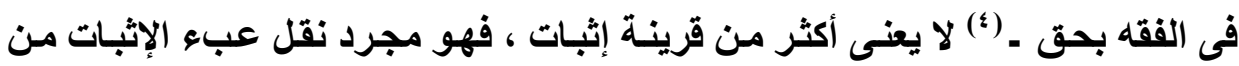
عاتق النيابة العامة إلى عاتق المتهم ، بمعنى أن للمتهم إمكانية أن يثبت أنه لـ لم يخطئ ،

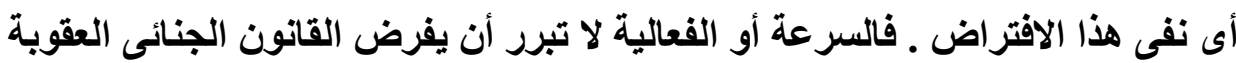

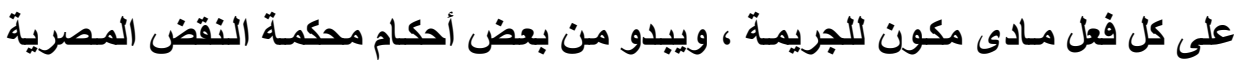
أنها تسير فى الاتجاه المذكور (•)

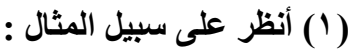

Crim. 27 Mai 1959, B. 279, obs. Légal, Rev. Sc, Crim. 1960, P. 71.

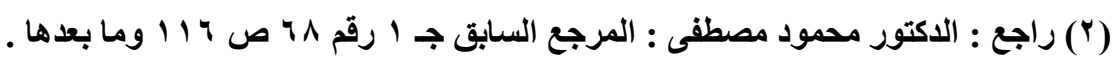

Légal ( A. ) : la responsabilite Sans Faute, in la chambre criminelle et sa jurisprudence, Melanges Patin, cujas 1966, P. 133.

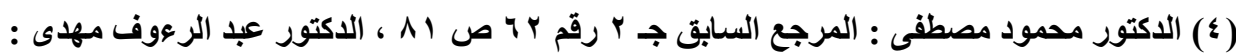

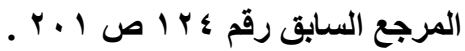

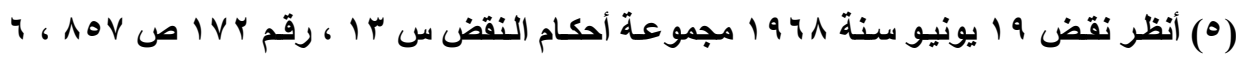

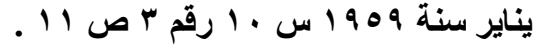


ومن ناحية أخرى إذا كان الغالب فى القانون العام هو تجريم الأفعال الضارة ،

أمسا تجريم الأقعال الخطرة فأمر نادر ، فعلى العكس من ذلتك يظلب فى قانون العقوبـات الاقتصادى تجريم التصرفات التى تعرض المجتمع للخطر ، وهو ما يطلق عليه الجرائم،

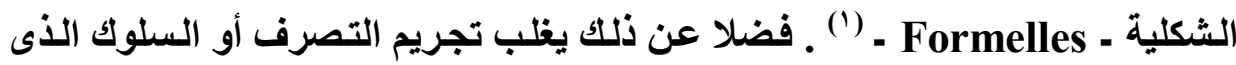

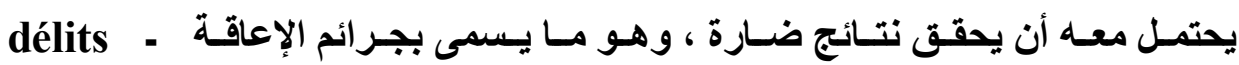

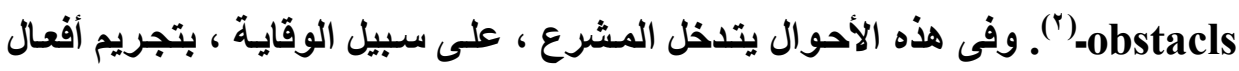
تنم عن خطورة، فيقطع على الجانى السبيل إلى تحقيق الضرر (") ـ وبهذا يتميز قانون العقوبات الاقتصادى عن قانون العقوبات العادى (؛) .

الاتجاه نهو المسئولية الموضومية :

إن تطور قانون العقوبات الاقتصادى لتحقيق فعالية النظام العام الاقتصادى يقود منطقيا إلى عدة نتائج ، فالسائد فى صدد المسئولية عن الجرائم الاقتصادية ، أن تصبح

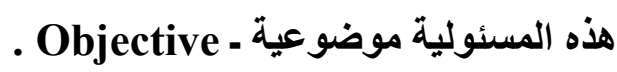

: (1)

Merle et Vitu : Traité de Droit Criminel, Cujas, T. 1, 3 éd. 1978. T. 11, 3 ed. 1979. , No. 461, P. 587 ets. ; spiteri ( J. ) : L'infraction formelle, Rev. Sc. Crim. 1966, P. 497, ets.

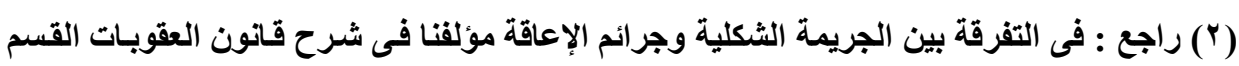

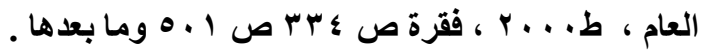

Bosly et Spreutels : art. Précit, No. 35, P. 45; Merle et Vitu : Op. Cit., No. 429, P. 547 ets.

Merle et Vitu : Op. Cit., No. 418, P. 541.

$$
\text { (4) راجع : الاكتور محمود مصطفى : المرجع السابق رقم الף ص } 4 \text {. } 1 \text { وما بعدها . }
$$


غير أن المشكلة الهامـة تتعلق بكيفية تبرير هذه المسئولية ، وفى هذا الصدد اختلف الفقه وتردد القضاء كثير| (') ـو الملاحظ أن هذه المسئولية تستثد ، بشكل مـا ،

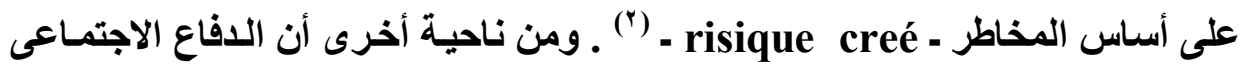
الذى يهاف إلى حماية مصالح المجتمع يستلزم إلا يقدر القاضى الباعث أو الهدف إلا

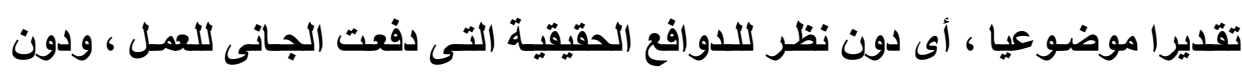
اعتبار الهدف الأى يسعى إليه (") .

وفى هذا الإطار استعاد مبدأ الجهل بالقانون ليس بعذر قوة مطلقة فى القانون ،

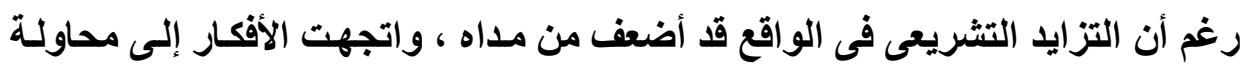

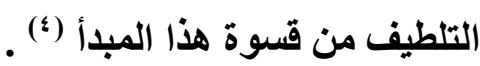
وكنلك الغلط فى القانون قد انتقص من مجاله ، بينمـا التعقيد المتزايد للتنظيم الاجتماعى ، وعدم استقرار النظام العام الاقتصادى تبعا لتغير سياسة الدولة الاقتصادية

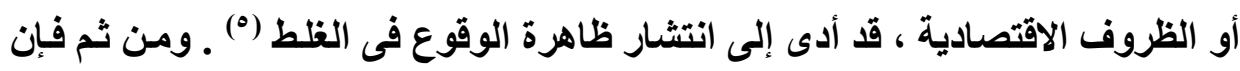
الاهتمام بالمقتضيات الاجتماعية للنظام العام أدى فى كثير من الأحيان إلى التضحية

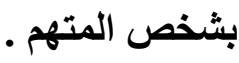

(1) راجع عرض لموقف القضاء والفقه ـ الاكتور عبد الرعوف مهاى : المرجع السابق رقم ؛ YT ص

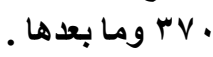

Legal : art. Précité, Melangés Patin, P. 129 ets.

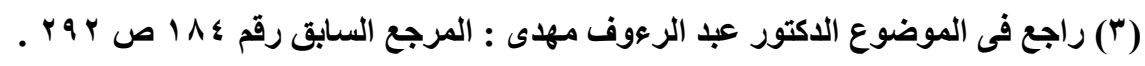

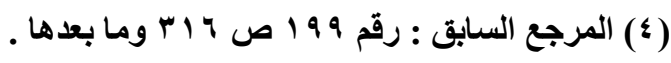

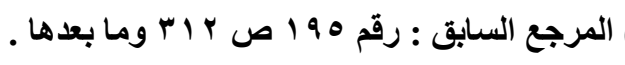




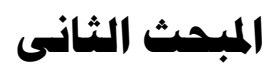

\section{الخروج عن أحكام الإجراءات الجنائية}

تكلمنا فى المبحث السابق عن أوجه الخروج عن المبادئ الأساسية التى يقررها المشرع بثأن جرائم القانون العام ، ولم يقتصر الأمر على ذلك بل امتد الخروج أيضا

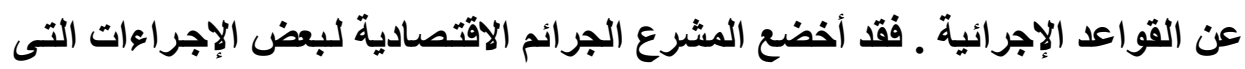

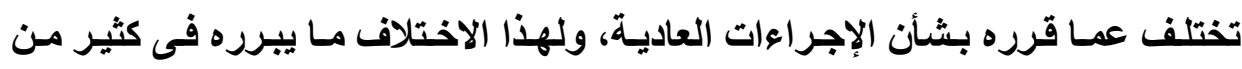
الأحوال ، عندما يكون الباعث على ذلكـ هو الإسـراع وتفـادى البطء اللذى يـلازم الإجراءات العادية ، أو إعداد متخصصين فى البحث عن الجرائم الاقتصادية وضبطها

$$
\text { وتحقيقها ومحاكمة مرتكبها . }
$$

وبطبيعة الحال لن نعرض هنـا المبادئ الأساسية فى الإجراءات الجنائية ، بل

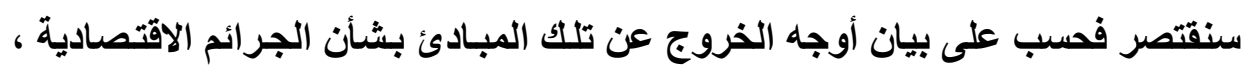

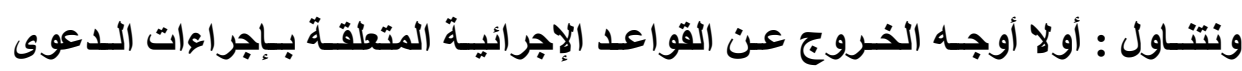

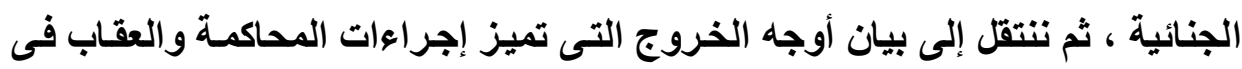

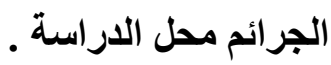




\section{المطاب الأول \\ أوجه الخروج عن الأحكام الخاصة بالدعوى الجنائية}

سـبق أن أوضــنـا أن لـلإدارة سـلطانـا كبيـر ا فيمـا يتعلـق بوضـع النظــام العـام الاقتصادى لقانون العقوبـات ، حيث أن السلطة التنفيذيـة تملكك ، فى بعض الحدود ، سلطة تحديد العناصر المكونة للجريمة ، كما أنها تساهم أيضا بنصيب ملحوظ فى مجـال

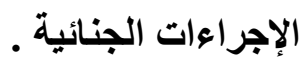

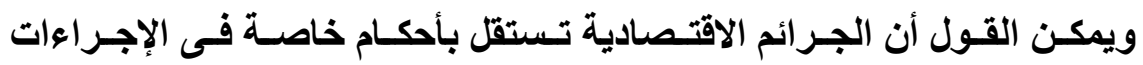

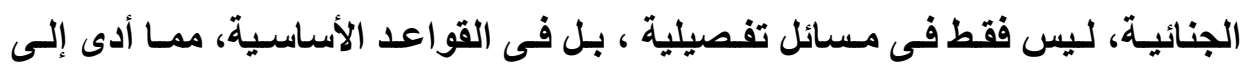
الخروج عن المبدأ التقليدى الخاص بالفصل بين السلطات القضائية والإدارية فى مجـال قانون العقوبات الاقتصادى .

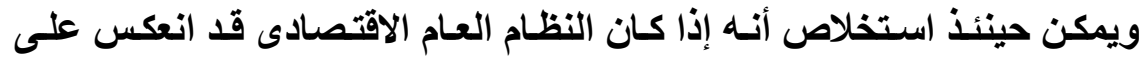
مجال تكوين العقود المدنية بإخراجها من اختصاص القضاء المدنى ، فإنها تخرج كذلك، فى جزء منها ، من اختصاص القضاء الجنائى.

وتلخل الإدارة فى جميع مراحل الدعوى الجنائيـة ، فى إثبات وقوع الجريمـة ، وفى تحريك ومباشـرة الـدعوى الجنائيسة ، ولا يهمنــا فـى الواقع البحث فى الأشـكال

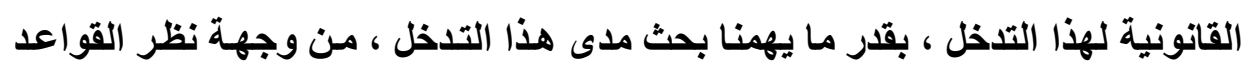
الأساسية. 


\section{الفرع الأول}

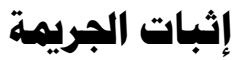

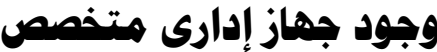

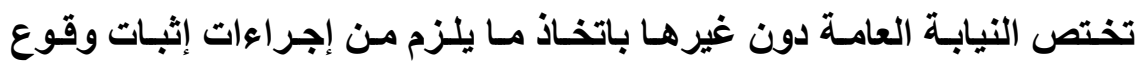

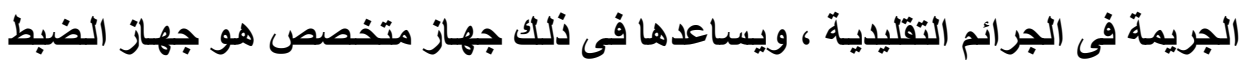

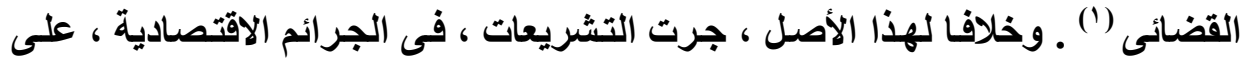

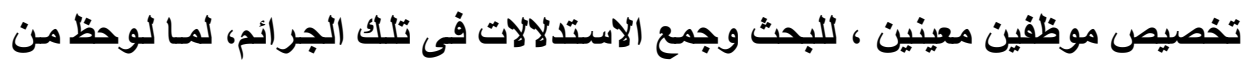

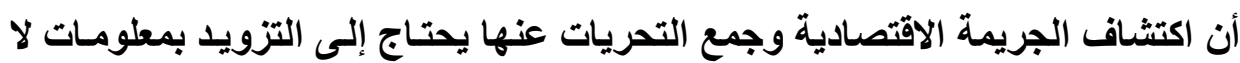

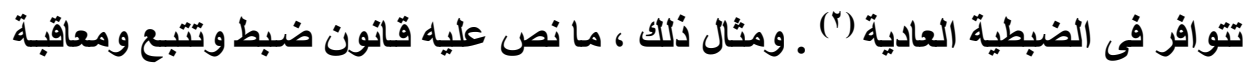

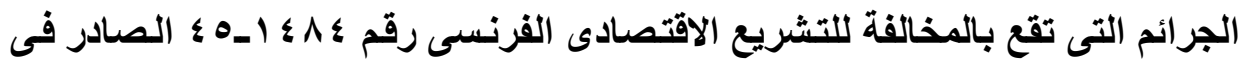

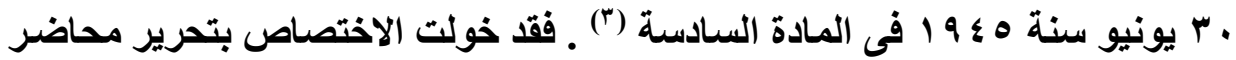

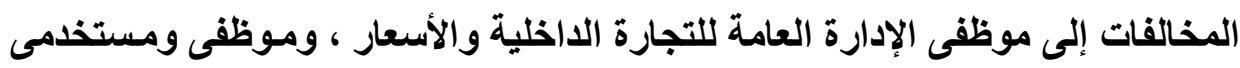

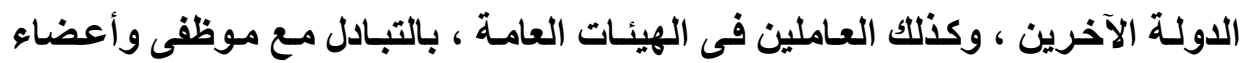

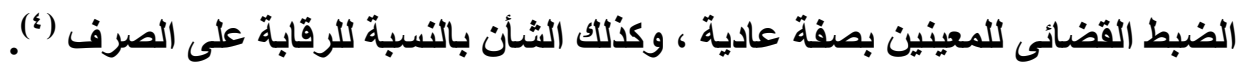

( (1) راجع : رسـالتتا للـكتور اه : المركز القـانونى للنيابـة العامـة ، دراسـة مقارنـة ، جامعة القـاهرة

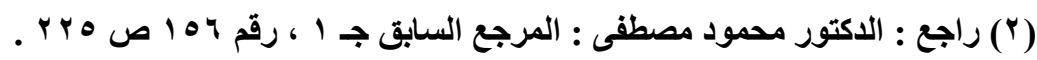

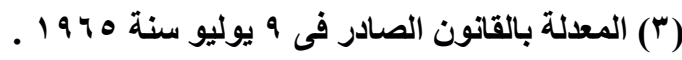

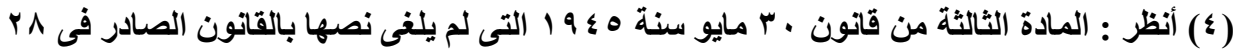

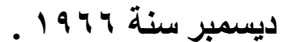

Merle et Vitu : Dr. pén. Sp. V.l, No. 749, P. 599., et No. 908, P. 723 ets. 
وقد اتبع المشرع المصرى هذه السياسة ، فقد حرص على تخصيص موظفين

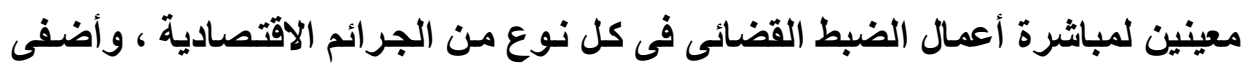
عليهم صفة الضبطية القضائية ، غير أن ذلك لا يعنى منع الضبطية القضائية العادية

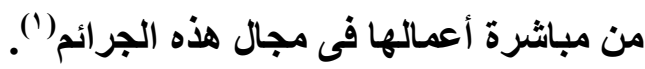
ومن قبيل ذلك مـا نص عليه المشرع فى المسادة V Vمن المرسوم بقانون رقم با 14 لسنة . 190 بثأن التسعير الجبرى وتحديد الأرباح على أن يكون : " للموظفين الذين يندبهم وزير التجارة والصناعة بقرار منه صفة رجال الضبط القضائى فى إثبات الجرائم التى تقع بالمخالفة لأحكام هذا المرسوم بقانون والقرارات المنفذة له " (") .

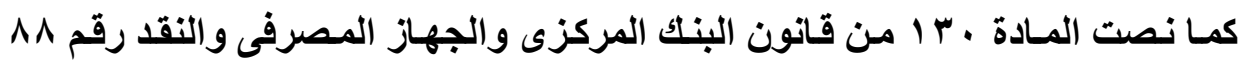

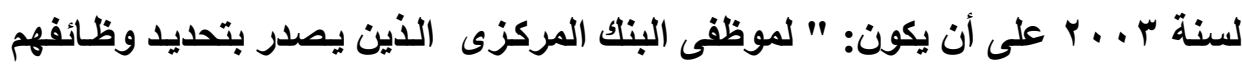

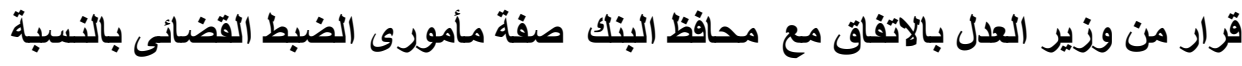
الى الجرائم التى تقع بالمخالفة لاحكام هذا القانون والقرارات الصادرة تنفيذا له وتكون

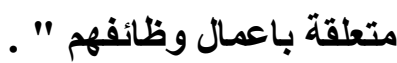
والواقع من الأمر أن وجود جهاز إدارى متخصص يشكل خروجا على الأحكام

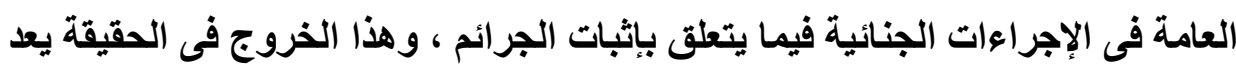

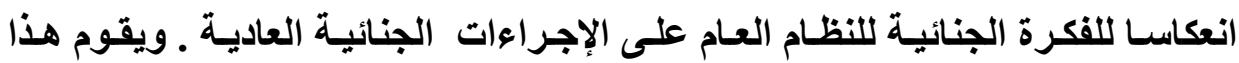
الخروج على اعتبارات ثلاثة هى : ضمان تحقيق السياسة الاقتصادية ، وضمان فعالية الإنية

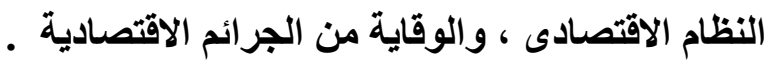




\section{أولا : ضمان تحقيق السياسة الاقتصادية :}

إن الاختصاص الممنوح لبعض موظفى الإدارة فى سبيل إثبات الاعتداءات على إنى النظام الاقتصادى ، يخول السلطات العامة الوسيلة لضمان تحقيق السياسة الاقتصادية .

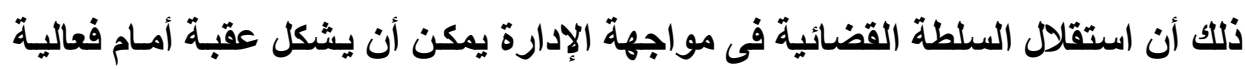
الإجراءات الاقتصادية ـ ذلك أن السلطة الإدارية ، باعتبارها قائمة على تطبيق القوانين

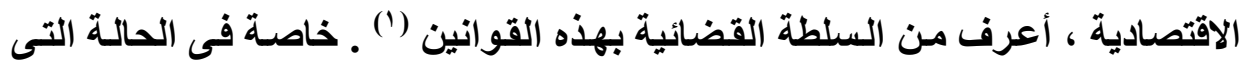

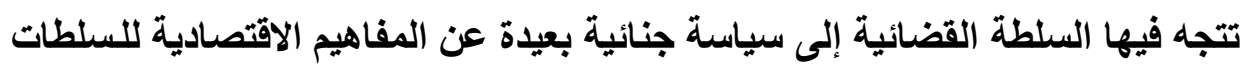
العامة ـ كما وأن الضرورات أو المقتضيات التى تبرر العقاب يمكن ألا تكون هى ذاتها لهابها

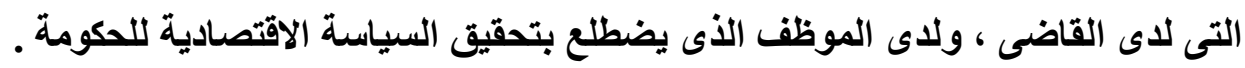
و هكذا يتضح أن تواجد الاختصاص المنافس بين السلطة القضائية والإدارية من شـأنه

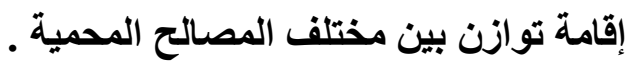
ثانيا : ضمان فعالية النظام الاقتصادى :

غير أنه من جانب آخر ، فإن وجود جهاز إدارى متخصص لإثبات الجرائم

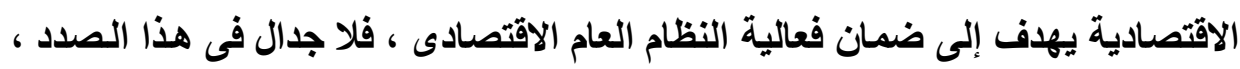

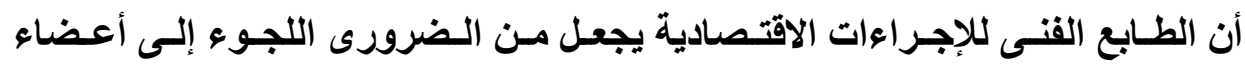

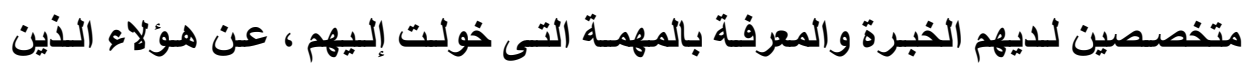

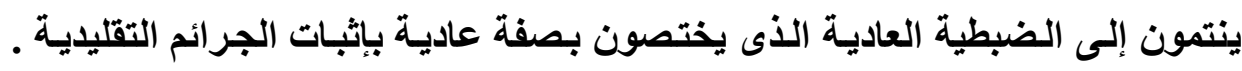

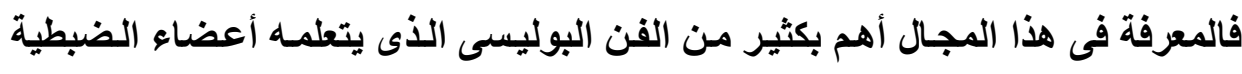

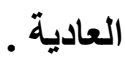


وفى حقيقة الأمر ، يخشى من أعضاء الضبطية العادية ، الذين يقصر عددهم عن سد الحاجة إلى إثبات الاعتداءات التى تقع على النظام العام فى الجرائم التقليدية،

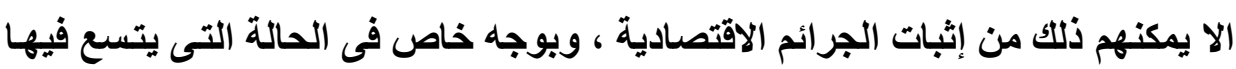
مجال قانون العقوبات الاقتصادى (').

\section{ثالثا : الوقاية هن الجرائم الاقتصادية}

إن وجود بوليس قضائى متخصص ، يعهد إليهه فحسب بالمحافظة على النظام

العام الاقتصـادى ، يمكن أن يكون من شـأنه منـع وقوع الجريمـة أو تكرارهـا ـ ذلك أن الوظيفة التى يضطلع بها البوليس القضائى الخـاص ليست وظيفة قضائية أو عقابية فحسب ، بل أيضا وقائية ، وممارستهم لهذه الوظيفة أجدى فى مكافحة الجريمة أو على لهى الأقل وقف الحالة الإجرامية بسرعة ، دون الحاجة إلى إقامة الدعوى الجنائية ، أو حتى مجرد إخطار النيابة العامة.

وتأكيدا لذلك ذهب البعض من الفقه إلى أن ممارسة دور الرقابة يكون أجدى فى

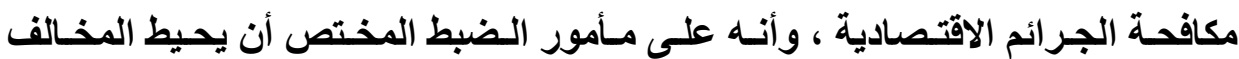
بالنتـائج الضـارة لمخالفتـه التـى تلحق بالمـصلحة الاجتماعيـة الاقتصادية ، ويتعهده بالرقابة فترة من الوقت حتى يعتاد السلوك المستقيم ، ويجب أن يكون فى إمكان مـأمور الضبط القضائى الحصول من القاضسى المـنى على إنذار للمخـالف بأن يسلك سلوكا مستقيما قبل الالتجاء إلى الطريق الجنائى (؟) .

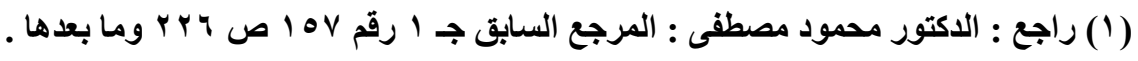

Virj : le droit Pénal Social économique, Rev. int. de dr. pénal, 1953, No. 3, P. 753. 


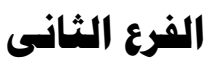

\section{تحريك الدعوى الجنائية}

الأصل أن النيابـة العامـة دون غيرهـا هى السلطة المختصة بتحريك الدعوى

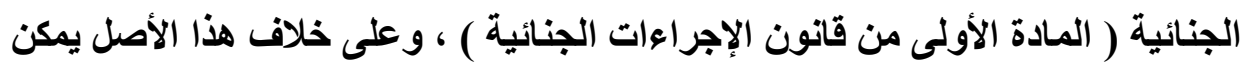

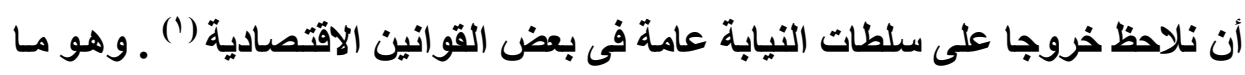

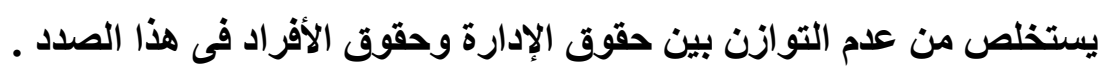

أولا : حقوق الإدارة

إذا كاتت الإدارة تساهم بدور ملحوظ فى وضع نصوص التشريع الاقتصادى

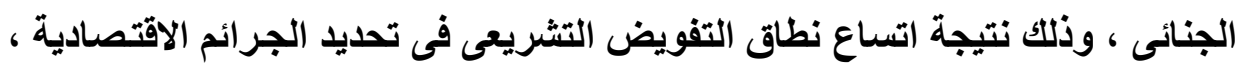

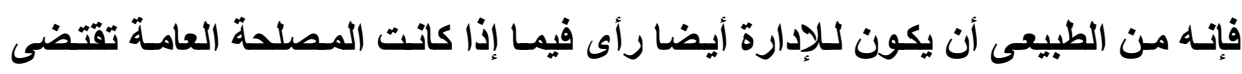

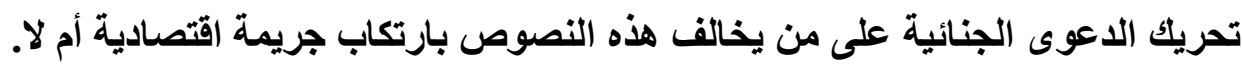

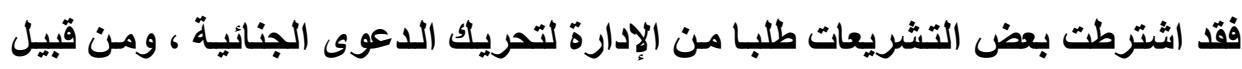

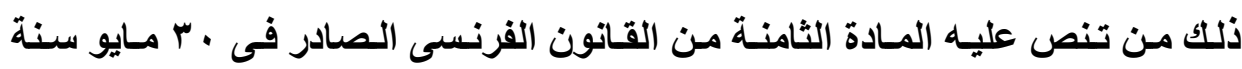

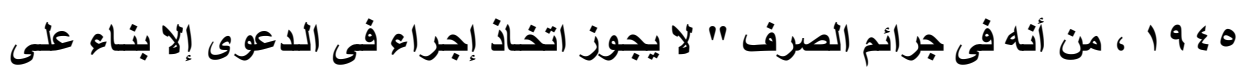

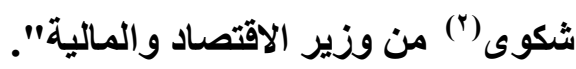

Larguier ( j. ) : L'action Publique Ménaceé, D. 19568, chron. P. 29 ets.

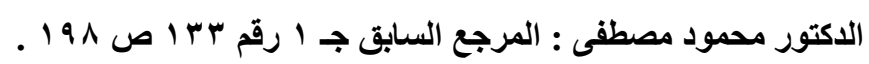

(Y) يلاحظ أن التعبير بالثكوى فى هذا النص غير دقيق ، والمقصود به هو الطلب . 
وعلى هذا جرى المشرع المصرى فى الجرائم التى ترتكب بالمخالفة لقانون

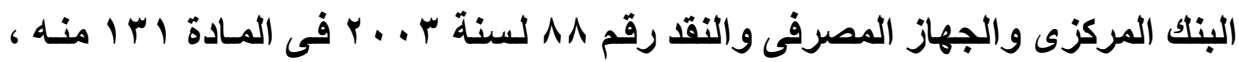
حيث علق رفع الدعوى الجنائية أو اتخاذ أى إجراء من إجراءات التحقيق فى الجرائم

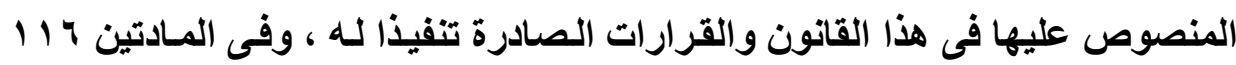
مكرراً و 11 مكرراً (أ) من قانون العقوبـات فى نطاق تطبيق أحكام هذا القانون ، إلا بناء على طلب من محافظ البنك المركزى أو طلب من رئيس مجلس الوزراء ـ (') .

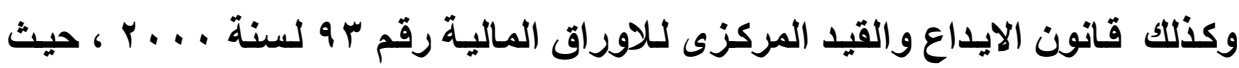
نـص فـى المـادة وه مـن هذا القـانون على انـه " لا ترفع الـدعوى الجنائية بالنسبة للجرائم المنصوص عليها فى هذا القانون الا بناء على طلب كتابى من الوزير المختص

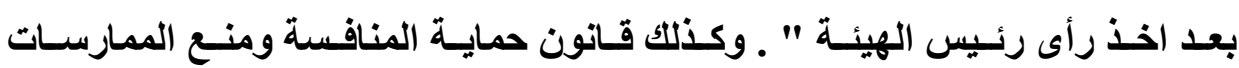

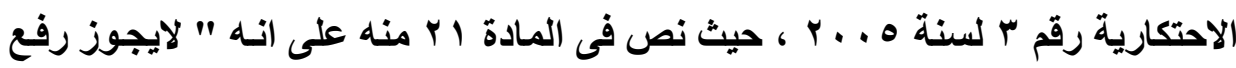

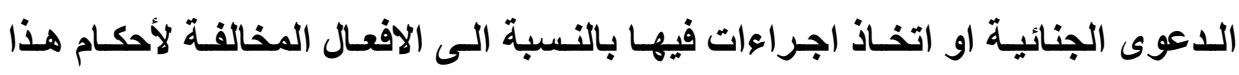
القانون الا بطلب كتابى من الوزير المحتص أو من يفوضه " . والواقع من الأمر أن هذا الحق الممنوح للإدارة ، يتفق وخاصية الملاعمـة التى يتصف بها النظام الاقتصادى فى قانون العقوبات ـ وبمقتضى هذا الدق خولت الإدارة ، بطريق غير مباشر ، سلطة تقدير ملاعمة رفع الدعوى الجنائية ، بتقدير مدى جسامة

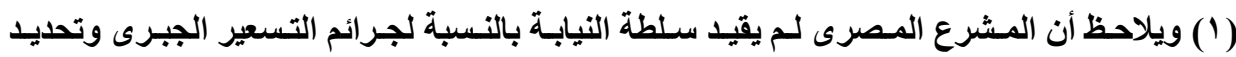

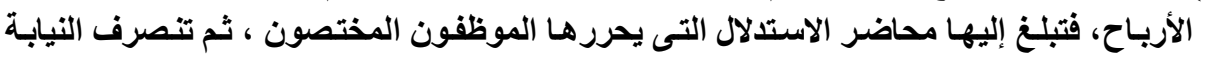

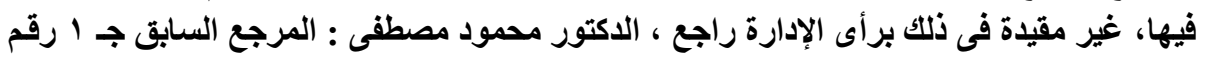
Arا ص r.r. r. 
الضرر الذى يبرر تحريك الدعوى الجنائية (') ـوهو ما يعد استثناء من مبدأ أن النيابة العامة هى الهيئة التى تقوم وحدها بتقدير أهمية الدعوى الجنائية (") .

وللذلك فبإن هذه السلطة تعد سـلاحا خطيرا بيد الإدارة ، يسمح لها بالرقابـة

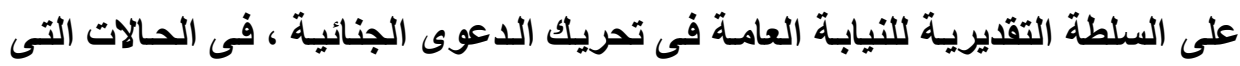

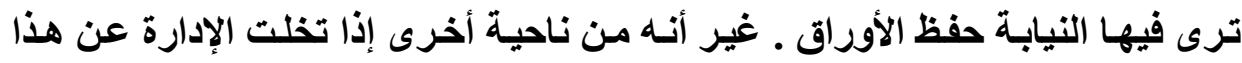

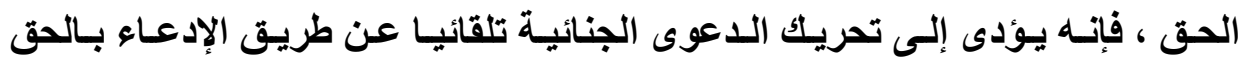

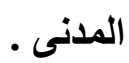
وبالإضافة إلى ما تقام ، يلاحظ أن المشرع الفرنسى ، فضلا عن استلزام تقديم

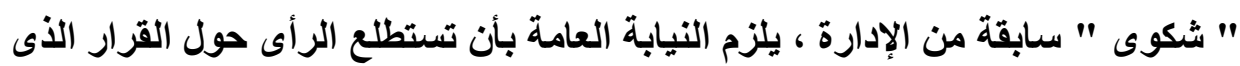

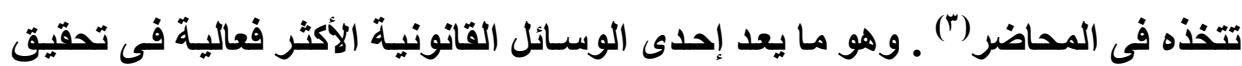

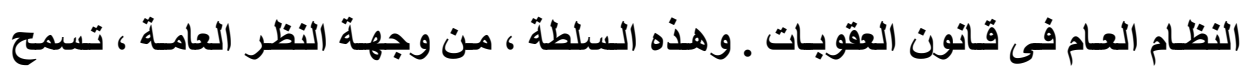
للإدارة أيضا ، بالتوفيق بين اعتبارات السياسة الجنائية ، والسياسة الاقتصادية تبعا لظروف الحسال ـ فباذا كانت الظروف الاقتصادية لا تستلزم توقيع عقاب جنائى ، فبان الإدارة يمكنها أن تغض النظر عن الجرائم التى ترتكب ، وتقتصر على مجرد توجيه

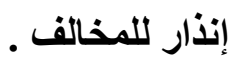

(') (1) (1)

Savatier ( R. ) : chorn. Précité, P. 41. D.

: (ץ) : راجع فى هذا المبدأ

Clerc ( Francois ) : Opportunité ou légalité des Poursuites ? ; Rev. Pén. Suisse, No. 3, 1982, P. 276. Ets.

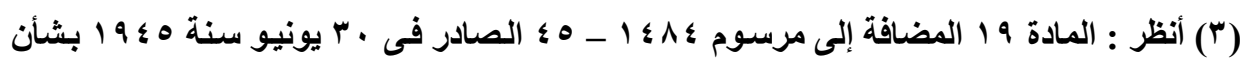

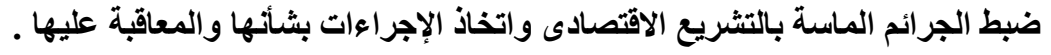


خلافا لألك إذا كاتت الظروف الاقتصادية تستلزم اللجوء إلى علاج حاسم ، فبان

الإدارة لا تتردد فى اتخـاذ الإجراءات القضائية فى الجرائم المكتشفة ـ ويجوز كذلك ، عـن طريـق البـوليس القـضائى المتخـصص ، البحـث عـن نـوع محـدـ مـن الجـرائم الاقتصادية لاكتثافها"') ومن ثم تتحقق فكرة أن السياسة الجنائية تهدف إلى تحقيق

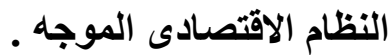

غير أن من ناحية أخرى ، يلاحظ أن تخويل الإدارة ، بصفة استثنائية ، سلطة علدم الإبلاغ عن المخالف ، يسمح لها بالتوفيق بين قسوة الاقتصاد الموجهه والحسالات الفردية ، أى أنها تجرى تفريدا . وهناك ثمة اعتبارات مختلفة ، يقوم عليها تقدير السلطة الإداريـة التى تضطلع بالتصرف فـ محضر التحقيتق ، إمـا على أســاس المصالح أو الفوائـــ المتحققة ، أو العود، أو الأهمية الاقتصادية للعقد المتنازع عليه ـ والواقع أن التفريد الإدارى للجزاء الجنائى يتطابق تماما مع مرونة النظام العام الاقتصادى الموجه (†) .

(1) مثال ذلك : مراقبة بطاقات البضائع المعروضة - Etiquettes aux étalages ـ في فترات الإت تثبيت

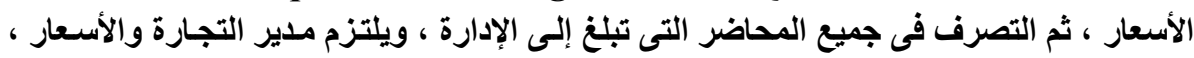

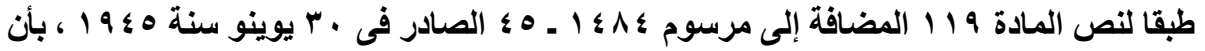

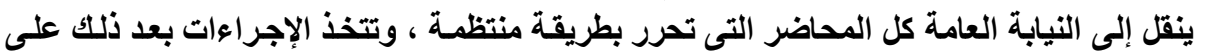

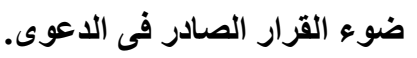

Savatier ( P. ) : Chron - Précité No. 40. 


\section{سلطة النيابة العاهة فى تقدير الطلب}

يثار التساؤل فيما إذا كان يتعين على النيابة العامـة أن تحرك الداعوى الجنائية

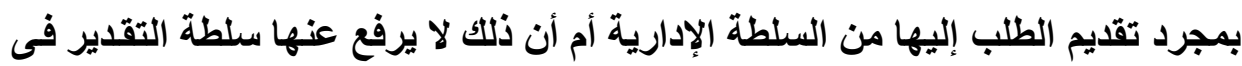

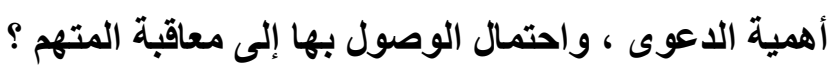

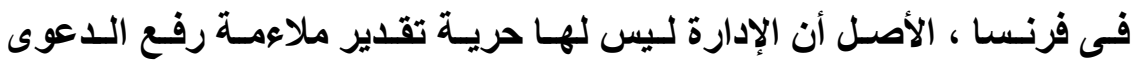

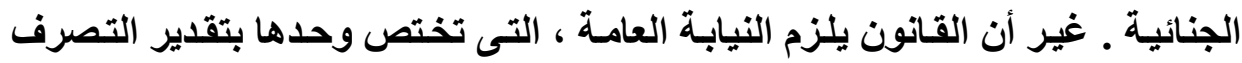
القضائى الذى ترى ملاءمته فى الدعوى ، أن تخطر الإدارة بالقرار الذى اتخذته فى النى الدعوى ، وذلك خلال خمسة عشر يومـا من استلامها المحضر ـ وفى حالات التلبس تبلغ المحاضر مباشرة للنيابة العامة ، وعليها كذلك أن تخطر الإدارة بها لتبدى رأيها

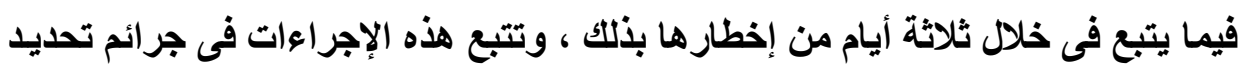

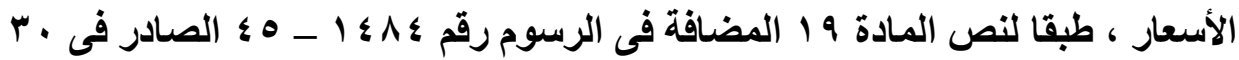
يونيو ـ ولهذا الحق أهمية كبيرة ، إذ يسمح لمدير التجارة الداخلية والأسعار أن يقدم

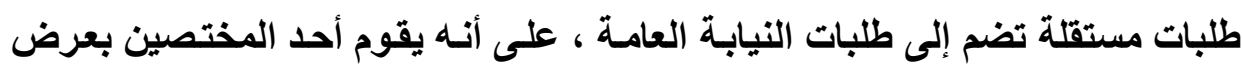
وجهة نظر الإدارة أمام القاضى (')

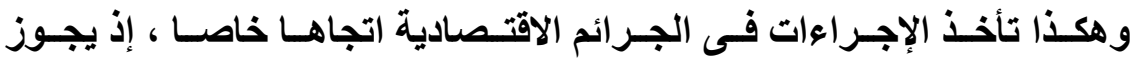

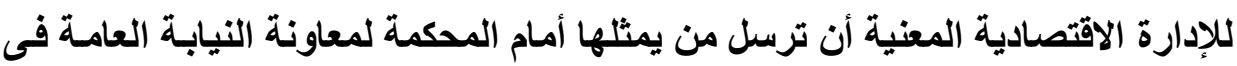

Costa ( J. l. ) : art. Précité, P. 115; Merle et Vitu : Op. Cit., No. 918, P. 729. 
أما فى مصر ، فالذى يمتنع على النيابة العامة هو تحريكها الدعوى بغير طلب ، غير أن الطلب لا ينتص من سلطتها فى تقدير تو افر عناصر الجريمة ، وقيام أدلة كافية

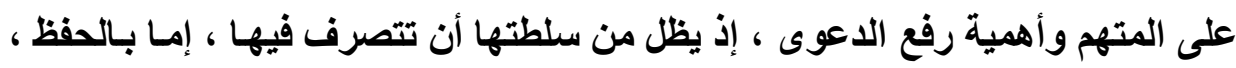
وإما بإصدار قرار بعدم وجود وجه لإقامة الدعوى الجنائية ، وإما بتحريكها غير متقيدة

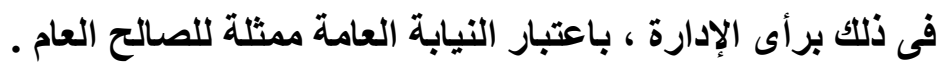

\section{ثانيا : حقوق الأفراد}

يثار الجدل حول مـا إذا كان يجوز للمدعى بـالحقوق المدنية أن يحرك الدعوى

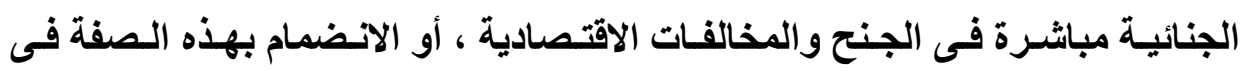
الاعاوى المقامة بمعرفة النيابة العامة ؟ الجنائ

نصت المادة ؛ من قانون المحاكم الاقتصاية الصادر بالقانون رقم • ب ا لسنة

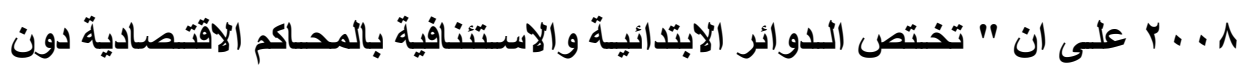

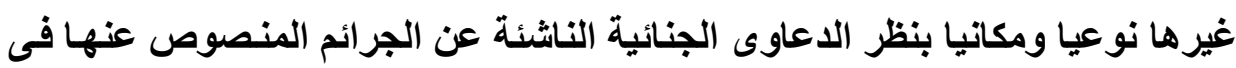

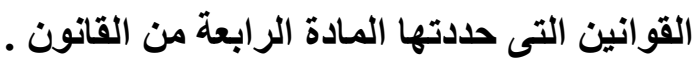

ممـا مؤداه انـه لا تقبل اللدعوى المدنية التبعية امـام المحـاكم الاقتصاية نظرا

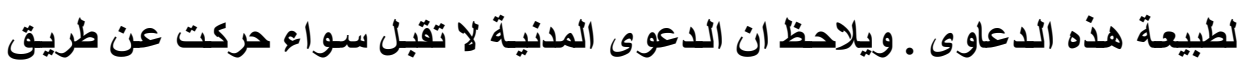
الادعاء المباثر او عن طريق التذخل امام المحكمة الجنائية اثناء نظر الدعوى . وقد جرى قضاء الدائرة الجنائية لمحكمة النقض الفرنسية منذ سنة اسبو 19

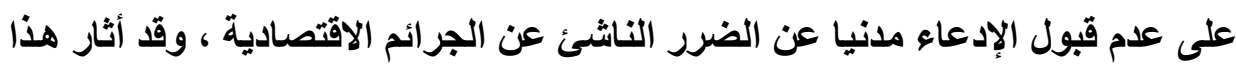

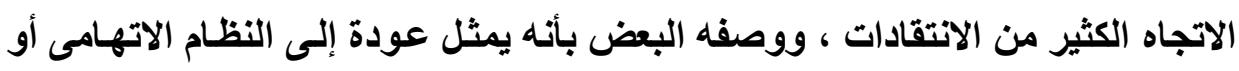

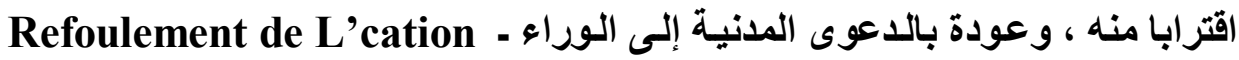


مال civile عليها (r) (ن)

\section{تشريك الدعوى الجنائية بالطريق المباشر :}

أسست محكمة النقض الفرنسية قضاءها (") ـ فى تقيــ حق الأفراد فى تحريك

الاعوى الجنائية على حجة أساسية مضمونها أن : " الضرر الذى ينشأ عن الجرائم الاقتصادية ، لا يصيب فردا ، و إنما يلحق المصلحة الاقتصادية ، التى هى من المصالح

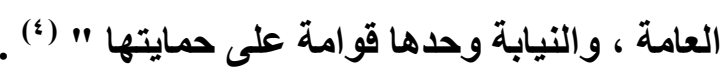

وفى هذه الحجـة مـا يـوحى بـالتمبيز بين وظيفتى قـانون العقوبـات ، فالائرة

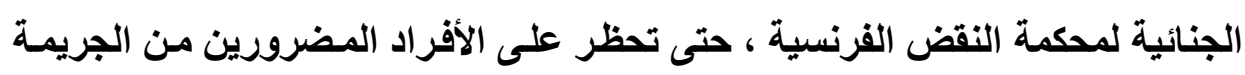

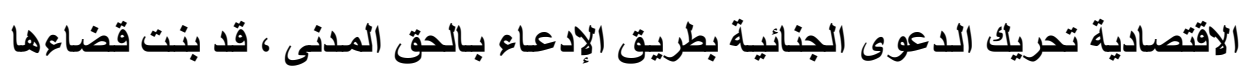

: (1)

Vidal ( J. ) : Obsrevations Sur la nature juridique de L'action civile, Rev. sc. Crim. 1963, P. 480 ets.

$$
\text { : (r) راجع فى عرض هذا الحجج والرد عليها (r) }
$$

Hartemann ( luc. ) : L'action civile et les infractions à la législation éconmique aprés la loi Royer, Rev. sc. Crim. 1976, No. 13 ets., P. 335 ets.

Crim. 19 nov. 1959, D. 1960, 463, note Durry. ; J.C.P. 1960, 11, 11448 note chambon ; 19 Avr. 1961. J.C.P. 1961, 11, 12968; 11 Juill. 1962, D. $1962,597$.

(؛) وقد أيدت كثير من المحاكم الجزئية فى فرنسا أيضا اتجاه محكمة النقض الفرنسية فى هذا الصدد :

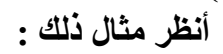

Paris 7 fév. 1961, G.P. 61, 1, 110. 
على أن قـانون العقوبـات الاقتصادى إنـــا يضطع بوظيفة حمايـة مصالح المجتمع .

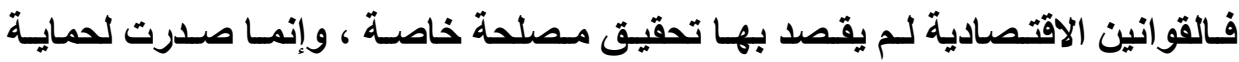

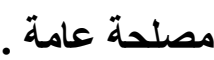

غير أن حرمان المدعى المدنى من حق رفع الدعوى المباشرة لا يغنى حرمانه من حقه الشرعى فى تعويض الأضرار التى لحقت بـه ، بل يجوز لـه أن يقيم دعواه الهاه

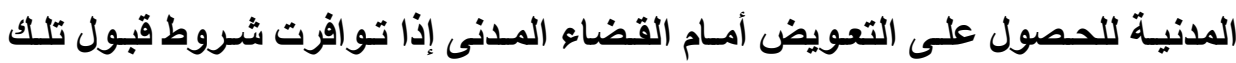

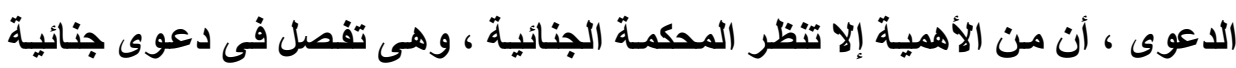

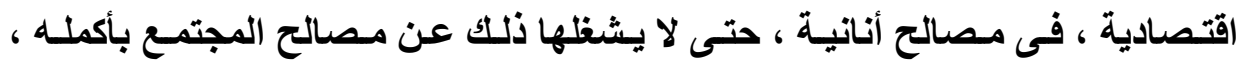
و الدولة وحدها هى الحارس الطبيعى للمصالح الاقتصادية ـ وبناء على ذلك إذا كانت

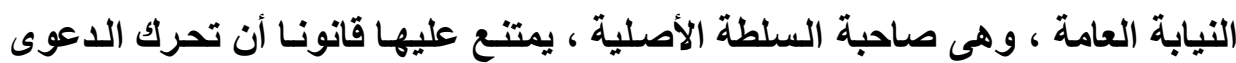

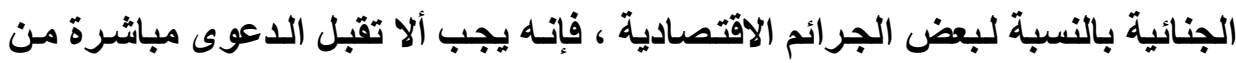

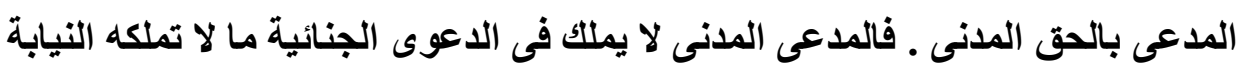

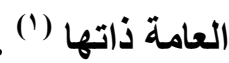

والو اقع أن قضاء محكمة النقض الفرنسية يثير بحثـا على جانب كبير مـن

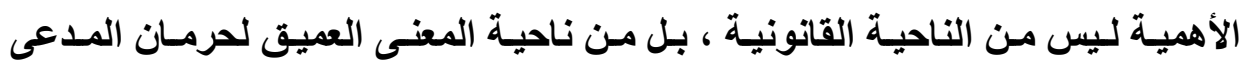
المدنى من حق تحريك الدعوى الجنائية بطريق الإدعاء بالحقوق المدنية . فقد كان لهذا القضاء أهميته فى توجيه النظر إلى ذاتيـة النظام العام الاقتصادى

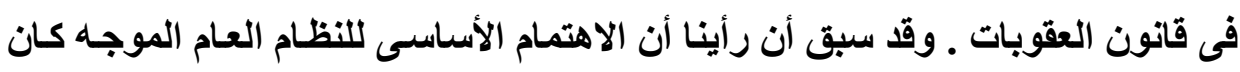

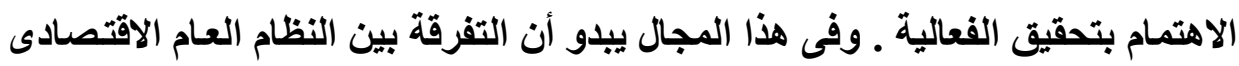


التوجيهى والنظام العام الاقتصادى للحمايـة ، قد فقدت كثيرا من أهميتها فى الوقت

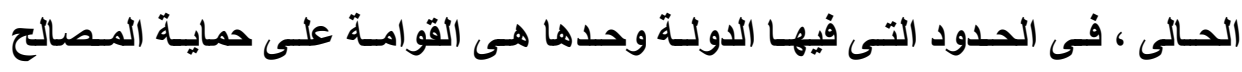

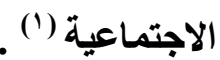

ولذلك يقال أنه لم يثبت أن اشتراك المدعى المدنى فى تحريك الدعوى الجنائية

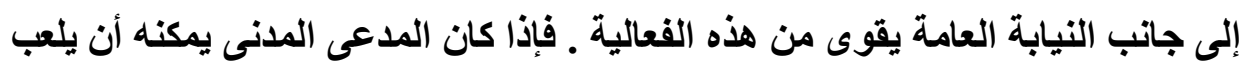

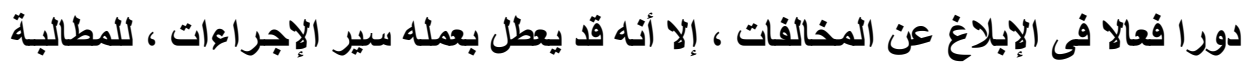

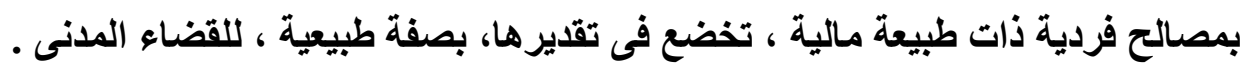

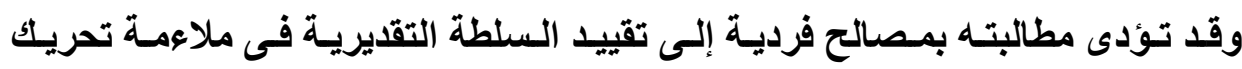
الاعوى الجنائية، بتحريكه هذه الدعوى ضد رغبة الإدارة والنيابة (")

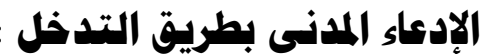

لم يقتصر قضاء محكمة النقض الفرنسية على القضاء بعدم قبول الدعوى

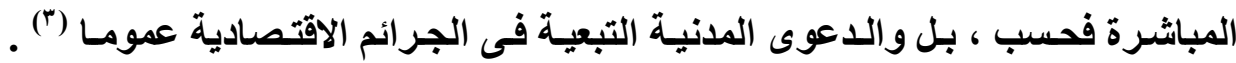

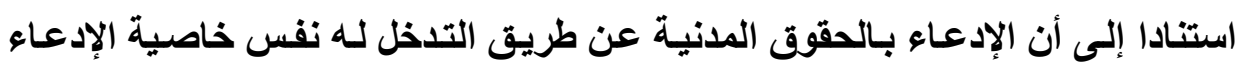

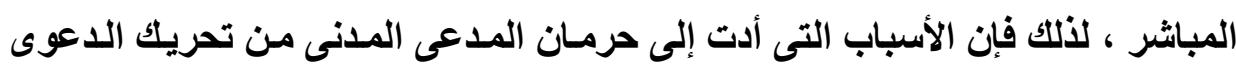

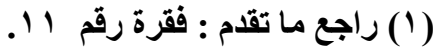

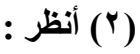

Merle et Vitu : Traité Précitée, T. 11. No. 894, P. 92 ets. Et No. 915, P. 117 ets.

Crim. 8 Déc. 1906, D. 1907, 1, 207, Rap. Laurent - Althalin. 
الجنائية بطريق الإدعاء المباشر يتعين أن تؤدى أيضا إلى عدم إقامـة دعوى مدنيـة

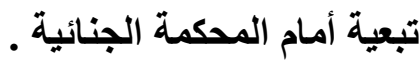

وعلى ذلك يتضح ، أن ذاتية النظام العام الاقتصادى فى قانون العقوبات ليست فحسب الأسساس الذى بنت عليهه محكمة النقض الفرنسية رفض اللـعوى المدنيـة

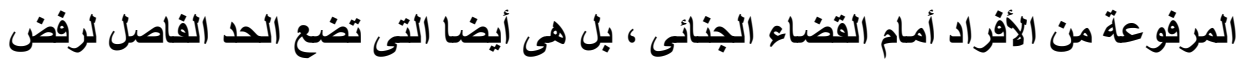

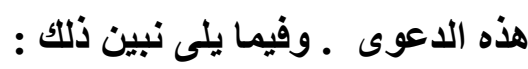

\section{أساس رفض الدعوى المدنية فى المواد الاقتصادية :}

أن ذاتية النظام العام الاقتصادى فى قانون العقوبات هى الأساس الذى بنت عليه

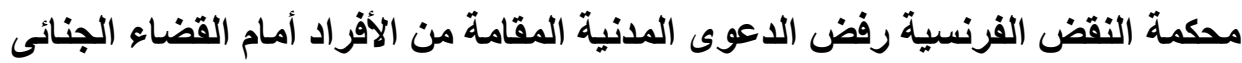

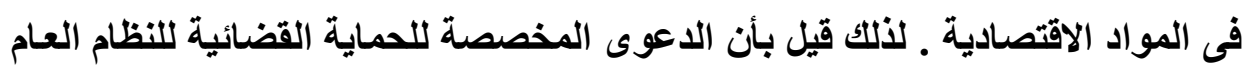

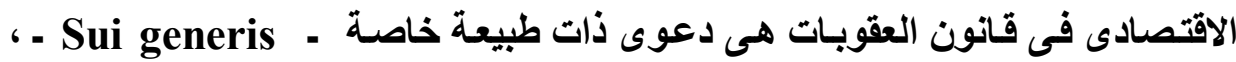

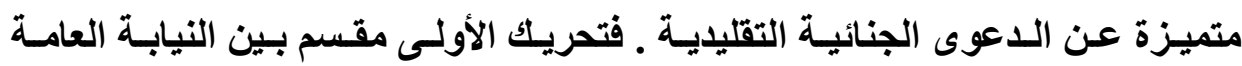

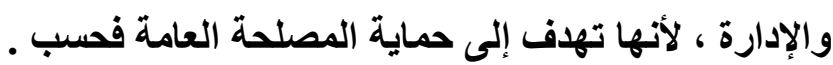

أما الاعوى الثانية فمقسمة بين النيابة العامة ، والمجنى عليه ، لأنها تهذف إلى الى التئي

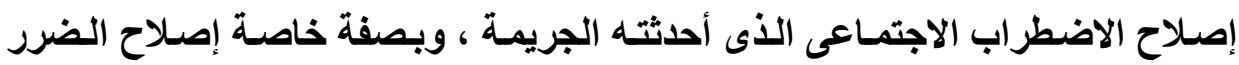

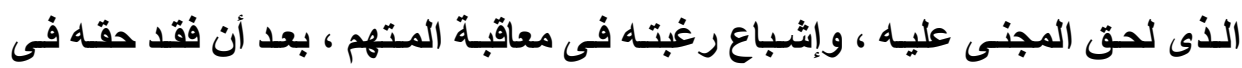

Vidal : Art. Précité, P. 480 ets.

Vr مجلتة البحوث القانونيتَ والإقتصاديت 
وعلى ذلك وصفت دعوى حماية النظام العام الاقتصادى فى قانون العقوبات ،

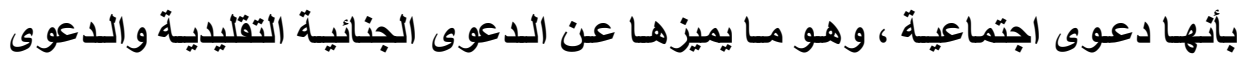

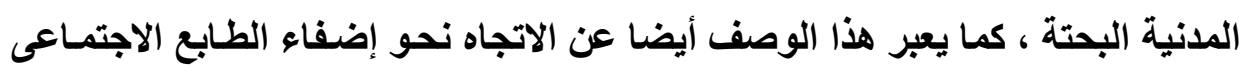

\section{الهد الفاصل لرنض الدعوى المدنية :}

إن ذاتية النظام العام الاقتصادى فى قانون العقوبات هى التى تضع أيضا الحد

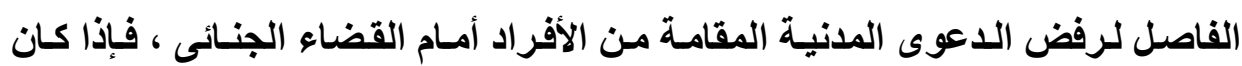

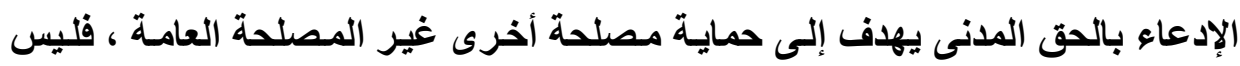
أمام المدعى المدنى للحصول على حقوقه إلا الطريق المدنى (') .

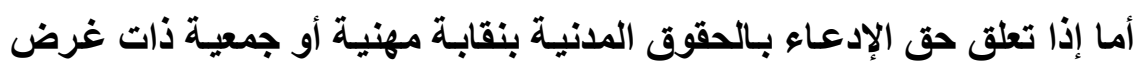

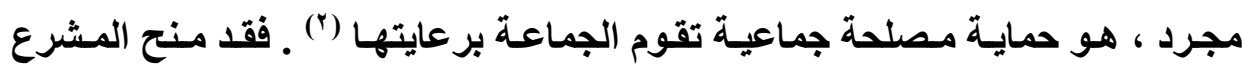

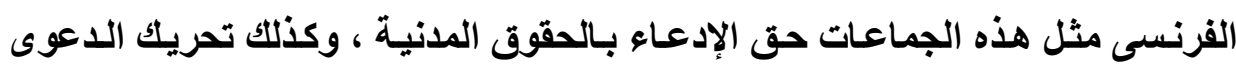

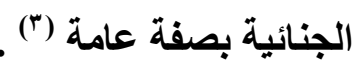

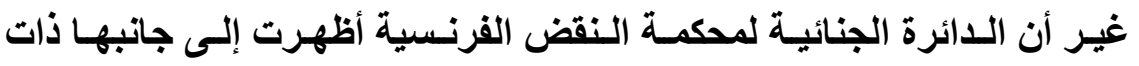

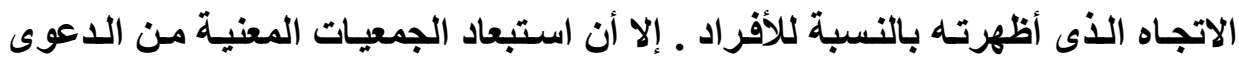

Stefani, levasseur et Bouloc : Prcoédure Pénale, Dalloz, 1984, No. 179 ets., P. 200 et s.

Ibid : No. 179, P. 200 ets., et 186, P. 210 ets. 
الجنائية الاقتصادية لم يكن مستندا إلى ذات المبررات التى بنى عليها حرمـان الأفراد

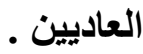

أن فكرة المـلحة الجماعيـة تتميز عن فكرة المـصلحة الفرديـة ، والقاضسى الجنائى لا يخثى إلا المصالح الأنانية التى تثوه ذاتية النظام العام الاقتصادى فى قانون العقوبات ـ لذلك فقد أثار قضاء الائرة الجنائية لمحكمة النقض الفرنسية التساؤل عن أسباب حرمان الجماعات التى تهذف إلى الدفاع عن غرض مشابه لذلكات الذى تهذف إليه

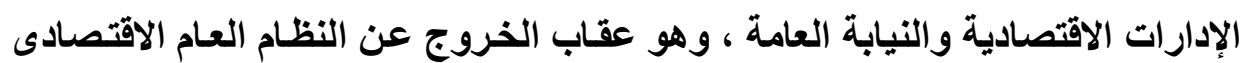
فى قانون العقوبات .

غير أن المشكلة التى تثار هى ما المقصود بفكرة المصلحة الجماعية التى تدعى الجماعات الدفاع عنها ، هل هى متميزة عن المصلحة العامة التى تضطع بحمايتها

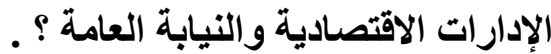

لقد ترددت الدائرة الجنائية لمحكمة النقض الفرنسية فى هذا الصدد ، بل أن أحكامها أحيانا كانت متعارضة ـ وأثار المعيار الذى وضعته الكثير من الاتثقادات ، بل أن الأخذ به ، أصبح شبه مستحيل ـ فهو إما أن يؤدى إلى إغلاق طريق الدعوى المدنية

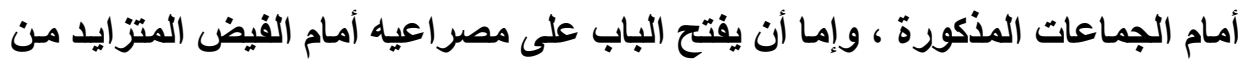

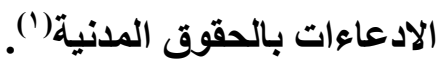

$$
\text { (1) (1) رجع فى هذا التطور : }
$$

Stefani, levasseur et Bouloc : Op. Cit., No. 179, P. 200 ets., Merle et Vitu : OP. Cit., T. 11, No. 889, P. 698. 
وهذا هو موقف محكمة النقض الفرنسية ، ولقد سـايرها فى ذلك الرأى السائد

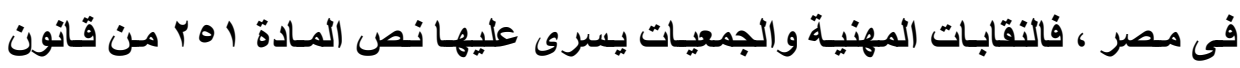

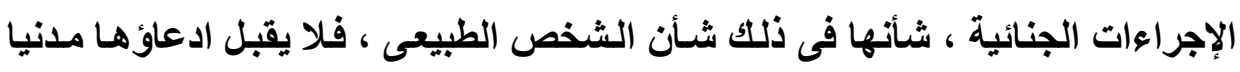
بحجة المساس بمصلحة جماعيـة لأن الضرر يكون غير مباثر ، ولأن النيابة العامـة الفانة

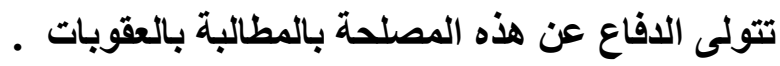
والواقع من الأمر أن هذا الاتجـاه منتقد (') ، ويؤخذ عليهه أنـه يقصر حمايـة النظام العام الاقتصادى فى قانون العقوبـات على الإدارات الاقتصادية والنيابة العامـة الإنة فحسب ـ ويمكن القول أن الاعتراف الواسع بحق هذه الجماعات فى الإدعاء بـالحق

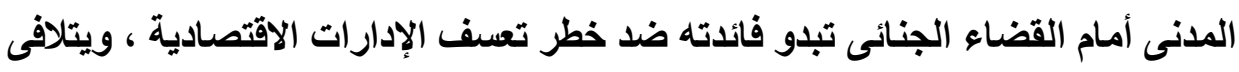

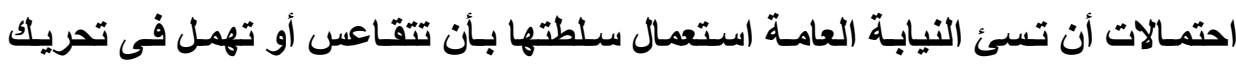

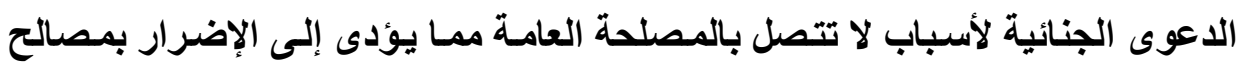

$$
\text { الدولة. - الاعكي }
$$

لذلك يجب أن تخول هذه الجماعات حق الإدعاء مدنيا ، كما هو الثأن فى بعض

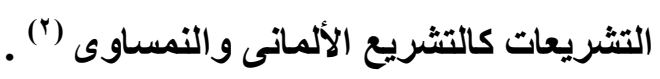

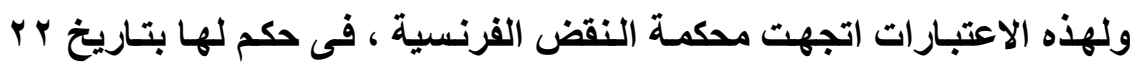

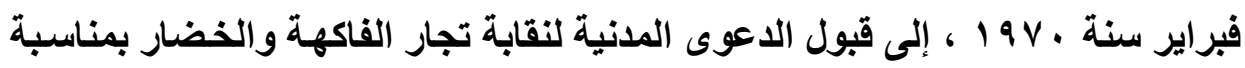

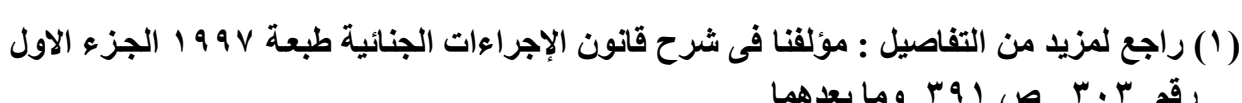

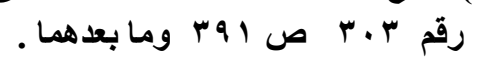

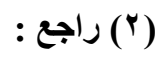

Merle et Vitu : Op. Cit., No. 920, P. 125. 
الاعوى المقامة عن جريمة تنظيم أسواق ذات مصلحة وطنية (') ـوقد أحدث هذا الحكم

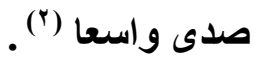

ثم أكدت محكمة النقض الفرنسية قضاؤها فى سنة 19 V ا فيمـا يتعلق بدعوى

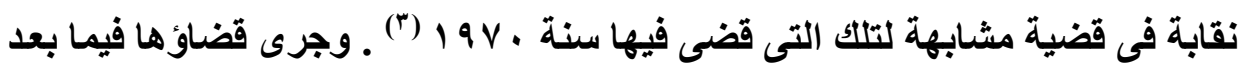
على أن للنقابات المهنية أن ترفع دعواهـا المدنيـة سواء أمسام المحساكم المدنيـة أم أمسام المحاكم الجنائية ، بل ويمكنها الإدعاء بحقوق مدنية أمام قاضى التحقيق ، إذا ما ترتب

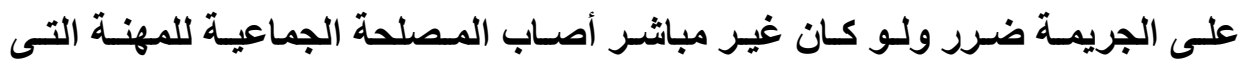

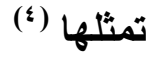

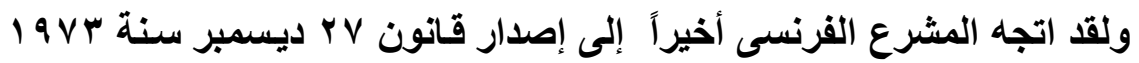

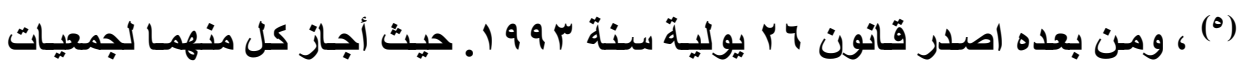
المستهلكين بالإدعاء مدنيا وتحريك الدعوى الجنائية والمدنية فى الوقائع التى تتضمن

D., 1970, 166, rapport costa, J.C.P. 1970, 11, 13626 note Guérini ; G.P. 70, 1, 258, note Duguet, Rev. tr. Dr. civ. 1970, 363, obs. Durry.

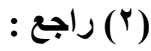

Guilberteau ( M.me) : la recevabilité de l'action Syndicale en matiére d'infraction économiques, Rev. Sc. Crim. 1973, P. 633 ets.

Crim. 16 Juin 1973, B. 279.

Stefani. Levaasur et Bouloc : Op. Cit., No. 179 ets., P. 200 ets.

Calais-Auloy : la loi Royer et les consomateurs, D., 1974, chron, 91 ets. 
ضررا مباشرا أو غير مباثر للمصلحة الجماعية للمستهلكين ( المـادة خ ؛من القانون الأول ، والمادة ا Y ع ـا من القانون الأخير) ـ ويلاحظ أن حق هذه الجماعـات لا يقتصر فحسب على مجال الأسعار ، بل يمتا إلى كل المجال الاقتصادى بالمعنى الواسع .

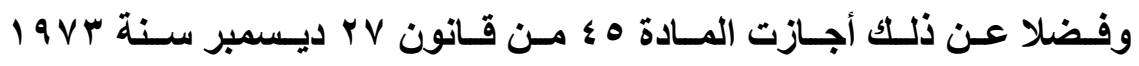
للأشخاص الطبيعين بممارسـة الدعوى المدنية بتعويض الأضرار الناشئة عن جريمـة

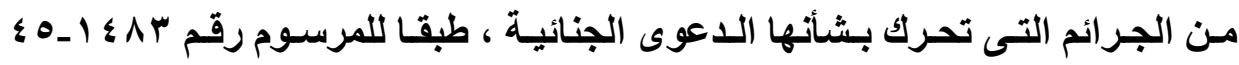
الصادر فى · ب يونيو سنة ه ؛ 9 1 بشأن تحقيق واتهام وعقاب الجرائم الاقتصادية ، على أن يكون ممارسة هذه الدعوى المدنية طبقا للشروط العامة ـ وقد يثار التساؤل هل ستستمر محكمة النقض الفرنسية فى تأكيد أن الجرائم الاقتصادية تستهرف حمايـة

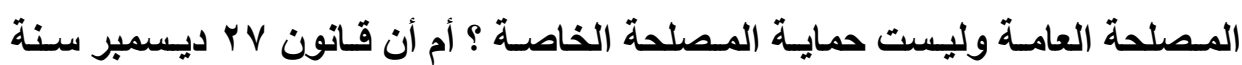

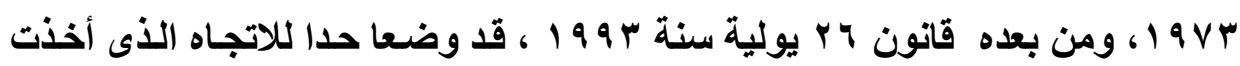

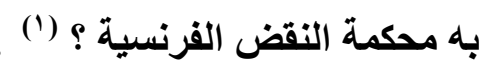
الواقع أنـه لا يمكن القـول بــلكك ، إذ أن كل مـن القـانونين بإخضاعه ممارسـة

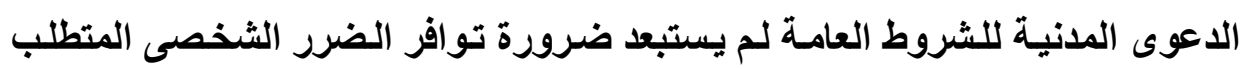
لقبول الدعوى المدنية من المجنى عليه فى الجريمة . وحقيقة الأمر أن الحد الفاصل فى قبول أو رفض الدعوى المدنية فى الجرائم الاقتصادية يرجع إلى مدى تحقق ضرر عن الجريمـة الاقتصادية يمكن أن يلحق بأحد الأفراد

Merle et Vitu : Dr. Pén. Sp, OP. Cit., V,I, No. 918, P. 729 ets. 


\section{الضرر الذى ينشأ عن الجريمة الاقتصادية :}

قدمنا أن قضاء محكمة النقض الفرنسية جرى على التفرقة ، بين النصوص

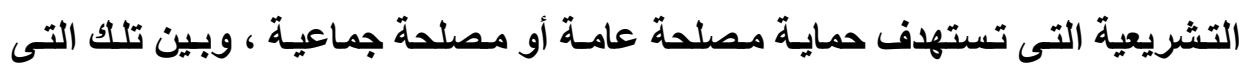

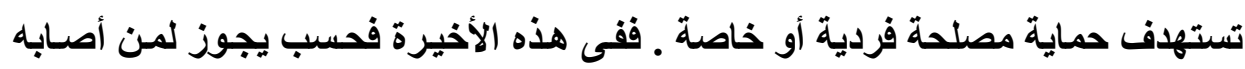

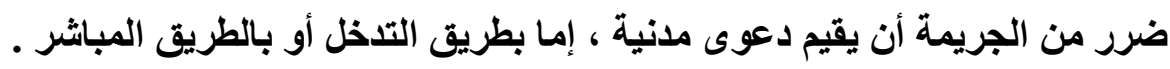

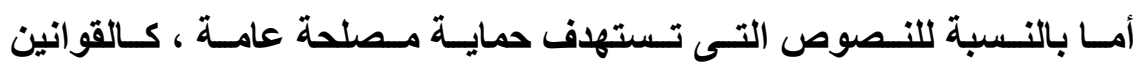
الاقتصادية ، فهذه النصوص لم يقصد بها تحقيق مصلحة خاصة ، وإنما صدرت لحماية

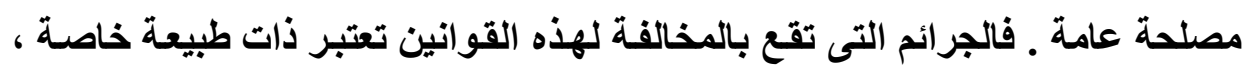

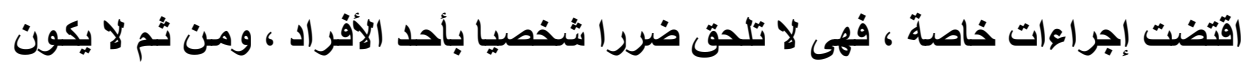

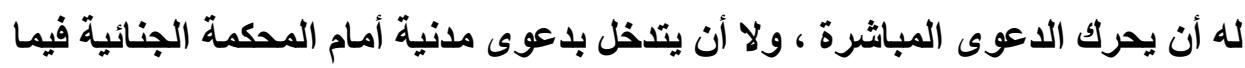

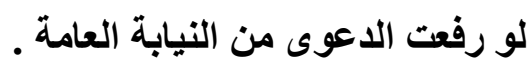

و الواقع أن التفرقة التى أجرتها محكمة النقض القرنسية لا تستند إلى أسساس معين ذلك أن كل القوانين التى تتضمن التجريم و العقاب تستهـف حماية المصلحة

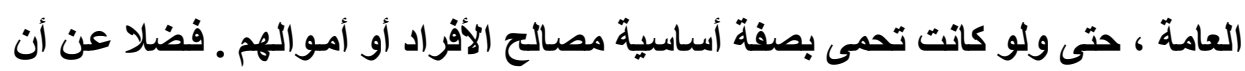

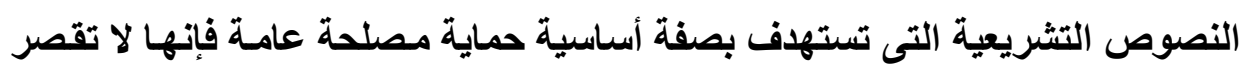

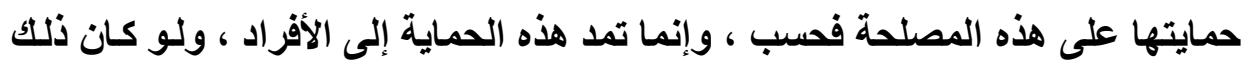

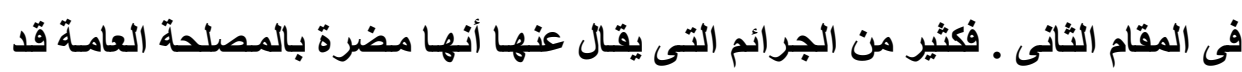

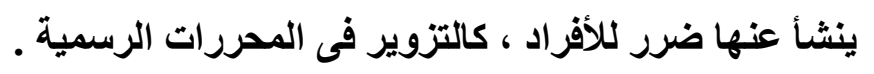

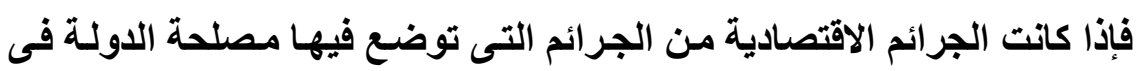

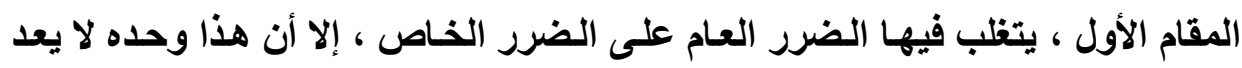

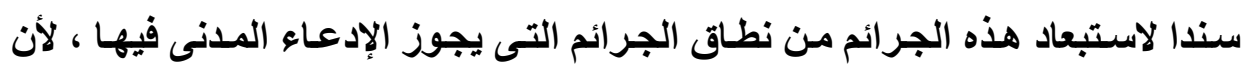


العبرة هى بما إذا كاتت الجريمة قد ألحقت أو لم تلحق ضررا بالمدعى ـ فكثيرا ما تسبب

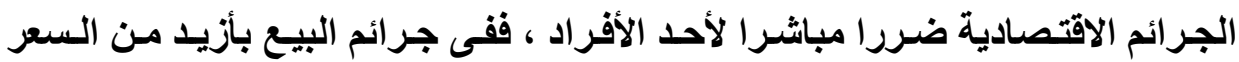

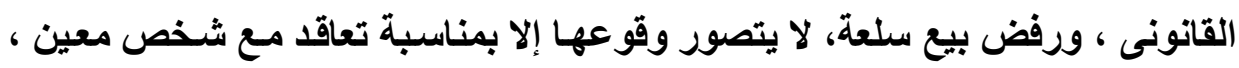
أو رفض التعاقد معه، ومن ثم فبان النصوص التشريعية التى تجرم سلوك البـائع لا تقصر حمايتها على المصلحة العامة فحسب ، بل تمد هذه الحماية إلى الأفراد ، ولو كان

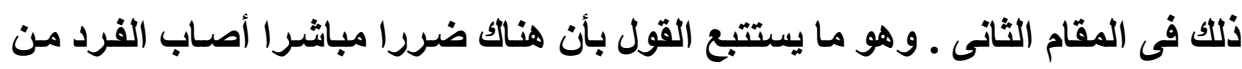

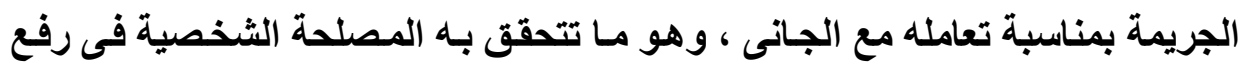

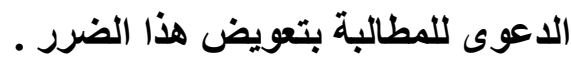

لذلك نجد أن هذه التفرقة لا تصلح سندا لقضاء محكمة النقض الفرنسية ، خاصة وأنها لم تبين حدود جرائم المصلحة العامة ، ويالتالى لم تحدد المعيار الذى على أساسه استبعدت الجرائم الاقتصادية من نطاق الجرائم التى يجوز الإدعاء المدنى عن الضرر

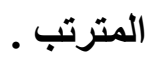

و الحق أن الأمر يرجع لا إلى نوع الجريمة ، أو طبيعة المصلحة محل الحماية

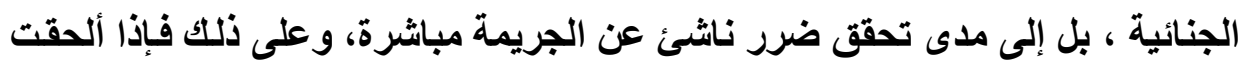

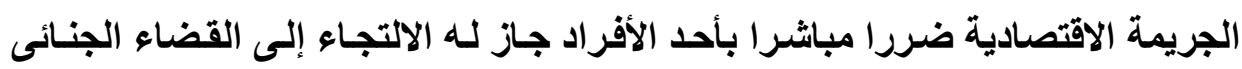

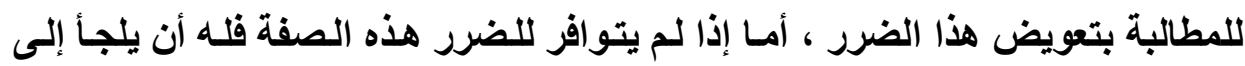

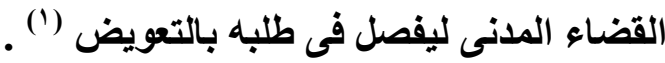

(1) راجع فى تأييد هذه الوجهة من النظر : الاكتور محمود مصطفى : المرجع السابق رقم V؛ اص ص

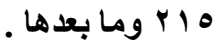


وغنـى عـن البيـان أن الـضرر الناشـسئ عن الجريمـة الاقتصادية، يتميز عن الضرر العام أو الاجتماعى الناشئ عن الجرائم الأخرى المضرة بالمصلحة العامة ، بأنه

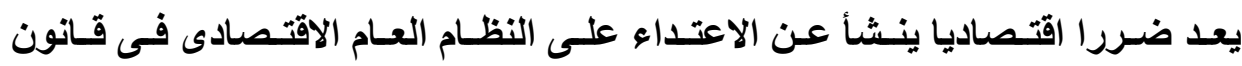

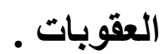

\section{الفرع الثالث \\ همارسة الدعوى البنائية}

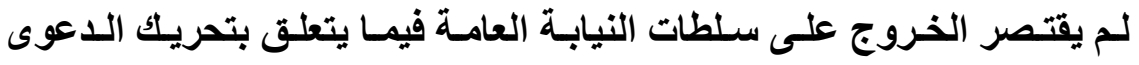
الجنائية فى الجرائم الاقتصادية فحسب ، بل امتد كذلك إلى ممارستها. فدور الإدارة لا ينتهى عند مجرد تقديم الطلب لتحريك الدعوى الجنائية ، بل تملك أيضا التنازل عن طلبها أو التصالح مع المتهم ، فتتضضى الدعوى الجنائية بأيهما (') . هق الإدارة فى التنـازل والتصالح الواقع إن نظام التنازل أو التصالح مـع المتهم المخول للإدارة ، يعد أحد أوجه الخروج عن القانون العام ، لأنـه إذا كانت النيابـة العامـة لا يمكنهـا التـــازل أو التصالح عن الدعوى الجنائية ، فالمجتمع وحده هو صاحب الثأن فى إيقافها أو تعطيل سيرها ، فإنه من الغريب أن يرى هذا الحق وقد منح للإدارة ـ وقد أدخل نظام التنازل والتصالح

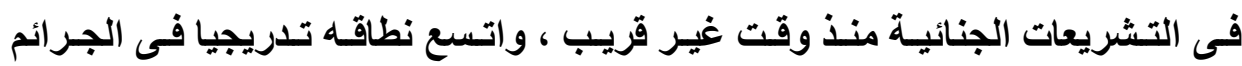
الاقتصادية .

Stefani, levasseur et Bouloc : Op. Cit., No. 125, P. 135. 
وقيل تبريرا لذلك : إنه من الوسائل الأساسية فى قانون العقوبات الاقتصادى

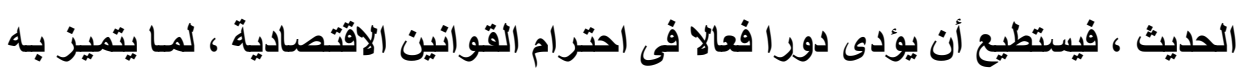

من خصيصة " عينية " (') العنان

\section{نظام الصلح فى القانون الفرنسى :}

أدخلت فرنسا نظام الصلح فى تثريعاتها منذ نهاية القرن الثامن عشر، و أصبح

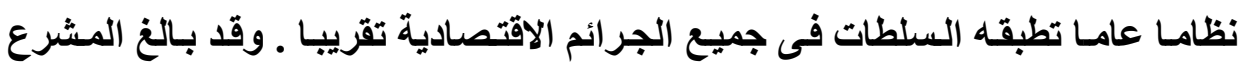
الفرنسى فى الاهتمام بنظام الصلح إلى حد أنه نص عليه كسبب من أسباب انقضاء

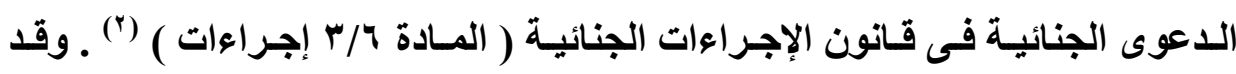

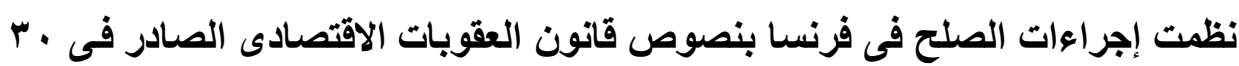

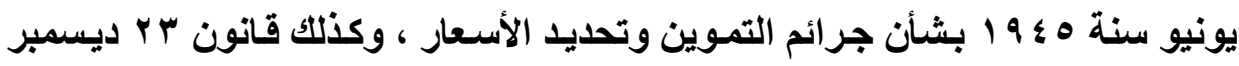

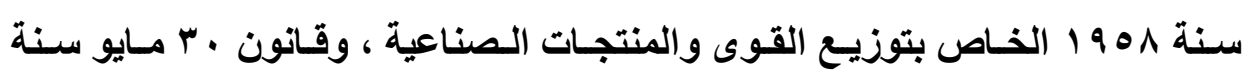

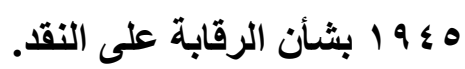

وقد اتجه المشرع الفرنسى إلى التخفيف من خروج نظام الصلح على القواعد

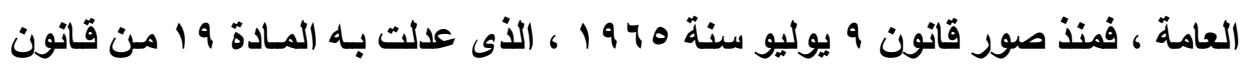

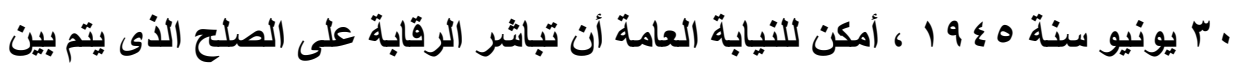

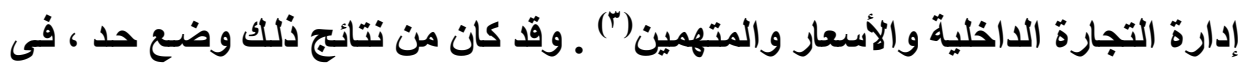

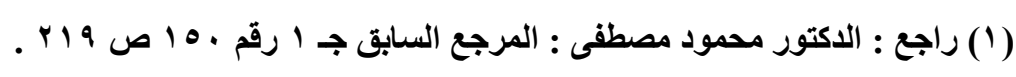

Stefani, levasseur et Bouloc : No. 137, P. 147 ets.

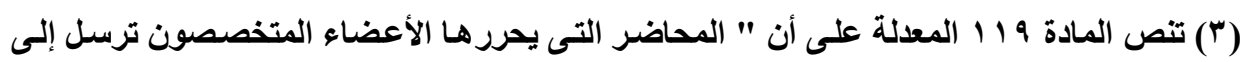

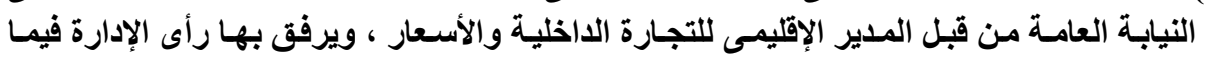
يتطق بالتصالح أو العير فى اللعوى ، فياذا تمت الموافقة على الصلح تعاد الأوراق إلى المدير العير $=$ 
هذا المجال ، للاعتداءات المؤسفة على العدالة ، خاصة فى حالـة كثرة القضايا ، ومن ناحية أخرى تزايدت مسئولية السلطة القضائية بمقدار تزايد سلطاتها ، فقد منح هذا

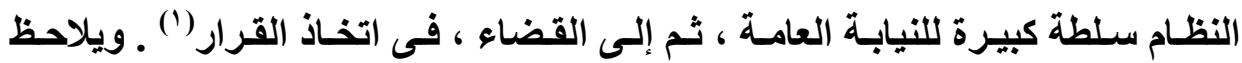

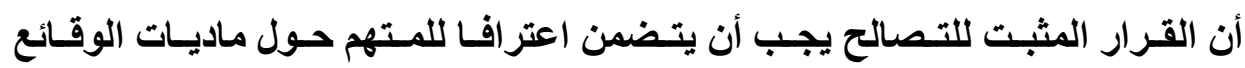

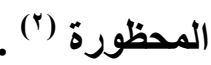

غير أنـا إذا اعترف المـتهم صـراحة أمسام الجهـة الإداريـة المختصة بارتكـاب

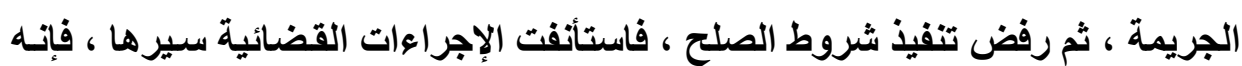
يمكنه العدول عن هذا الاعتراف السابق ، ولا يجوز للجهة القضائية التعويل على هذا

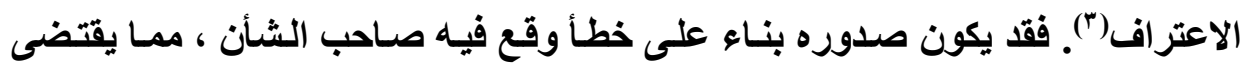

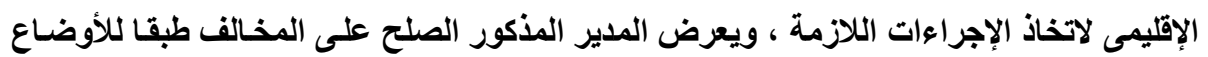

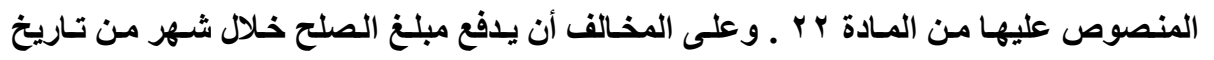

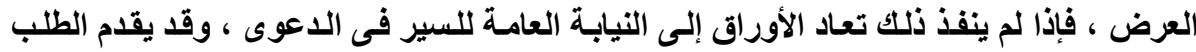

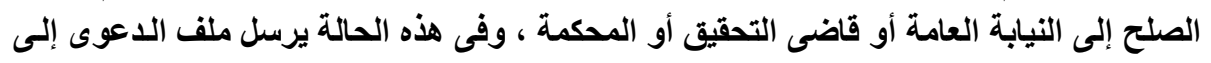

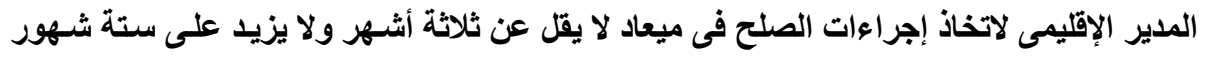

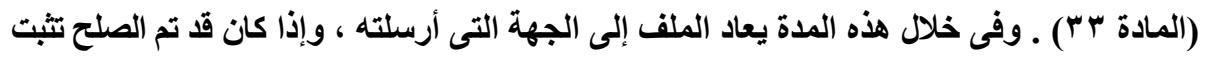

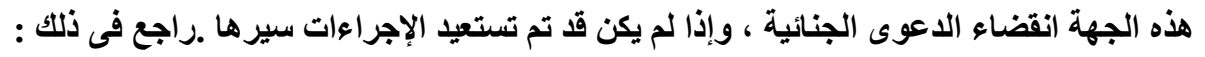
Genry (V.) : Transaction économique et action civile, à la recherche d'une conciliation, Rev. Sc. Crim. 1981, P. 281; costa : art. Précité. P. 112.

Costa : Op. Cit., P. 113.

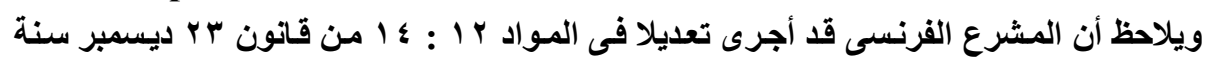

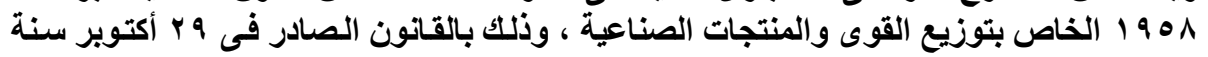

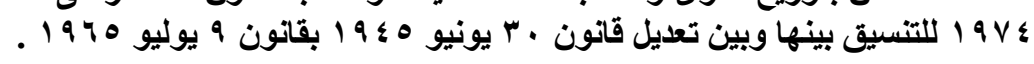

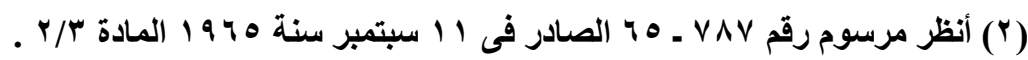
: (r)

Crim. 18 Janv. 1950, Rec. dr. Pén. 1950, P. 146. 
عدم تقييده به تحقيقا للضمانات الفردية ـ ومن ناحية أخرى ، فإن سقوط الصلح يترتب عليه بالضرورة محو أثر الاعتراف الذى كان يتضمنه هذا الصلح (') ـ وتجدر الإشسارة

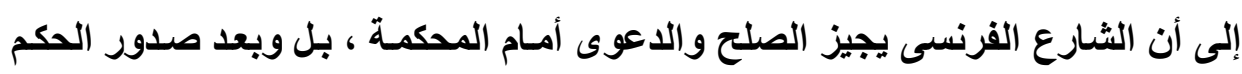
النهائى فحى بعض الحالات(") .

نظام الصلح فى القانون المصرى :

خلافا للشارع الفرنسى ، لم يأخذ الثـارع المصرى فى البدايـة بنظام الصلح فى

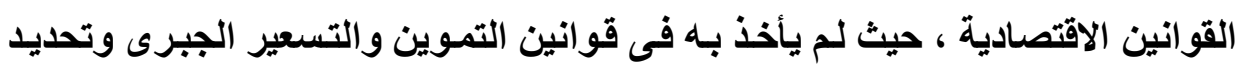
الأرباح ـ غير أنه اتجه فى وقت لاحق إلى الأخذ بـه ، خاصـة فى بعض الحالات التى يتوقف فيها تحريك الدعوى الجنائية على طلب . ومن قبيل ذلك ما أجازه قانون البنك البنك المركزى والجهاز المصرفى والنقد

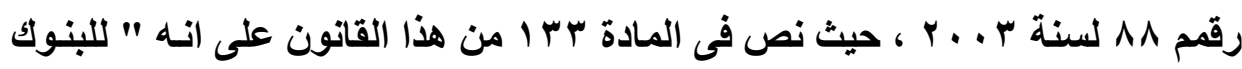

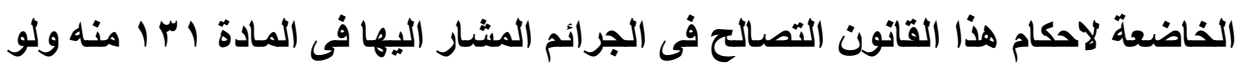
كان قد صدر بشأنها الطلب المنصوص عليه فى هذه المادة ، وذلك فى ايـة حالة تكون

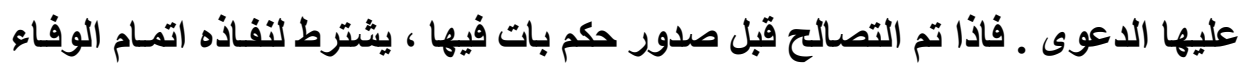
بحقوق البنك وفقا لشروط التصالح ، وفى حالة صيرورة الحكم باتا لا يكون التصالح

( ) (1) راجع فى ذلتك : (1)

Merle et Vitu : Traité Précité, T. 11, No. 892, P. 75 ets., et Dr. Pén. Sp. V. 1, No. 916, P. 727 ets.

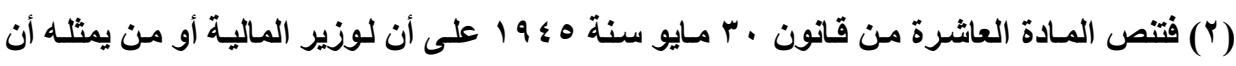

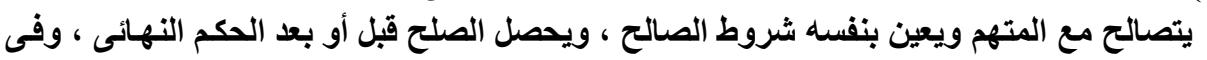

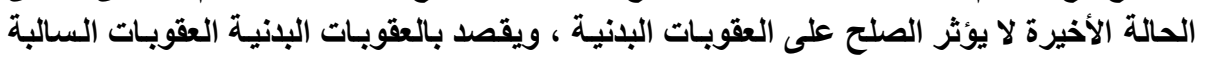

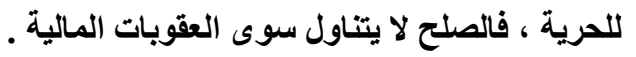


ناقذا الا اذا قام المحكوم عليه بالوفاء المسبق بمستحقات البنك ـ وفى جميع الاحوال يشترط موافقة مجلس ادارة البنك الدائن على التصالح ـ ويحرر عنه محضر يوقعه أطر افه ، ويعرض على محافظ البنك المركزى مؤيدا بالمستتدات للنظر فى اعتماده ، ولا يكون التصالح نافذا الا بهذا الاعتماد وتوثيقه ، ويكون التوثيق بدون رسوم ـ فاذا لم يوافق مجلس ادارة البنك الدائن على التصالح رغم الوفاء بكامل حقوق البنك يعرض الامر بناء على طلب ذى الثأن على مجلس ادارة البنك المركزى لاتخاذ ما يراه مناسبا. ويكون لمحضر الصلح فى هذه الحالة قوة السند التفيذى ويتولى المحافظ اخطار النائب

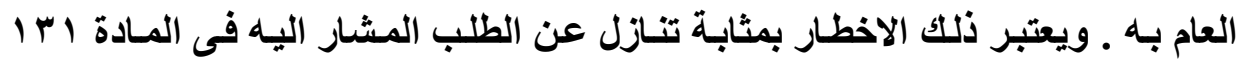
ويترتب عليه انقضاء اللاعوى الجنائية عن الواقعة محل التصالح بجميع أوصـافها. وتأمر النيابة العامة بوقف تنفيذ العقوبات المحكوم بها على المتهمين فى الواقعة اذا تم التصالح قبل صيرورة الحكم باتا. "(')

أما فى الحالات التى لا نص فيها على الصلح ، فيجوز لمن قدم الطلب أن يتــازل عنه بلا مقابل فى أى وقت قبل صدور حكم بات فى الدعوى ، وتنقضى الدعوى الجنائية

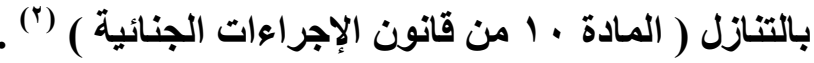

( (1) ويلاحظ انه اذا تم التصالح بعد صيرورة الحكم باتا ، وكان المحكوم عليه محبوسا نفاذا لهذا الحكم،

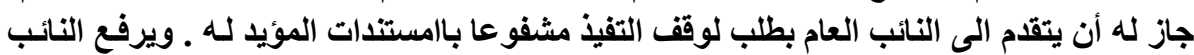

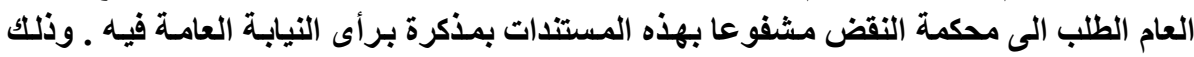

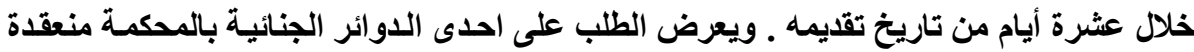

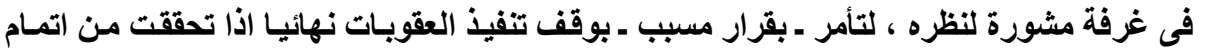

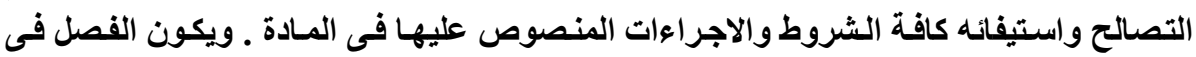

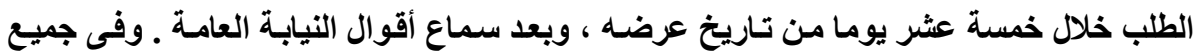

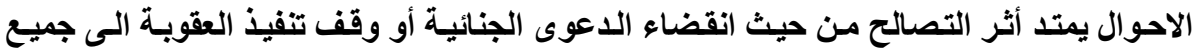

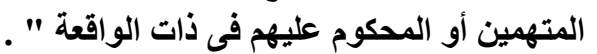

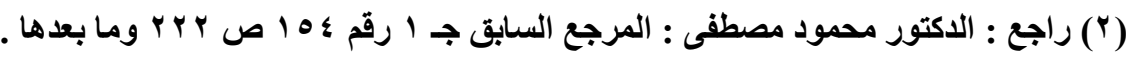




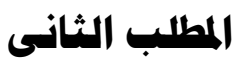

\section{الخروج عن المبادئ الأساسية فى الماكمة}

لوحظ على أثر التطورات التى لحقت النظام العام الاقتصادى فى قانون العقوبات أن اقتضى الأمر مخالفة أحكام الاختصاص المحلى بتخصيص قضاة من ذوى الخبرة والاراية للنظر فى بعض الجرائم الاقتصادية ، خاصة الخطيرة منها .

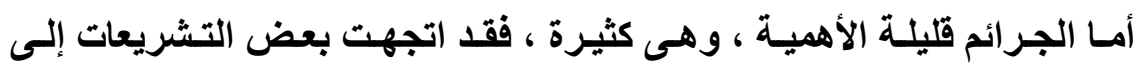

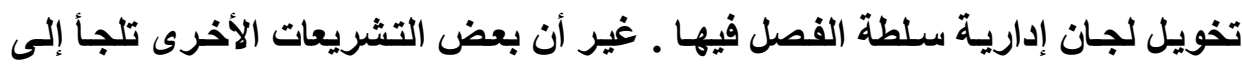

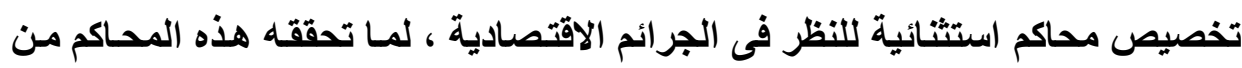

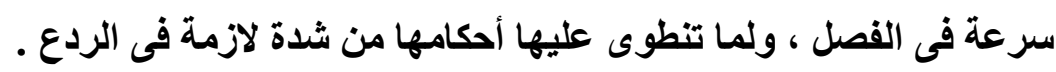
وفيما يلى سنبين أحكام الاختصاص بنظر الجرائم الاقتصادية فى كل من التشريع

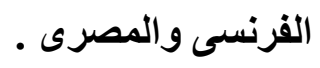

\section{أولا : أحكام الاختصاص فى القانون الفرنسى :}

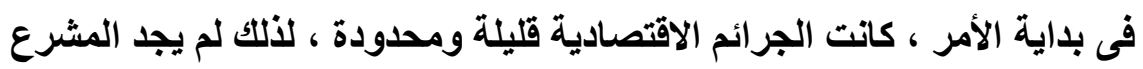
الفرنسى حاجة إلى الخروج عن القواعد العامة فى اختصاص المحاكم ، باستثناء نظام

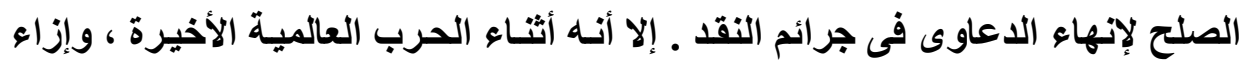

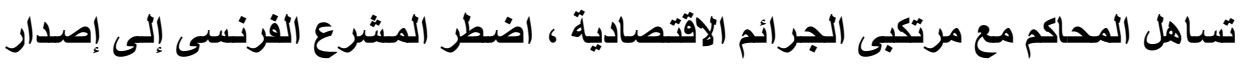

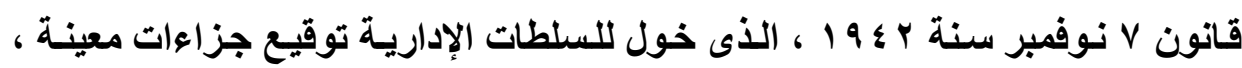

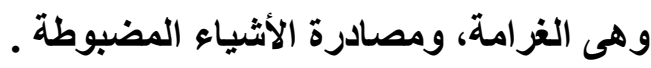


غير أن الإدارة لم يكن لها سلطة توقيع العقوبـات المالية الجسيمة إلا بعد أخذ

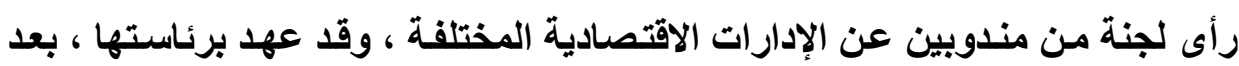
تحرير فرنسا ، إلى أحد القضاة وأدخل فيها ممثلون للمستهلكين والأوساط الصناعية

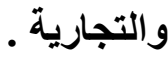

ثم اتجه الثارع الفرنسى إلى النظام الطبيعى ، وهو اختصاص المحساكم العادية،

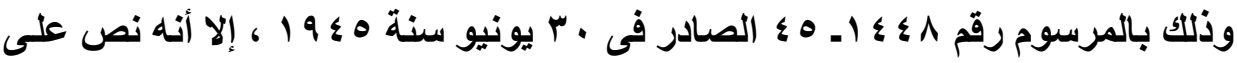

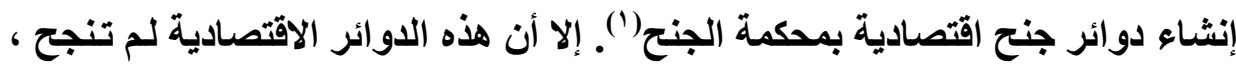
لقلة اهتمام الجمهور بالمساهمة فيها ـ مما أدى إلى إلغاء هذه الاوائر بالقانون الصادر فى 9 يونيو سـنة 9 ؛ 19 ، و وأعيد الاختصاص فى الجنح الاقتصادية لمحساكم الجنح العادية(") ـ ويعد إلغاء القضاء الاستثنائى خطوة هامة ، خاصة فى مجال يلاحظ فيه دور الدولة بدرجة كافية .

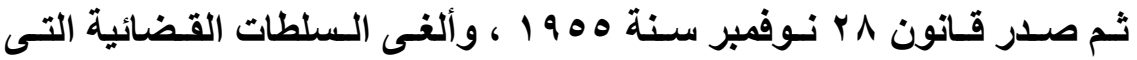

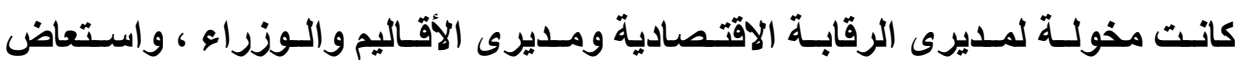

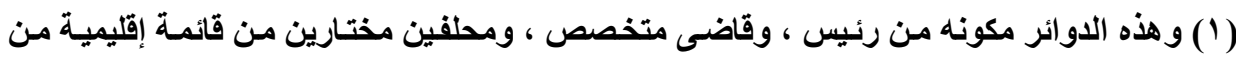

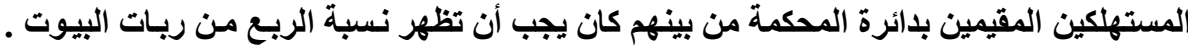

$$
\text { راجع : (الستين }
$$

Hugueney ( P. ) : les chambres correctionnelles économques, Rev. int. dr. Pén. 1947. P. 27 ets.

Levasseur : Rapport Précité H. Capitant T. XXII, No. 12 ets., Merle et Vitu : Dr. Pén. Sp., OP. Cit., No. 917, P. 728. 


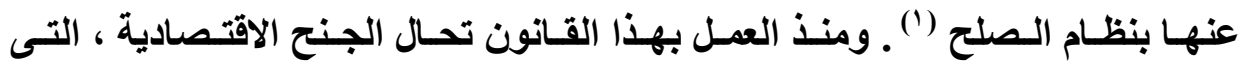

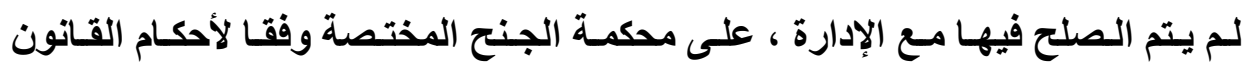

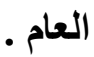

والو اقع أن القاضى الجنائى لا يملك فى مجال تقدير النظام العام الاقتصادى كامل السلطات التى له بالنسبة لجرائم القانون العام ـ ذلك أن القاضى الجنائى فى الجرائم

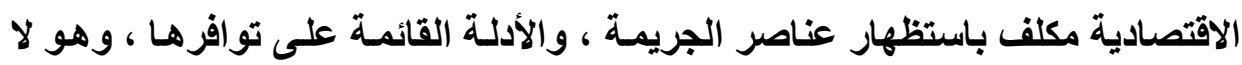

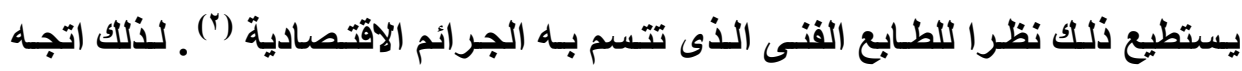

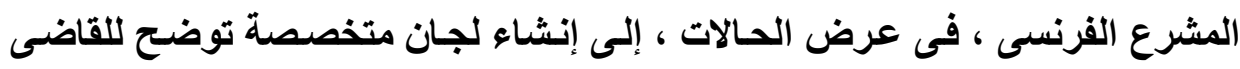

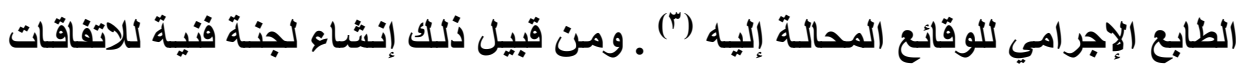

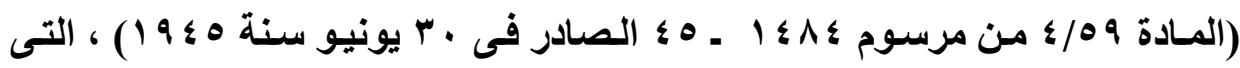
تبدى رأيها حول الاتفاقات ، وتثثل هذه اللجنة من فنين متخصصين ، وغالبا مـا ينضم

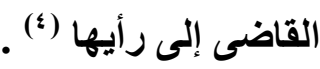

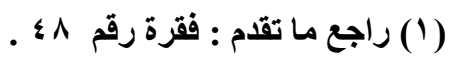

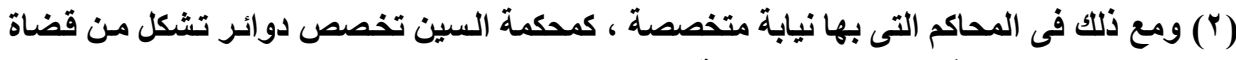
متخصصين للفصل فى الجرائم الاقتصادية .

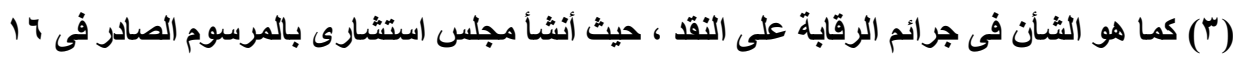

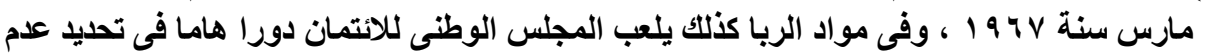
مشروعية السعر الممارس به مانه

Savatier : chron, Précité, P. 41. 
الواقع أن استعانة القاضى الجنائى برأى المتخصصين فى الاقتصاد أمر طبيعى،

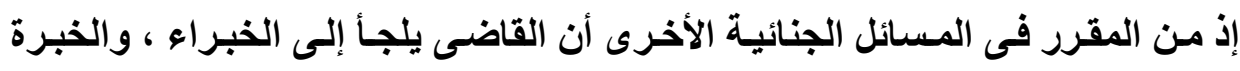

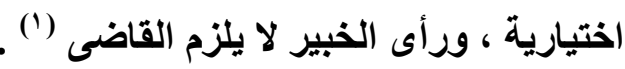

غير أن المثكلة فى الجرائم الاقتصادية ليست فى لجوء القاضى إلى لجان فيما

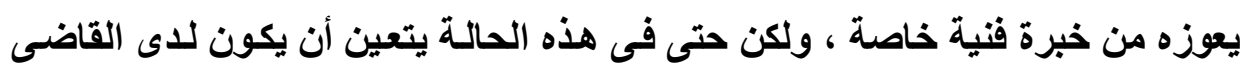

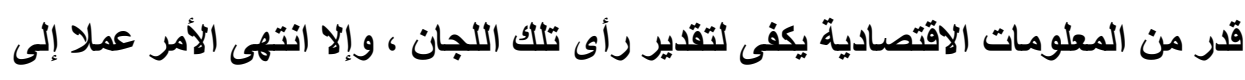

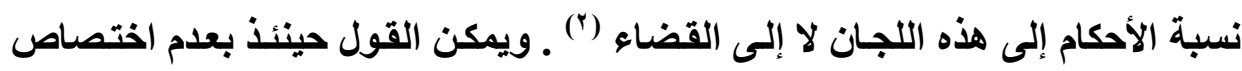

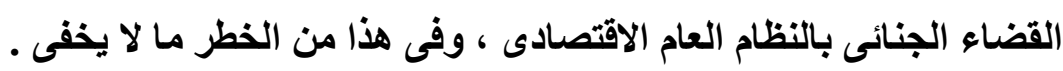
لذلك اتجه المشرع الفرنسى أخيرا إلى تخصيص محكمة جنح أو أكثر فى دائرة

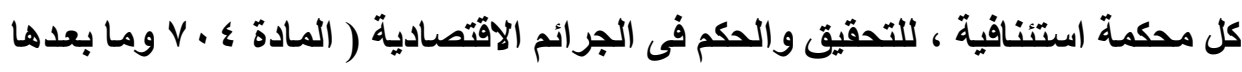

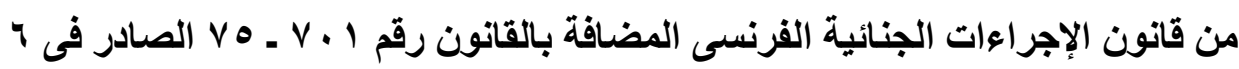

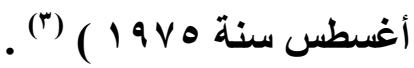

(1) راجع فى الموضوع : الاكتورة آمال عثمان : الخبرة فى المسائل الجنائية ، رسالة دكتوراه القاهرة

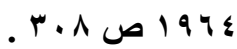

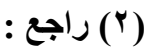

Leauté : Rapport Précité in H.capitant, T.XIII, 1963, P. 632.

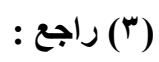

Couvrat ( P. ) : Les méandres de la Procédure Pénale, D. 1976, chron, P. 43,; Merle et Vitu : Dr. Pén. Sp., Op. Cit., No. 917, P. 728.

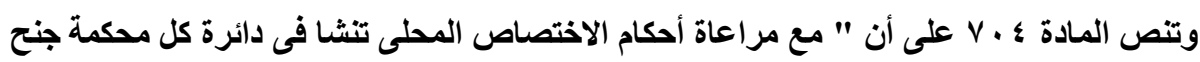

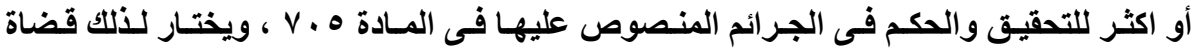
متخصصون فى المواد الاقتصادية والمالية بعد اخذ رأى الجمعية العمومية للمحكمة المذكورة " . 
غير أنه يلاحظ أن اختصاص القضاء المتخصص ليس إلزاميـا ، وإنمـا إذا رأت النيابة العامة أن الجريمة مما ياخل فى عداد الجرائم الاقتصادية المنصوص عليها فى إنى المـادة ه • V إجراعات فرنسى (') ، فلها أن تطلب من رئسيس غرفة الاتهام أن يحيل اللدعوى إلى قاضسى التحقيق المتخصص ، ولرئيس غرفة الاتهام أن يفصل فى هذا الطلب بأمر مسبب خلال ثلاثة أيام من تلقى الطلب ( المسادة ؟ . V إجراءات فرنسى ) . ويجوز تقديم هذا الطلب من قاضسى التحقيق ( المسادة ؟ ، I/ إجراعات فرنسى ) .

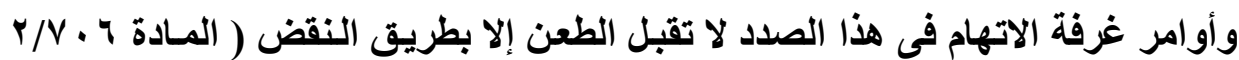

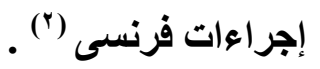

\section{أصكام الاختصاص فى القانون المصرى :}

خلافا للوضع المقرر فى القانون الفرنسى ، لم يجد الثارع المصرى حاجة إلى الخروج عن القواعد العامة فى اختصاص المحاكم ، لألك ظل اختصاص محسكم القانون العام ممتدا إلى كثير من الجرائم الاقتصادية ـ هذا باستثناء بعض الجرائم الاقتصادية التـى نـصت الأوامـر العسكرية أو قـرارات رئسيس الجمهوريـة بإحالتهـا إلـى المحسكم العسكرية أو محاكم أمن الدولة .

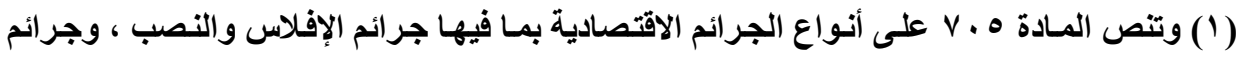

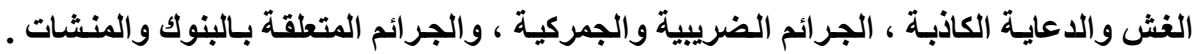

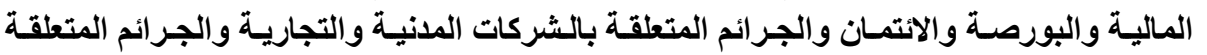

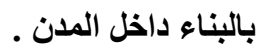
: (r) (r) (ب)

Stefani, levasseur, et Bouloc: Op. Cit., No. 368-b, P. 428 ets. ; Merle et Vitu : OP. Cit., No. 917, P. 728 ets. 
غير أنه يلاحظ أنه قبل اب يناير سنة و O V كانت المحاكم العادية تنظر جميع

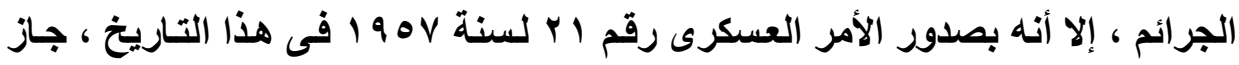
للنيابة العامة أن تحيل إلى المحاكم العسكرية الجرائم المنصوص عليها فى المرسومين

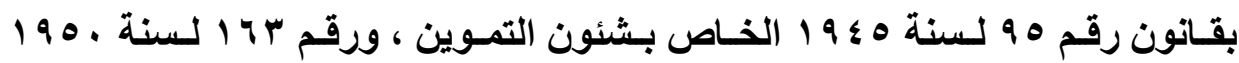
الخـاص بالتسعير الجبرى وتحديد الأربـاح والقرارات المنفذة لهمـا ، وكذلك الجرائم

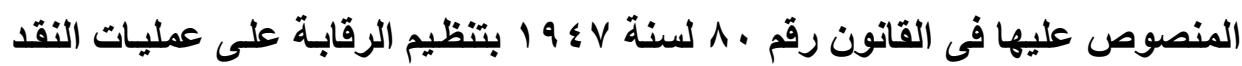
والقوانين المعدلـة لـه والقرارات المنفذذة لـه ، والجرائم المنصوص عليهـا في الأمر

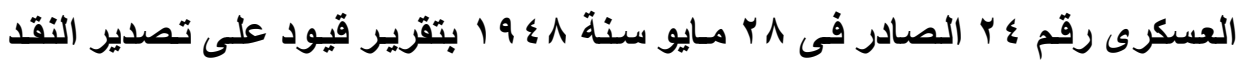
والمصوغات وما إليها ( المادة الأولى من الأمر العسكرى ) . وقد جرى قضاء محكمة النقض على أن اختصاص المحاكم العسكرية بالفصل فى بعض القضايا لم يسلب المحاكم العادية حقها بالفصل فى هذه القضايا ، فإذا مـا رأت النيابـة تقديم متهم إلى محساكم العاديـة ليحـاكم أمامهـا عن جريمـة ممـا خولت المحساكم

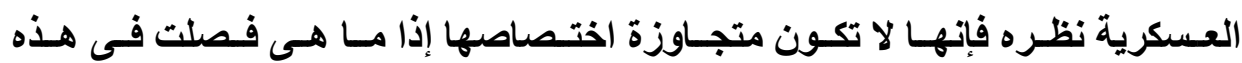
الاعوى (') ـ ولا يجوز للمحكمة بالتالى أن تتخلى من تلقاء نفسها عن اختصاصها (†) .

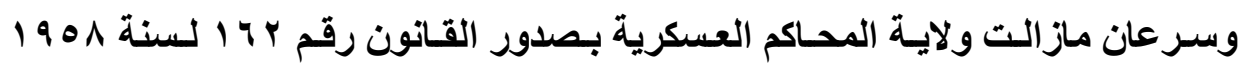
بثأن حالة الطوارئ ، ونص فيه على أن " تفصل محاكم أمن الدولـة الجزئية والعليا فى الجرائم التى تقع بالمخالفة لأحكام الأوامر التى يصدرها رئيس الجمهوريـة أو من يقوم مقامـه " ( المـادة السابعة ) ـ وينـاء على ذلك أصدر رئسيس الجمهوريـة القرار

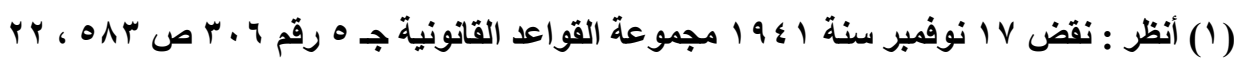

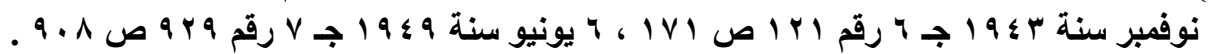

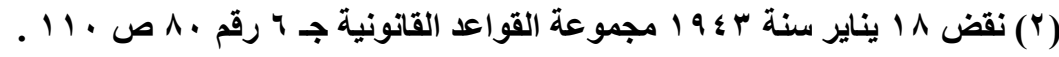


رقم أ لسنة ^ه 19 وأجاز للنيابة العامة أن تحيل إلى محاكم أمن الدولة الجزئية ذات الجـرائم التـى كـان يجيز لهـا إحالتهـا إلى المحساكم العسكرية ، وهـى جـرائم التمسوين والتسعير الجبرى وجرائم النقد ، وأضـاف إليها جرائم التهريب المنصوص عليها فى

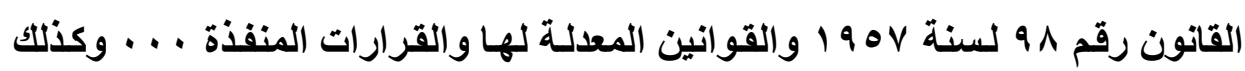

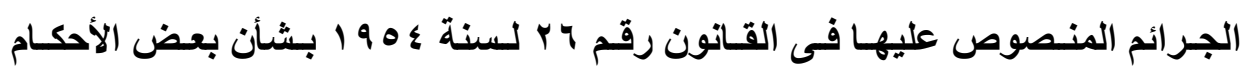
الخاصـة بشركات المسـاهمة وغيرهـا مـن الشركات والقواتين المعدلـة لـه والقـرارات المنفذة لله ، والجرائم المنصوص عليها فى القانون رقم به 19 لسنة و 190 بإصدار قانون البنوك والائتمان والقرارات المنفذة له .

ولمـا كـان هذا النوع من المحساكم موقوتـا بمرحلة خاصـة هى حالـة الطوارئ ،

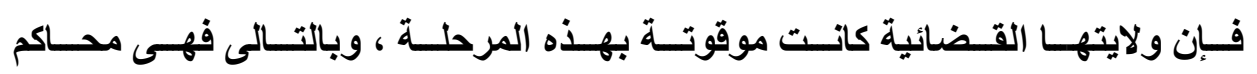
(1) (1) (1) وقد زالت ولاية هذه المحاكم بإلغاء حالة الطوارئ ، غير أنه سرعان مـا أعلنت

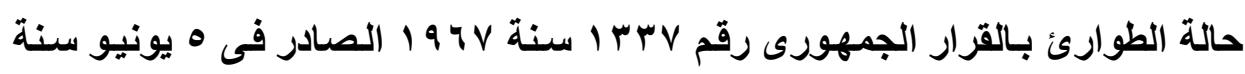

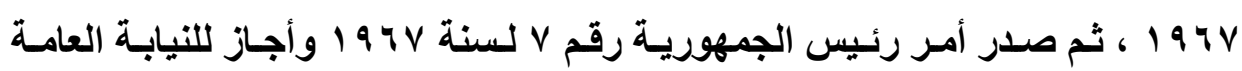
إحالة جرائم التموين والتسعير الجبرى إلى محاكم أمن الدولة ( المـادة الأولى ) ـ وقد أغفل الأمر المذكور جرائم النقد والتهريب والبنوك والشركات فقد ظل النظر فيها من اختصاص المحاكم العادية ، ويلاحظ أن محاكم أمن الدولة " طوارئ " لـم تكن تثفرد بالاختصاص فى الجرائم التى يجوز إحالتها إليها ، فالأوامر الجمهورية الصادرة تنفيذا 
لقانون الطوارئ لم تسلب المحاكم العادية سلطتها فى نظر الجرائم الاقتصادية ، فهى تجيز ولا توجب إحالة الجرائم التى تتضمنها إلى محاكم أمن الدولة (').

والواقع من الأمر أن الجرائم الاقتصادية ليست من الجرائم المؤقتة التى ترتبط بحالة أو فترة معينة ، بل هى جرائم مرتبطة تمام الارتباط بالنظام العام الاقتصادى لذلك كان من المتنـاقض جعل الاختصاص فى نظر تلك الجرائم لمحاكم استثنائية مرتبطة بفترة مؤقتة .

وقد زالت ولايـة محاكم أمن الدولة " طوارئ " بانتهاء حالـة الطوارئ بقرار

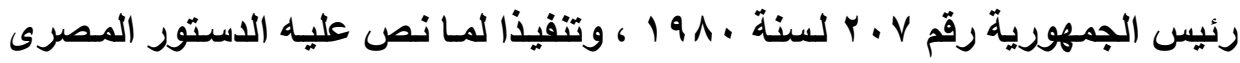
فى الفصل الخـاص بالسلطة القضائية فى المـادة IVI منـه على أن " ينظم القـانون ترتيب محاكم أمن الدولة ، ويبين اختصاصاتها والثروط الواجب توافرها فيمن يتولون القضاء فيها " ، صدر القـانون رقم هـ ـ 1 لسنة ـ 19 1 بإنشاء محسكم أمسن الدولـة الدائمة باعتبار ها جزء من النظام القضائى بنص الاستور ، وليست مرتبطة بحالة أو فترة معينة ، وطبقا لهذا القانون تنشأ فى دائرة كل محكمة من محاكم الاستئناف محكمة أمن الدولة عليا أو أكثر ، كما تنشأ فى كل محكمة جزئية محكمة أمن الاولـة جزئية أو

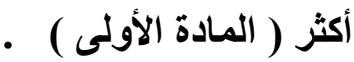
وقد خص المشرع فى القانون رقم ه ـ 1 لسنة ـ 19 1 سـالف الذكر محساكم أمن الدولة ، من بين ما اختصت به ، بنظر بعض الجرائم الاقتصادية وهى جرائم التموين المعاقب عليهـا بالمرسـوم بقـانون رقم ه9 لسنـة هـ 9 1 ، وجرائم التسعير الجبرى المعاقب عليها بالمرسوم بقانون رقم به 1 لسنة ـ 190 أو القرارات المنفـة لهـا. ( ) راجع : الاكتور محمود مصطفى : المرجع السابق رقم ع 11 ص roV . . 
وينعقد الاختصاص لمحاكم أمن الدولة العليا إذا كاتت الجريمة معاقب عليها بعقوبة أثد من الحبس ( ب/ 1 ) ، ولمحكمة أمن الدولة الجزئية إذا كاتت الجريمة من الجرائم غير المعاقب عليها بأثد من الحبس ( ب/ ( ) ) .

ويلاحظ أن المشرع فى القـانون رقم ه ـ 1 لسنة . 19 1 ، قد سـلب المحساكم العادية حقها فى النظر فى الجرائم التى خول لمحاكم أمن الدولـة العليا نظرهـا ، حيث نص على أن هذه المحاكم تختص بـالجرائم السابقة دون غيرهـا ( المسادة ب ) ـ وهذا على خلاف مـا كـان عليه الحـال بالنسبة لمحاكم أمن الدولـة التى أنشأها قانون حالـة الطوارئ ، حيث لم يكن قانون الطوارئ يسلب المحاكم العادية سلطتها فى نظر الجرائم التى خول محاكم أمن الدولة نظرها ـ ومن ناحية أخرى يلاحظ أن القـانون رقم هـ .

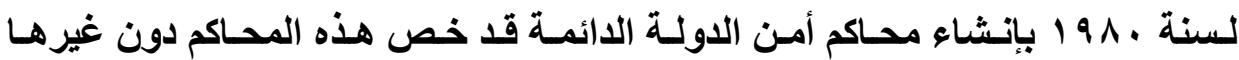

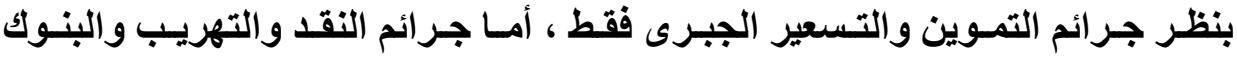
والشركات فقد أغفل ذكرهـا ـ ومقتضى ذلك أن المحساكم العادية تستمر فى نظر هذه

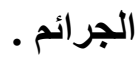
والواقع من الأمر أنه ولئن كاتت محكمة أمن الدولة هى مجرد دائرة من دوائر محكمة الاسـتئناف أو المحكمة الجزئيـة ـ ـ إلا أن تخويلهـا الاختصاص بنظر بعض الجرائم الاقتصادية ليس عودا إلى النظام الطبيعى ، وهو اختصاص المحاكم العادية. . فسلب ولاية هذه المحاكم الأخيرة من نظر بعض الجرائم الاقتصادية وتخويلـه لمحاكم أمن الدولة ، رغم تميزها بتشكيل خاص يبرر هذا المسلك ، ليس فحسب خروجا عن القاعدة العامة التى تقرر اختصاص القضاء العادى بنظر الجرائم الاقتصادية ، بـل هو أيضـا أمسر لا يتفق والطـابع الفنى الذى تتسم بـه الجرائم الاقتصادية ، التى توجب تخصيص قضاة من ذوى الخبرة والاراية بما تثيره هذه الجرائم . 
وبالغاء محاكم امن الدولة العليا ، بالقانون رقم ه9 لسنة ب . . ب أصبح نظر

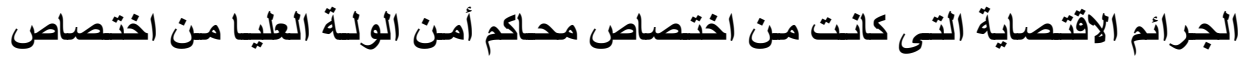
المحاكم العادية بالاضافة الى ما كانت تختص بنظره .

واخيرأ اتجه المشرع المصرى الى انثاء المحاكم الاقتصاية بالقانون رقم · Yr

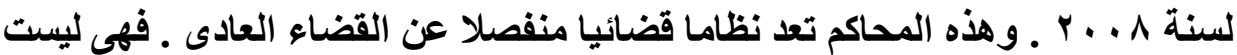

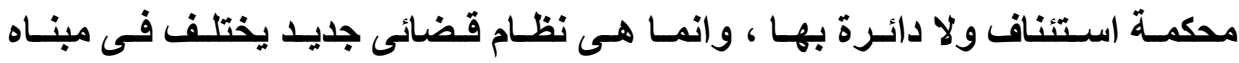
ومضمونه عن النظام القضائى العادى ـ وتختص الدوائر الابتائية بالمحاكم الاقتصادية

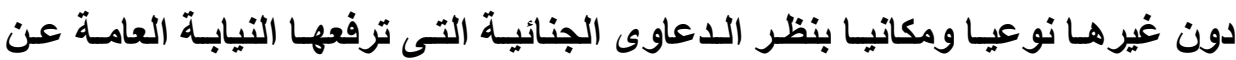
الجرائم المنصوص عنها فى القوانين التى حددتها المـادة الرابعة من قانون انشاء

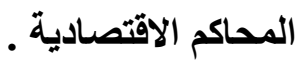

ويلاحظ ان الجرائم الاقتصادية التى اسندت الى المحاكم الاقتصاية الاختصاص

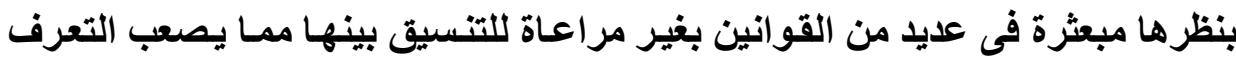
على مفهومها ، او الاهتداء الى تفسير لبعض احكامها ، ممـا يلزم تقنين احكام تلكت فئك

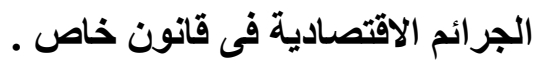

والواقع إن انثاء المحاكم الاقتصادية وإن كان أمراً يتفق والطابع الفنى الذى تتسم به الجرائم الاقتصادية ، التى توجب تخصيص قضاة من ذوى الخبرة والاراية بمـا

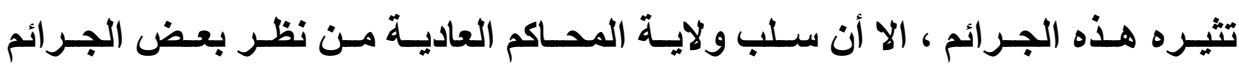
الاقتصادية وتخويله للمحاكم الاقتصادية ، التى تعد نظامـا قضائيا منفصلا عن القضاء

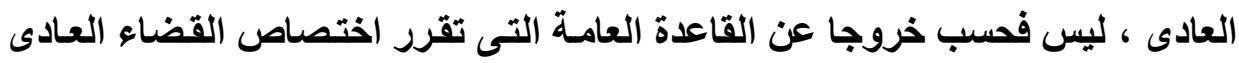


بنظر بعض الجرائم الاقتصادية ، وانمـا خروجـا عمـا يقتضيه مبـدأ النظـام القضائى الواحد.

لذلك نرى ان يكون الاختصاص بنظر هذه الجرائم للدوائر متخصصة، كمـا هو

الثأن فى القانون الفرنسى ، بأن تخصص محكمة جنح أو أكثر فى دائرة كل محكمة استئنافية ، للتحقيق والحكم فى الجرائم الاقتصادية .

وغنى عن البيان ان تخصيص دوائر لنظر الجرائم الاقتصادية لا يسبغ عليها

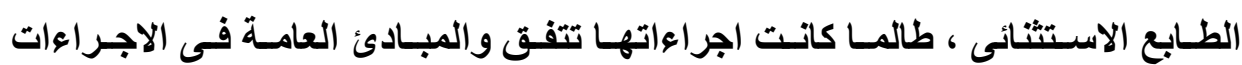

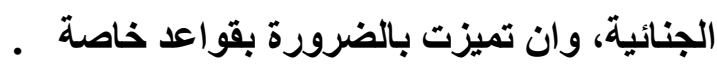

ونـرى انـهـ مـن الأوفق أن يكون الاختصاص بنظر الجرائم الاقتصادية لمحسكم متخصصة فى الشئون الاقتصادية ، تشكل مـن قضاة متخصصين ، وتعد جزء مـن القضاء الجنائى العادى ، واجراءاتها تتفق والمبادئ العامـة فى الاجراعات الجنائية ، وان تميزت بالضرورة بقواعد خاصة .

\section{الإطاب الثالث}

\section{الخروج عن المبادئ الأساسية فى الجزاء}

حظيــت المـشاكل التـى تثيرهـا الجـزاءات فـى قـانون العقوبـات الاقتـصادى باهتمـام بـالغ فـى المحافـل الدوليـة والوطنيـة (') ـ و إذا كـان الخـروج عـن المبـادئ

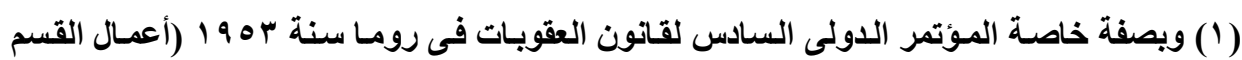
الثالث ) ـ ولا سيما التقرير المقدم من الأستاذ ـ Vouin ـ عن فرنسا ـ ـ راجع :

$=$ 
الأسـاسـية فـى قـانون العقوبـات التقليـدى قــ ظهـر فـى نـواح متعـددة مسن أحكـام

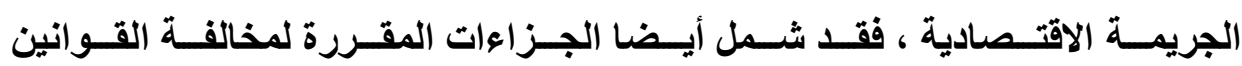
الاقتصادية.

وقد كان لألك تأثير من ناحتين : الأولى قسوة الجزاء ، والأخرى : تعديل وظيفة العقوبة ، وفى حقيقة الأمر أن كل منهما يكمل الآخر .

\section{الفرع الأول}

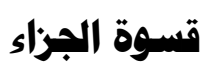

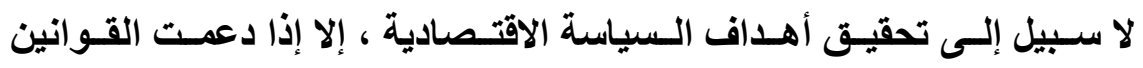

$$
\text { الاقتصادية بالجزاء ، وأشد هذه الجزاءات هى العقوبات (') . }
$$

والواقع من الأمر أن قسوة الجزاء لا ينتج فحسب من تشديد معدل الجزاءات ،

بل بالأثر المانع للجزاءات التهدياية ـ ومن خلال ذلك تتحقق صفة الإكراه التى يتسم بها

Rev. int. dr. Pén. 1953, P. 423 ets. ; Ancel ( M. ) : les sanctions en matiére de droit Pénal économique, in Rapports généraux au 5 eme congrés int. de dr. comp., Bruxelles 1960, P. 851 ets.; Hemard ( J. ) : le rapport francais au méme congrés ; in Etudes de dr. contemporain T.XXII, 1963 P. 541 ets.

(1) راجع فى أنواع العقوبات الجرائم الاقتصادية وأهميتها : الدكتور محمود مصطفى : المرجع السابق

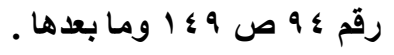


النظـام العـام الاقتصادى (") . والتخفيف مـن الـصفة الـصناعية لكثير مـن النصوص (الجنائية (ن)

وقــ أدرك المـشرع المعاصـر أن مـن حسن السياسة ، إلا يلجـأ إلـى العقوبـات الثديدة ، إذ أن ذلك يضر بفعاليتها ، وأن المبالغة فى قسوة الجزاء ينتج من الإجراءات غير المباشرة والتى تكفل فاعلية الجزاء ـ وفيما يلى أهم تلكك الإجراءات : أولا : التضييق هن نطاق وسائل التخفيف :

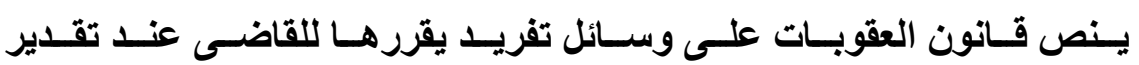
العقوبـة ، غيـر أن الاتجـاه فـى تقـدير العقوبـة عـن الجريمــة الاقتــصادية يميـل إلـى تضييق نطساق تلك الوسـائل ، بحرمسان الجـانى مسن بعض وسـائل التخفيف أو وقف

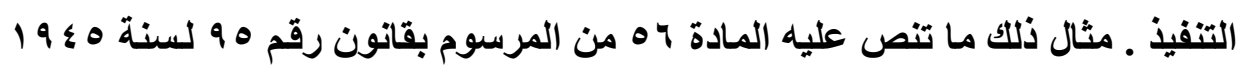
بثئون التموين على أنه : " لا يجوز الحكم بوقف تنفيذ عقوبة الحبس والغرامة " (").

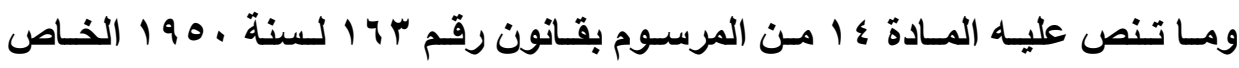

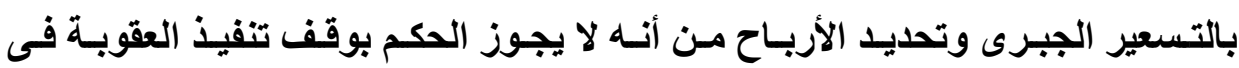

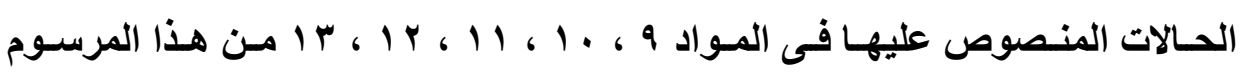

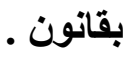


وكذلك نص الفقرة الثانية من المادة ؛ 1 من قانون تنظيم التعامل بالنقد الأجنبى

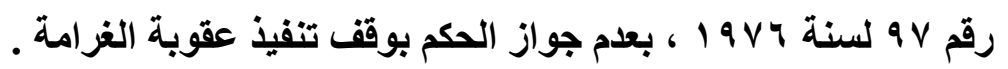

ويبين مـن هذه النصوص وغيرهـا أن المشرع المصرى يجرى على سياسـة

واحدة ، هى حرمان المحكوم عليه فى الجرائم الاقتصادية من وقف التنفيذ بوصفه ميزة يجوز أن يفيد منها المحكوم عليه فى جرائم القانون العام(") ـويلاحظ ان قانون المحاكم الاقتصادية لم يرد به نص يحظر تطبيق وقف تنفيذ العقوبة فى الجرائم الاقتصادية التى

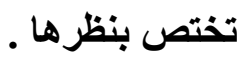

وقد كـان المشرع الفرنسى ، فى أثنـاء الحرب العالميـة الأخيرة ، يجرى على

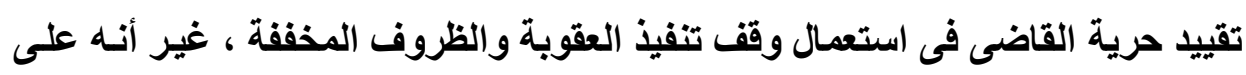
أثر انتهاء الحرب ألغيت هذه القيود (؟) .

ثانيا : عدم تطبيق قاعدة رجعية القوانين الأصلح للمتهم :

يسود الفقه والقضاء المقارن اتجاه نحو استثناء القوانين الاقتصادية من تطبيق قاعدة رجعيـة القوانين الجنائية الأصلح للمتهم (") ـ والعلة فى ذلك أن تطبيق أحكام

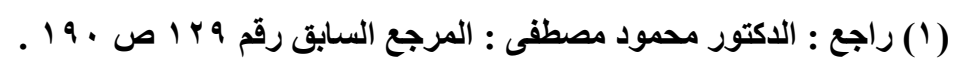

Merle et Vitu : dr. Pén. Sp. Op. Cit., No. 742, P. 596.

$$
\text { : (r) (r) }
$$

Ibid : No. 745, P. 597; Bosly et spreutels : OP. Cit., No. 29, P. 43. ; Bouzat : traité Précité, T. 11. No. 1681, note 2, P. 1284.

مجلتّ البحوث القانونيتّ والإقتصاديت 
القانون بأثر مباشر متى كان أصلح للمتهم يشكل خطرا على السياسة الاقتصادية بالنظر لسرعة تطور القانون الاقتصادية .

وقد آثار تطبيق القوانين الاقتصادية خلافا فى الفقه و القضاء الفرنسيين ، ومدى سريان القوانين الأصلح للمتهم بأثر رجعى ، وخاصـة قرارات تحديد الأسعار التى لـى

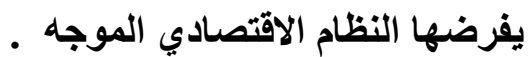
وفى شـأن هذه القرارات ذهب القضاء الفرنسي إلى استبعاد تطبيق القانون

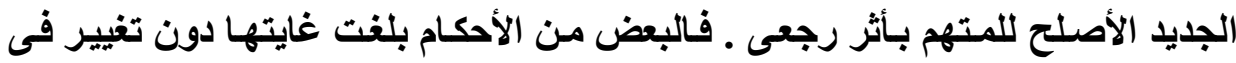
المبادئ، بأن تقرر مثلا تجريم آخر بدلا من التجريم الملفى ـ وميز البعض الآخر بين

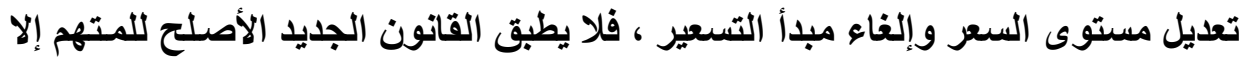
فى الحالة الثانية دون الأولى ـ ولكن منذ الحرب العالمية الثانية ، اتجهت غالبية الأحكام القضائية إلى العدول عن التفرقة تبعا لطيعة التغيير الذى أجراه المشرع ، فسواء

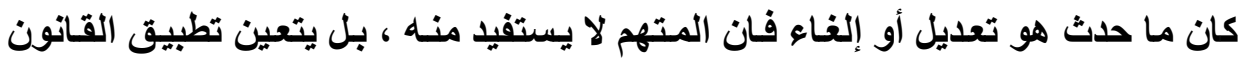

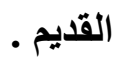

وقد اختلف الفقه الفرنسي فى حل هذه المشكلة فذهب البعض من أنصار تطبيق

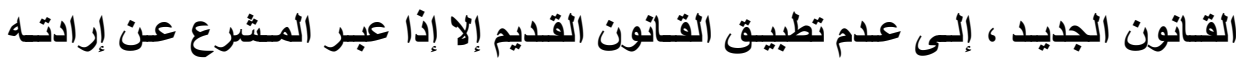

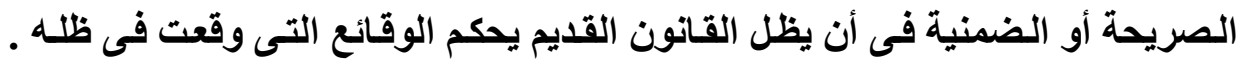
ويناء على ذلك يتعين البحث فى كل حالة عن الغاية التى استهافها المشرع . بينما ذهب البعض الآخر إلى وجوب الأخذ بالتفرقة ، التى أقرها القضاء من قبل التى تعتمد على طبيعة التغيير الذى أجراه المشرع ، ما إذا كان مجرد تعديل فى الأسعار المفروضـة أو على العكس إلغاء مبدأ التسعير ذاتها ، أو التفرقة بين الطابع العقابى التهي 
وغير العقابى للنصوص الصادرة فى المجال الاقتصادي ، أو التفرقة بين نصوص الغاية - DISPOSITIONS BUT B. وهى التى تعبر عن تعديل فى السياسة الاقتصادية بتحقيق هدف مختلف عما استهدفه القانون القديم ، ونصوص الوسيلة

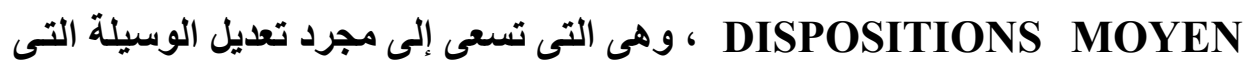
تكفل تحقيق هذه السياسة الاقتصادية . ولم يصادف أيا من هذه المعايير قبولا لاى غالبية الفقه الفرنسي ، استتادا إلى

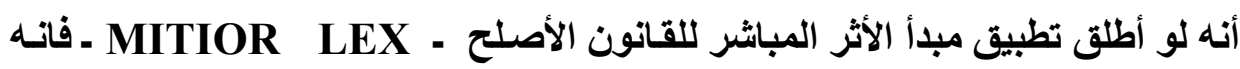
سيؤدى إلى تجريد التظيم الاقتصادي من كل قيمته التهديدية ـ فضلا عن أن هذا الوضع سيؤدى إلى استفادة المتهم من صدور القانون الجديد بغير مبرر . لذلك حرص المشرع الفرنسى على وضع نص خاص لهذه المشكلة فى المسادة

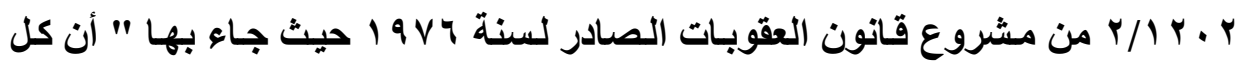
جريمة وقعت مخالفة لنص قانوني أو لانحي يحدد تطبيقه فى فترة محددة أو بطبيعته ، فإنها تظل محكومة بالقانون الذى كان سـارى المفعول وقت وقوعها ، ويستمر تتفيذ العقوبات المحكوم بها" ـ والمراد بعبارة " يحدد تطبيقه فى فترة محددة أو بطبيعته "

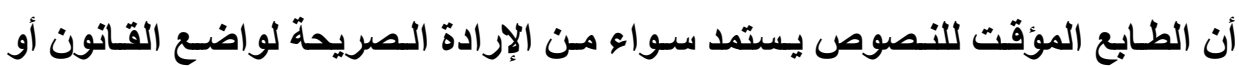

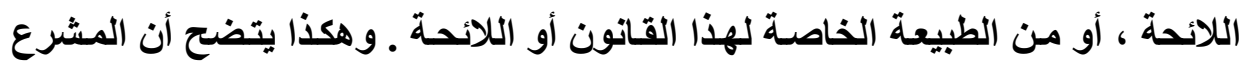

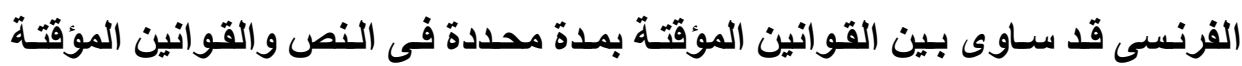

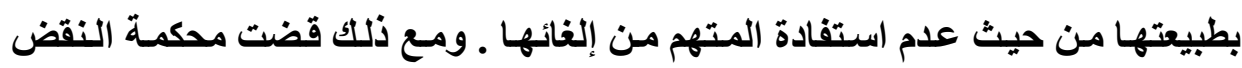

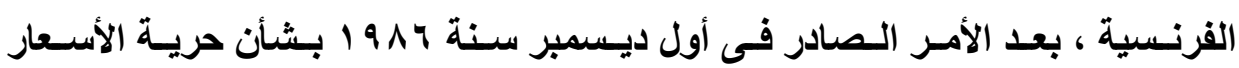

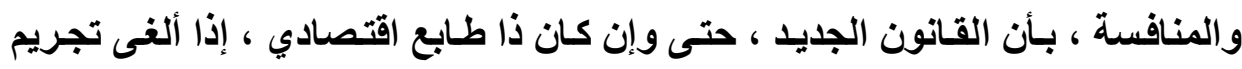


الفعل ، فاته يطبق على الوقائع المرتكبة قبل العمل به و التى لم يفصل فيها بحكم نهائى، ما لم يوجد نص صريح على خلاف ذلك . غير أن قانون العقوبات الفرنسى الجديد الساري سنة ؛ 99 اتجها إلى إقرار تطبيق القو انين الأصلح للمتهم بأثر رجعى بصورة عامـة ، حيث تنص الفقرة الأخيرة

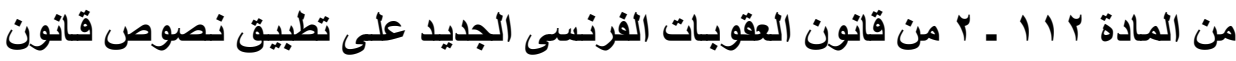

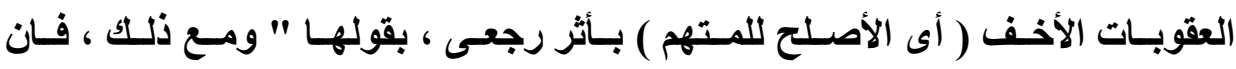
النصوص الجديدة تطبق على الجرائم المرتكبة قبل العمل بها ، والتى لم يتم الفصل فيها بحكم جاز قوة الأمر المقضى إذا كانت أقل شدة من النصوص القديمة " . وجدير بالذكر أن محكمة النقض المصرية اتجهت إلى المساواة بين القوانين المؤقتة بنص فيها والقو انين المؤقتة بطبيعتها من حيث عدم استفادة من يكون قد خالف أحكامها ـ فقضت بأن قرار وزير التموين الذى قضى بتخفيض وزن الرغيف لا يقصد به رعاية جانب أصحاب المخابز ولا التيسير عليهم و إنما تهذف الوزارة بإصداره إلى تحقيق اعتبارات اقتصادية بحتة تتصل بسياسة الحكومة، فلا تتأثر بهذا التعديل فى الوزن مصلحة لأصحاب المخابز بل يظل الوضع بالنسبة إليهم ثابتا سواء أكان هذا

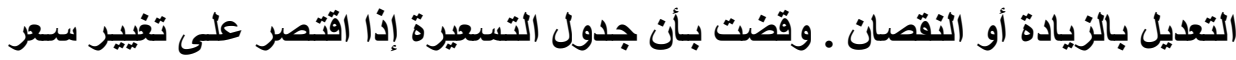

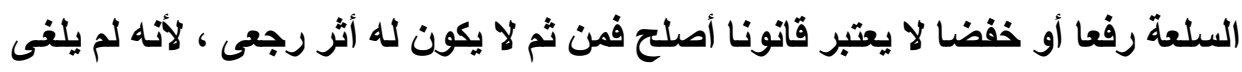

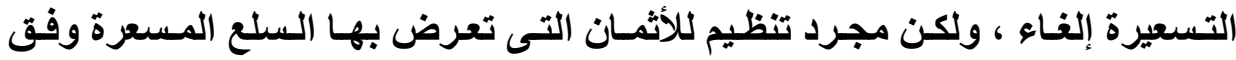

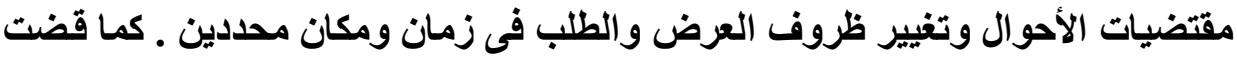
بأن القرار الخاص بتغيير مواصفات الردة لا يتحقى به معنى القانون الأصلح للمتهم فى في جريمة استخراج ردة معدة لرغيف العجين غير مطابقة للمواصفات ، لأن القرارات 
التموينية التى تحدد تلك المواصفات لا تعدو أن تكون من قبيل التنظيمات التى تمليها تلكك الظروف فى غير مساس بقاعدة التجريم أو العناصر القانونية للجريمة (') الخروج على هبدأ شخصية العقوبة : إن أكثر الوسائل فعالية فى تحقيق تثديد قسوة الجزاعات ، يتمثل فى الخروج

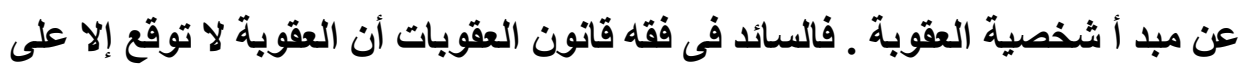

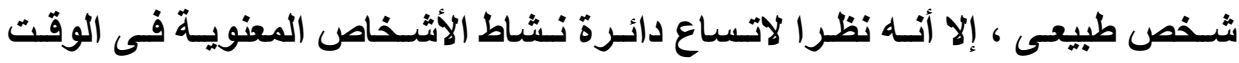

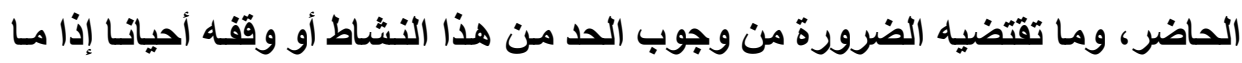
أصبح يشكل خطرا على أمن الجماعة ونظمها السائدة ـ فبان الراجح فى فقهـ قانون العقوبات الاقتصادى هو ضرورة توقيع الجزاء ليس فحسب على الثخص الطبيعى ، بل

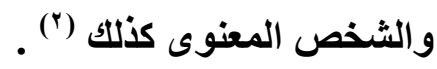

و هذا الخروج على المبادئ التقليدية أمر يقتضيه منطق الاقتصاد الموجهـ ـ ذلك

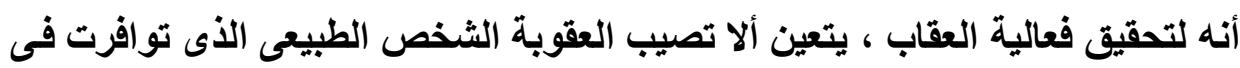

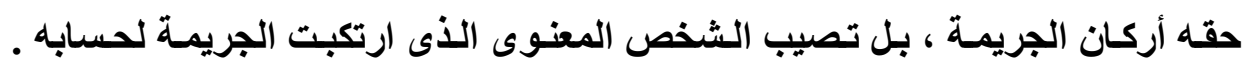

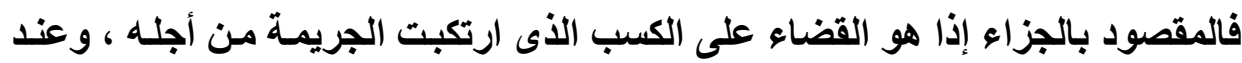

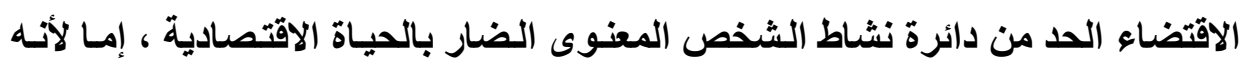

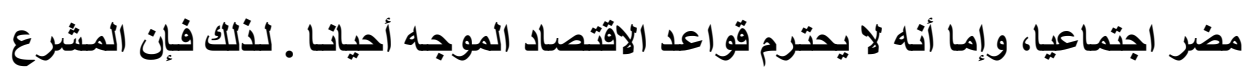

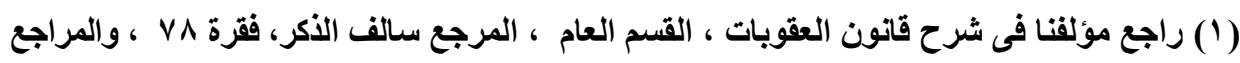

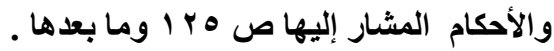

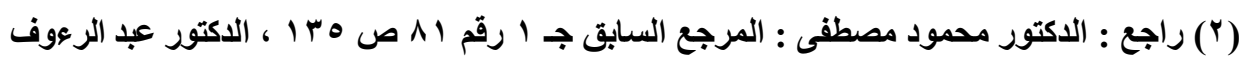

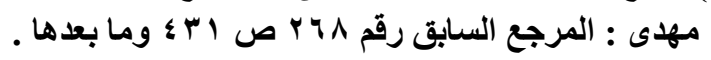
Merle et Vitu : Dr. Pén. Sp. Op. Cit., No. 747, P. 598. 
يخص الثخص المعنوى بنوع خاص من العقوبات ، وهى العقوبات المالية ، والغرامـة، وغالبا ما تكون شديدة ، وقد ترتفع إلى حد كبير فى بعض الجرائم ، وهذه الغرامسات ليست إلا ثمنا للخطر الاقتصادى المقدر من قبل الثخص المعنوى (') ـ على أن التطبيق العملى أثبت أن غلق المنشأة عقوبة فعالة فى إزالة الاضطراب الذى أحدثته الجريمـة ، ومنع تكرارها مستقبلا ، فضلا على أنها تحقق العدالة ، وتعيد التوازن بين المراكز الاقتصادية للمنشآت المتثابهة(؟). ولذلك تستعين كافة القوانين بالغلق لمكافحة الجرائم الاقتصادية ، والغلق قد يكون جزئيا أو كليا ، وقد يكون مؤقتا أو نهائيا (") . وغالبـا مـا يكون الغلق مقترنا بالحرمان من مزاولة النشاط الاقتصادى (؛) .

Ancel : Rapport préciteé, P. 855.

Léauté ( J. ) : Rapport Préciteé, P. 111.

$$
\begin{aligned}
& \text { الاكتور محمود مصطفى : المرجع السابق رقم ץ } 11 \text { ص VVI } 1 \text { وما بعدها . }
\end{aligned}
$$

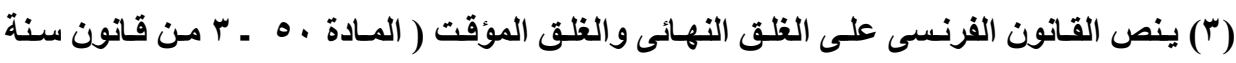

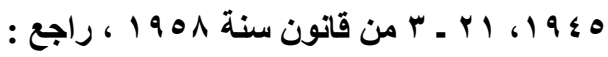

Merle et Vitu : Op. Cit., No. 748, P. 599.

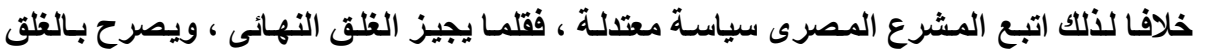
المؤقت لمدة قصيرة جدا بالقياس إلى المقرر فى القانون المقارن ، راجع الدكتئور محمود مصطقى :

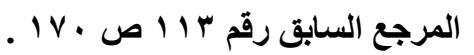

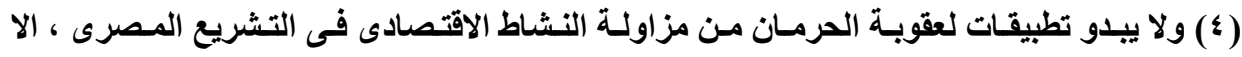

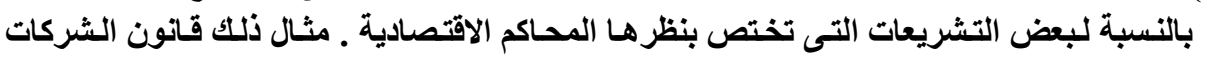

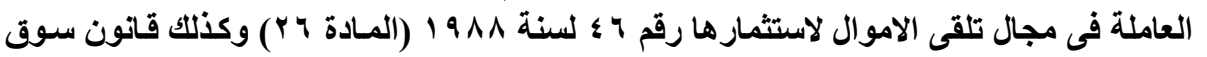

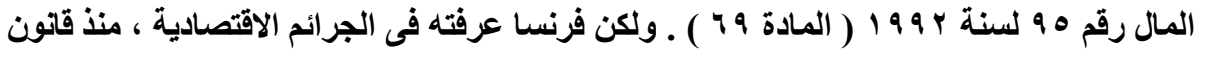

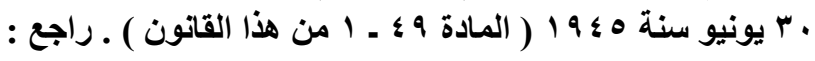

Merle et Vitu : OP. Cit., No. 748, P. 599. 
وعلى ذلك يتضح أن الجزاعات التى يخص بها القانون الشخصى المعنوى لا

تنطوى على فكرة التكفير أو التقويم كمـا هو الشأن فى العقوبـات التقليديـة ، وإنمـا الباعث عليها هو الوقاية أو الاحتياط حتى لا تقع الجريمـة فى المستقبل ، فهنالك حالة خطرة ، تبرر بـذاتها تطبيتى تـابير أمن حقيقيـه تهـف إلى الوقايـة أو الاحتيـاط مـن الثخص المعنوى ـ فحمايـة المجتمع تتطلب اللجوء إلى وسـائل وقائية يمكن توقيعها لمجرد استظهار الحالة الخطرة ( ) .

وفى الواقع أن الصفة الأساسية للجزاءات التى تتخذ قبل الشخص المعنوى ، والتـى لا يتحقتق فيهـا مبــأ شخـصية العقوبـة ، هـو إضـعاف ذمتـهـ الماليـة ، وعـدم

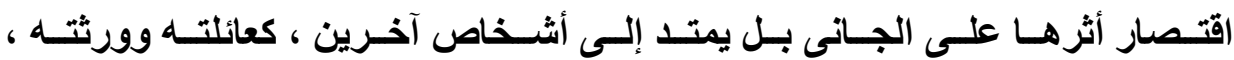
ودائنيـه ـ وهذه النتيجة خطيرة ، مسن وجهة النظر الاقتصادية ، خاصـة فى التـدبير الذى يمكن أن يؤدى إلى اختفـاء منشأة مفيدة للمجتمع ، بـالرغم مـن الأخطاء التى

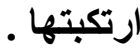

ويرى بعض الفقهاء ـ بحق ـ ضرورة الالتجاء إلى تقليل حجم المنشأة بـلا من غلقها ، وإذا كـان الغلق هو الوسيلة الوحيدة لمنـع تكرار الجريمـة ، فيكون ذلك فـى الجرائم الخطيرة ـ ولذلك تستعين كافة القوانين بالغلق لمكافحة الجرائم الاقتصادية ، فى سى نفس الوقت تقيده بما يارأ عيوبه(؟).

Ancel : Rappart Précité, P. 860.

Hémard ( J. ) : Rapport Précité, P. 551 ets. 


\section{الفرع الثانى \\ تعديل وظيفة العقوبة}

الجوي إلى الوظيفة التهديدية للعقوبة :

تعديل وظيفة العقوبـة يعد أشــ الآثـار الظـاهرة للتطورات التى لحقت قـانون

العقوبات على أثر تطور النظام العام الاقتصادى فى قانون العقوبـات ـ فبينمـا يبدو من المقرر ، لـدى غالبيـة الفقـه الجنـائى ، أن الوظيفـة المتميزة للعقوبـة يتعين أن تكون إصلاح المذنب ، إلا أن المشرع الاقتصادى ، تحت تأثير الاهتمام بفاعلية الجزاء ، اتجه ، إلى غرض ردع الأفراد (')

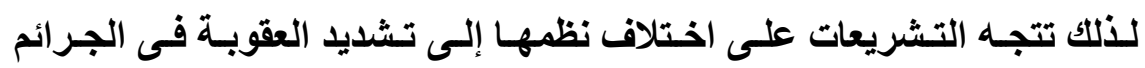
الاقتصادية ، ولا يسمح للقاضسى باستعمال وسـائل الرأفة المعروفة كوقف التنفيــ أو

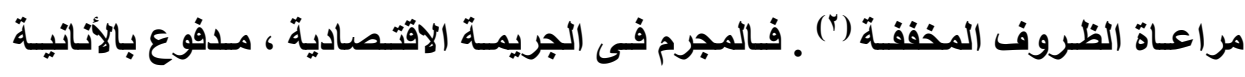
لتحقيق ربح غير مشروع ، يستهين بخطورة فعله بالنسبة للمجتمع ، فيلزم تخويفه بعقوبة رادعة .

وفضلا عن ذلك ، فإن التهايد بجزاعات رمزية من شـأنه تشجيع الكثيرين على ارتكاب الجريمة ، بينما التهديد بعقوبة جسيمة قد يدعو الكثيرين إلى التردد فى ارتكـاب

Ancel (M) : Rapport Précité, P. 856.

Merle et Vitu : Op. Cit. No. 742, P. 595 ets. 
الجريمة'( ) لذلك وجهت الأنظار نحو وظيفة حمايـة المجتمع ، الأمر الذى أدى إلى التضحية أحيانا بثخص المتهر .

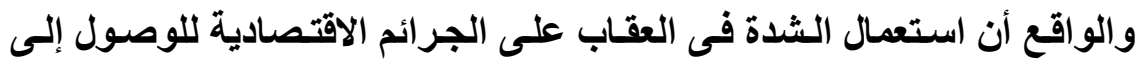

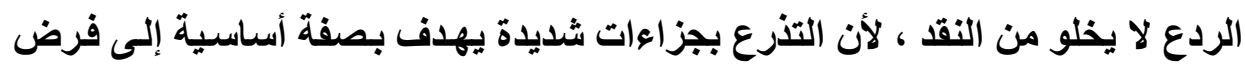

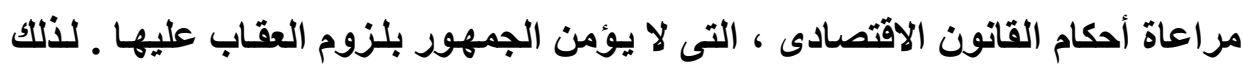

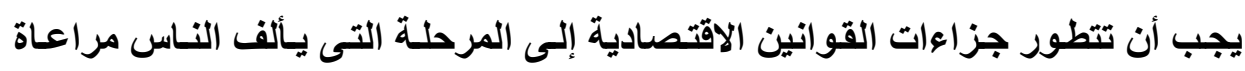

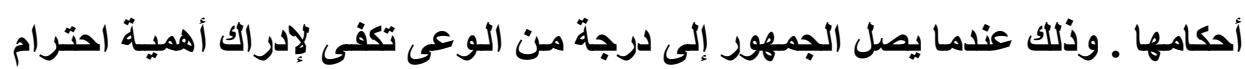

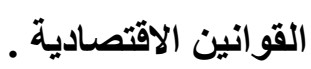

وإلى أن يحين ذلك يجب أن تتوسل التشريعات الاقتصادية فى ذلك باستعمال

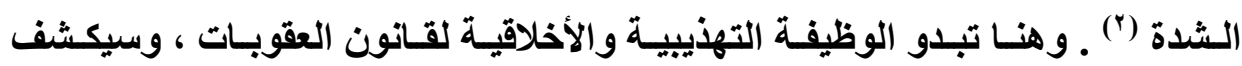

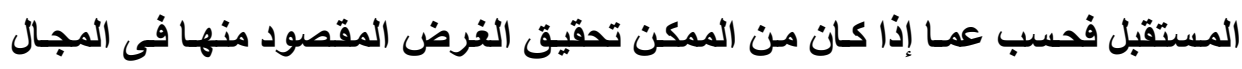

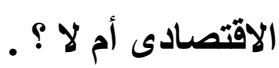




\section{المبحث الثالث \\ اتجاه السياسة الجنائية فى هبال النظام \\ العام الاقتصادى}

عرضــا فيمـا تقـــم تـأثثر الفكرة الجنائيـة للنظــام العـام فـى قـانون العقوبـات الاقتصادى على تطور القـانون الجنـائى ، والمبـادئ القانونيـة التى يقوم عليهـا ، ومـا صاحب ذلك من خروج عن المبادئ الأساسية فى القانون الجنائى . ونحن لا ندعى ، بهذا العرض ، أنتا يمكن أن نحدد هنـا مـا سيكون عليهه قانون العقوبات فى المستقبل الناتج من هذه التطورات التى سبق دراستها ، لأنه فضلا عن أن ذلك أمر قد يبلـغ حد الاستحالة لعدم تجميع نصوص قـانون العقوبـات الاقتصادى فى قانون خاص ، بـل هى مبعثرة فى ثنايـا القوانين الاقتصادية ، وبغير مراعاة للتنسيق بينها ـ فإن مثل هذا العدل يتجـاوز موضوع الاراسـة التى نحن بصددها ـ لـلك فإنتا سوف نكتفى باستخلاص الخطوط الأساسية التى تبلو فى الوقت الحالى بارزة من خلال السياسة الجنائية المتبعة بشأن حماية النظام العام الاقتصادى ل السياسة الجنائية بشأن حماية النظام العام الاقتصادى : يثار التساؤل هل وجود سياسة جنائية فى هذا المجال يفترض التحديد السابق لمـذهب معين ، أو على الأقل ، لأفكار عامـة موجهـة توجه الطرق العمليـة للعقـاب ؟

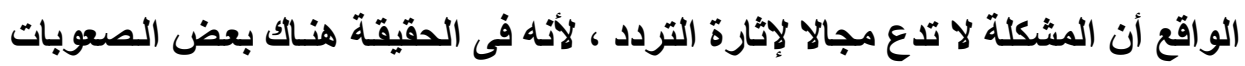
فى وضع إجابة محددة ، مجردة من الغموض والتعارض . 
إن عـدم وجـود سياسـة جنائيـة مرتبطـة بالنظـام العـام الاقتـــادى فى قـانون العقوبات ، يرجع بصفة طبيعية إلى عدم وجود نظام عام أساسى موجه. فالدولة تضطلع بوضع السياسة الاقتصادية أولا بـأول تحت تـأثير الأحداث وضرورات الحسال ، وتبعا لتطور الظروف ، دون مراعاة لسياسة واضحة فى التجريم أو التنسيق بين التدابير التى تضعها فى القوانين الاقتصادية (') ومن ثم فإن الدولة تلجأ إلى الجزاعات الجنائية استنادا إلى التدابير الموضوعة فى القوانين الاقتصادية ـ ويرجع ذلك فى الحقيقة إلى عدم وجود قانون خـاص للجرائم الاقتصادية ، بل أن المشرع يستعين بقانون العقوبـات فى تنفيذ القوانين الاقتصادية ، بمعنى يكتفى بـالنص على جزاءات جنائيسة تـدعيما لقوانين اقتصادية كشفت عنها التجـارب ، فأصبح القـانون نفعيا ، واتجهت التشريعات تحت تـأثير الاهتمسام بفاعلية الجزاء إلى تثديد العقوبة فى الجرائم الاقتصادية .

\section{إهكانية وحدة النظام العام الاتقصادى فى قانون العقوبات}

الواقع إن إدراج التدابير الاقتصادية فى القوانين الاقتصادية يمثل طابعـا خاصسا سياسيا واجتماعيا ، لأنها لا تصدر إلا فى ظروف عارضة وتنتهى بزوال هذه الظروف . ويبدو ذلك فى التذرع بجزاعات شـيدة عن الاعتداءات التى تقع على النظـام العـام

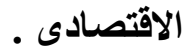

ومما لا شك فيه أن ذلك لم يكن وليد الصدفة ، ذلك أن بداية هذه الظاهرة يطابق اتجـاه السياسة الاقتصادية ، التى اتخذتها كثير من الدول ، نحو الزيـادة من التدابير

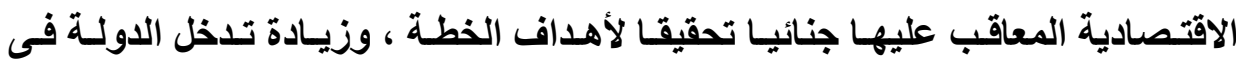


مختلف النواحى الاقتصادية تحقيقا لفعالية الخطة فى تحقيق الأهداف التى يرد تحقيقها .

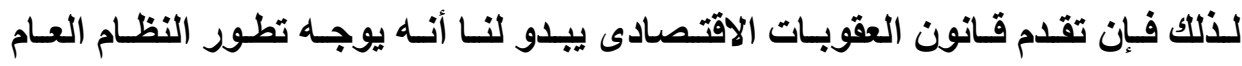
الاقتصادى فى قانون العقوبات نحو وحدة كبيرة .

ومما لا شكك فيه أيضا أن إعادة تنظيم الهياكل الاقتصادية والإدارية والاجتماعية للاولـة ، لتحقيـق التخطيط ، سـيجعل مـن الـضرورى إصـدار قـانون خـاص للجـرائم الاقتصادية لأجل طويل أو قصير تبعا للخطة ـ ذلك أن قانون العقوبات الاقتصادى عندما يتجاوز مرحلة التكوين المضطربة ، التى يكتفى فيها بنصوص مبعثرة فى ثنايا القوانين

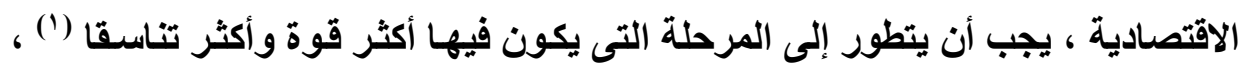
والبحث فى قواعده وأحكامه وإمكانية استقلاله (ץ) ــ والواقع من الأمر أن التطور الجديد الأى ظهر عليه قانون العقوبات الاقتصادى يسمح له بأن يتطور على أسس ثابتة ترتبط بأسسس السياسة الاقتصادية الثابتـة ، وذلك بغرض إقامـة " صسورة جنائيسة حقيقيـة

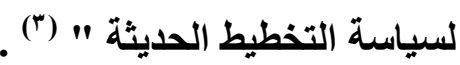

Bouzat ( P. ) Aspects et Problémes juridiques de la Planification (Droit Pénal ) Rapport aux VIII journeés juridiques, franco - yougoslaves (Belgrad Novi- sad, 13 - 27 mai 1965 ), Société de législation comparée, 1965. P. 21 ets.

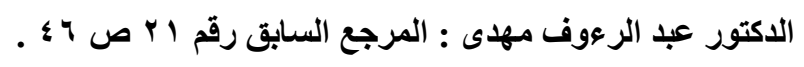

Ancel (M) : Rapport Précité, P. 853.

مجلتً البحوث القانونيت والإقتصاديت 


\section{خـــــاتمة}

خصصنا هذا البحث للتطورات الاقتصادية المعاصرة واثرها على تطور القانون الجنائى ، والمبادئ القانونية التى يقوم عليها ، وما صاحب ذلك من خروج عن المبادئ الأساسية فى القانون الجنائى . وقد أسفر البحث عن نتائج ، ينبخى أن نبرزهـا فى هذا

- رأينـا أن قانون العقوبـات التقليدى يحمى من قديم ، وعلى نطاق واسـع مصالح المجتمع ـ إلا أن الضرورات الجديدة التى أهتم بها المشرع الاقتصادى أظهرت

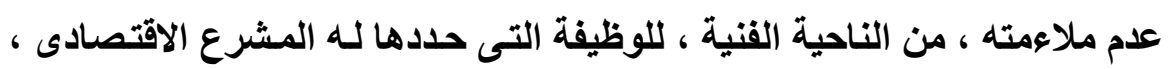
باعتباره وسيلة حماية المصالح الاقتصادية الجماعية ـ وقد تبين لنا أن عدم ثبات النظام العام الاقتصادى ، واتسام أغلب نصوصه "بالصناعية " ، وعدم الأخلاق ، لا يتفق مع قسوة المبادئ التى يفرضها الجزاء الجنائى فى الجرائم الكلاسيكية . ـ كما شملت التحولات فى أحكام الجريمة الاقتصادية قواعد الإجراعات الخاصـة بها أيضا ـ ففى المفهوم التقليدى للاعوى الجنائية يبدو الصراع بين المتهم والنيابة العامة باعتبار ها ممثلة المجتمـع ، وكانت القواعد تهدف إلى إعـادة التوازن بين القوى المتصارعة ـ بينما الاعوى الجنائية فى الجرائم الاقتصادية أصبح الصراع ثلاثيا ، فقد عهدت الدولة إلى النيابة العامة جزء من التفويض الذى عهد بـه إليها المجتمع ، لتدافع عن مفهومها الخاص عن المصلحة العامة أمام القاضسى الجنـائى • ولذلك استقلت الدعوى الجنائية فى الجرائم الاقتصادية بأحكام خاصة ، ليس فقط

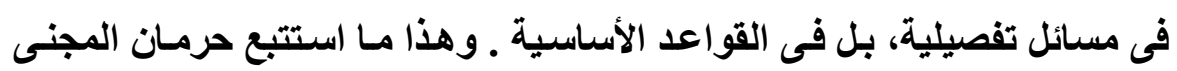
عليه من تحريك الاعوى الجنائية . 
ـ وتبين لنا من خلال التطورات التى لحقت الأحكام العامة فى قانون العقوبات ، أن

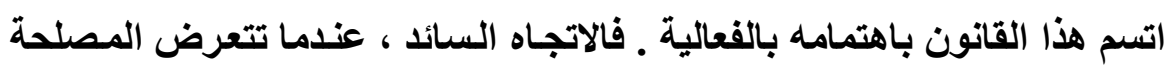

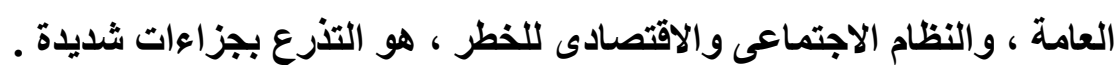
- وقد لـوحظ أن السياسة الجنائيسة فـى الجرائم الاقتصادية تــتأثر بتقلبـات النظـام

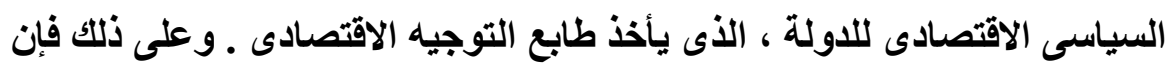

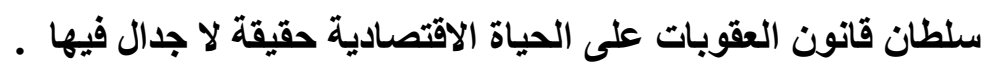
- والخلاصة أن من أهم مظاهر قانون العقوبـات فى العصر الحديث، بوصفه حاميا

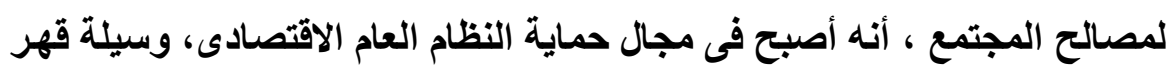
أو ضغط أو إكراه تتوسل به الدولة لحماية سياستها الاقتصادية. 


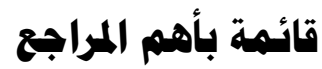

\section{أولا : بالاغة العربية :

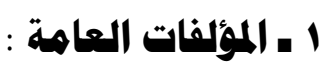 \\ أ ـ ـ ـ أحمد فتحى سرور :}

ـ الوسبط فى قانون العقوبات ـ القسم الخاصه 191 ـ

ـ الوسيط فى قانون العقوبـات ـ القسم الخـاص (الجرائم المضرة بالمصلحة

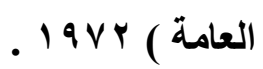

أ ـ جندى عبد الملك : أ

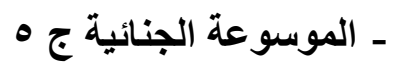

أ ـ د ـ ـ روف صادق عبيد :

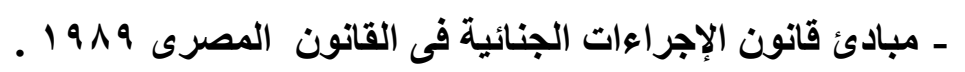

$$
\text { المستشار دـ ـ عبد الرزاق السنهورى : }
$$

ـ الوسيط فى شرح القانون المدنى المجلد الأول ط ـ19 1 .

$$
\text { أ ـ د. ـ عبد القتاح عبد الباقى : }
$$

ـ موسـوعة القـانون المـدنى المـصرية ( نظريــة العقدـ والإدارة المنفـردة)

$$
.191 \varepsilon
$$

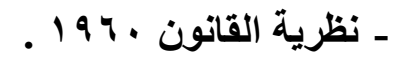




$$
\text { أ ـ ـد ـ محمد عيد الغريب : }
$$

ـ شرح قانون العقوبات القسم العام ط . . . . . .

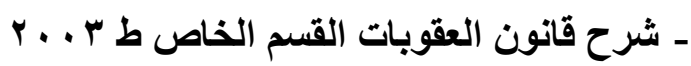

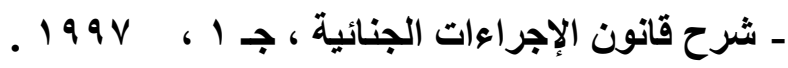

$$
\text { أ ـ د. ـ محمود نجيب حسنى : }
$$

ـ ش شرح قانون الاجراءات الجنائية r 19 r

ـ شرح قانون العقوبات ـ القسم العام ـ ـ 99 ـ ـ

أ ـ د ـ محمود مصطفى :

ـ شرح قانون العقوبات القسم العام ع 9 ـ

r ـ المؤلفات الخاصة والراسائل والأبحاث والتعليقات :

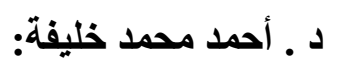

ـ النظرية العامة للتجريم - رسالة دكتوراه القاهرة 9 ـه 19.

$$
\text { ا ـ د ـ آمال عبد الرحيم عثمان : }
$$

ـ الخبرة فى المسائل الجنائية ، رسالة دكتوراه القاهرة ؛ 9 أ 1 ـ

$$
\text { أ ـ د ـ عبد الرعوف مهذى : }
$$

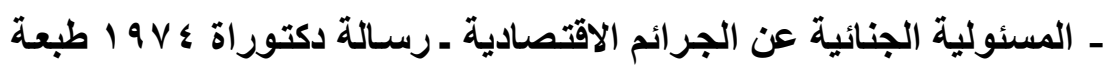




$$
\text { أ ـ د ـ فتحى عبد الرحيم عبد الله : }
$$

ـ العناصر المكونة للعقد كمصدر للالتزام فى القانونين المصرى والإنجليزى المقارن ، مجموعة البحوث القانونيـة والاقتصادية كلية حقوق المنصورة $.19 \vee 9$

$$
\text { أ ـ د ـ محمود مصطفى: }
$$

ـ الجرائم الاقتصادية فى القـانون المقـارن جـا الأحكـام العامـة والإجراعات

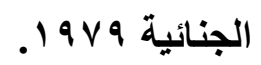

ـ تعليق على موضـوعات المـؤتمر الـدولى الثالث عشر لقـانون العقوبـات

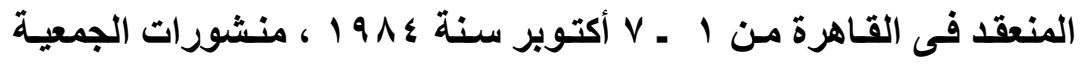

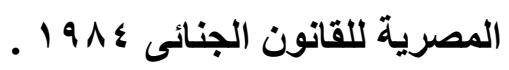

\section{ثانيا : بالاغة الفرنسية}

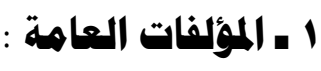

Bouzat ( P. ) et Pinatel ( J. ) :- Traité de Droit Pénal et de criminologie, 2 éd. Dalloz. T 1, 1968.

Carbonnier ( J. ) :- Droit Civil, Coll. Thémis, Tome 11, et v, 1979, P. u. f.

Merle ( R. ) et Vitu ( A. ) :

- Traité de Droit Criminel, Cujas, T. 1, 3 éd. 1978. T. 11, 3 ed. 1979. 
-Traité de .. Droit Pénal, Special, par Vitu, T. 1 et T. 11, 1982.

Stéfani ( G. ) levasseur et Bouloc :

- Droit Pénal géneral Dalloz 1980.

-Procédure Pénale, Dalloz 1984.

r ـ المؤلفات الخاصة والرسائل :

Farjat ( M.M.G. ) : l’ordre Publique éconimique Thése, Dijon, 1963.

Levasseur ( G. ) : le droit Pénal économique, cours de doctrat, le caire 1960- 1961.

Ottenhof ( R. ) : le droit Pénal et la Fotrmation du contrat civil, th. Rennes 1970 .

\section{rـ الأبحاث والاقالات والتقارير :}

Ancel (M.) : les sanctions en matiére de droit Pénal économique, in Rapports généraux au 5 éme congrés int. de dr. comp., Bruxelles 1960 .

Bouzat (P.) : Aspects et Problémes juridiques de la Planification (Droit Pénal) Rapport aux VIll journeés juridiques, franco - yougoslaves ( Belgrad Novi- sad, 13 - 27 mai 1965 ), Société de législation comparée, 1965. 
Costa (J. L.) : La jurisprudence de la chambre criminelle et L'élabration d'un ordre Public économique et social, in la chmbre criminelle et sa jurisprudence ; Recueil d'etudes en hommage à La mémoire de Maurice Patin, Cujas 1965.

- Rapport Sur la rôle du juge en Présence des Problémes écinomiques en Droit Pénal Francais, in trav. De l'asso. H. Capitant, T. XXIl, 1970.

Delmas Marty (M.) : Rendre la droit Pénal des affaires Plus dissuasif, Rev. Dr. Pén. Et de crim. 1981

Fonyo (A.) et Vermes (M.) : L'économie et le droit, Aspects de droit Pénal, Rapport Présenté aux deuxiémes journeés juridiques, franco-hongroises, Paris ler au 5 Juin 1970, Publie in Rev. Sc. crim. 1974 No. 1.

Guilberteau (Mme) : la recevablité de l'action Syndicale en matiére d'infraction économiques, Rev. Sc. Crim. 1973.

Hartemann (luc) : L'action civile et les infractions à la Législation économique apers La Loi Royer. Rev. Sc. Crim. 1976.

Larguier (J.) : L' action Publique menacée, D. 1958, chron. 
Léauté (J.) : Rapport général sur les infractions économiques, Trav. De L'asso H. Capitant, T. XIII, 1963.

Levasseur (G.) : -Rapport général, in journeés de Paris et Montepllier, le rôle du juge en présence des problémes économiques, Trav. De L'asso. H. capitant, T. XXII, 1970.

Mazard (J.) : Aspect du Droit économique francais (Autonomie et orthoxie ), Rev. Sc. Crim. 1957.

Pierre Henri Belle : La lutte contre la crininalite économiques en auisse, Rev. Pén. Suisse, No. 2, 1981.

Pirovano (A. ) : Lo concurrence déloyale en droit français, in Marché concurrence et consommateurs, Rev. int. dr. comp. 1974.

Savatire (R. ) : -L’ordre Public économique D. 1965, Chron.

Stefani (G.) :- quelques aspects de L' autonomie de droit pénal 1956 préface . 